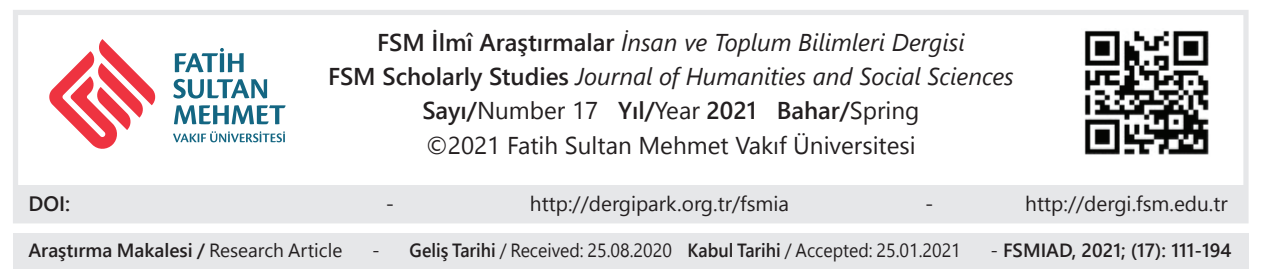

\title{
Bir Büyük Selçuklu Dönemi Şaheseri Ardistân Cuma Camii Alçı Süsleme ve Kitabeleri ${ }^{12}$
}

Kamran Sokhanpardaz

\section{Öz}

İslam mimarisinde en önemli dini yapı türü sayılan camiler, Büyük Selçuklu döneminde zengin alçı süslemeler barındırmıştır. Böylece İran İslam sanatının altın çağ 1 olarak bilinen Büyük Selçuklu dönemi, her sanattan daha çok, alçı süsleme sanatında geriye şaheserler bırakmıştır. Bundan hareketle bu makalede, Büyük Selçuklu dönemi şaheserlerinden sayılan Ardistân Cuma Camii Mimarisi ve onun alçı süsleme ve kitabeleri ele alınmıştır. Elde edilen sonuçlardan, yapıda Büyük Selçuklu dönemine ait alçı süslemeler, yapının farklı bölümlerinde bulunup, süsleme kompozisyonunun, yazı, bitkisel ve hendesi bezemeleri içerdiği ve kazıma, kabartma ve kalıplama tekniğinde yapıldıkları anlaşılmaktadır. Bu yapıda işlenmiş alçı süslemeler Büyük Selçuklu döneminden önce ve sonraki dönemlere ait süsleme örnekleri ile yakın benzerlik arz etmektedir. Daha önce yapılan birçok araştırmada, yapının Büyük Selçuklu döneminde tek eyvanlı olup, sonraki dönemlerde dört eyvanlı hale getirildiği iddia edilmesine rağmen, caminin iç mekânındaki kitabeden elde edilen bilgiler dikkate alındığında, yapının Büyük Selçuklu döneminde dört eyvanlı olarak inşa edildiği bu çalışma kapsamında tespit edilmiştir.

Anahtar Kelimeler: Büyük Selçuklu, cami, mimari, Ardistân Cuma Camii, alçı süsleme.

1 Bu makale doktora tezinden faydalanılarak hazırlanmıştır.

2 Bu çalışma Ondokuz Mayıs Üniversitesi BAP tarafından desteklenmiştir (Proje No: PYO. ILH.1904.18.001).

* Dr., Ondokuz Mayıs Üniversitesi, Samsun/Türkiye, artresercher@gmail.com, orcid.org/00000002-5247-1731 


\title{
Stucco Ornaments and Inscriptions of the Great Mosque of Ardestan as One of the Masterpieces of the Great Seljuk Period
}

\begin{abstract}
the mosques are considered to be the most important religious building type in Islamic architecture. The mosques had rich stucco ornaments during the Great Seljuk period. From the Great Seljuk period, known as the golden age of Iranian Islamic art, remains masterpieces in the art of stucco decoration more than any other art kind. In this article, the architecture of the great mosque of Ardestan, which is considered as one of the masterpieces of the Great Seljuk Period, and also its stucco ornaments and inscriptions are discussed. According to the results, the stucco decorations in these mosques include inscriptions, vegetal and geometric decorations made using embossing, engraving, and stamping techniques. The stucco ornaments of this mosque are similar to the ornaments of periods before and after the Great Seljuk era. Although it was claimed in many previous studies that the building had a single porch during the Great Seljuk period and was transformed into four porches in the following periods, considering the information obtained from the inscription in the interior of the mosque, was determined that this mosque was built in the form of four porches during the Great Seljuk period.
\end{abstract}

Keywords: Great Seljuk, mosque, architecture, Great Mosque of Ardestan, stucco ornament. 


\section{Giriş $^{3}$}

İran mimarisinde, Râzî (رازى) ${ }^{4}$ üslubu diye adlandırılan üslup, ilk olarak Curcan'da başlamış ve Büyük Selçukluların ilk başkenti olan Rey şehrinde geliştirilerek son halini bulmuştur. Selçuklu yönetimi İran, Anadolu ve Irak bölgelerinde bulunan sanatı himaye altına alarak, sanatın ve mimarinin gelişimine imkan sağlamış ve kendilerine özel bir sanat ve mimarlık uslûbu oluşturmuşlardır. $\mathrm{Bu}$ coğrafyada tarih boyunca, tuğla ve alçı, yap1 ve süsleme ${ }^{5}$ malzemesi olarak kullanılmıştır. İslam'dan önceki dönemlerde, eski Mısır ve Mezopotamya'da da mimaride tuğla ve alçı en önemli yapı ve süsleme malzemesi olarak ele alınmıştır.

Büyük Selçuklu öncesi İslam dönemi (Gazneliler dönemine kadar) İran mimarisinde, yapıların iç ve dış yüzeylerinde alçı yoğun olarak kullanılırken, ${ }^{6} \mathrm{X}$. yüzyıldan sonra daha çok iç dekorasyon malzemesi olmuştur. $\mathrm{Bu}$ döneme ait alçı süslemelerin daha çok İslîmî ${ }^{7}$ şeklinde tasarlandığı görülmektedir. İlhanlı dönemine gelindiğinde alçı süslemelerin, Büyük Selçuklu geleneğini devam ettirdiği görülmektedir. Başka bir deyişle Büyük Selçuklu alçı işçiliğinin, İlhanlı alçı bezemesinin temelini oluşturduğu ileri sürülür. ${ }^{8}$ Örneğin Hemedan' da XII. yüzyılın ikinci yarısında inşa edilen Kümbed-i Aleviyan'ın süslemeleri, Ardistân

3 Kısaltmalar: Bkz.: Bakınız / H.Ş: Hicri Şemsi.

4 Farsçada Râzî / راز kelimesi, Rey şehrine mensub demektir (Bkz.: Ali Ekber Deh-hudâ, Lugatnâme, cilt VIII, Tahran, Müessese-i İntişarat ve Çap-i Danişgâh-i Tahran, 1377 H.Ş, s. 11704).

5 Süsleme kelimesinin Arapça karşıllğı olan tezyinat'ın kökü olan ziynet'in “zenginliğin göstergesi olan eşya” anlamına gelmektedir. (Bkz: Selçuk Mülayim, Değişimin Tanıkları: Ortaçă̆ Türk Sanatında Süsleme ve İkonografi, İstanbul, Kaknüs Yayınları, 1999, s. 17.)

6 Bkz.: Celal Esad Arseven, “Alçı”, Sanat Ansiklopedisi, cilt I, İstanbul, 1983, s. 38.

7 "İslâmi”" kelimesi "İmâle” veya "mümal” (Kısma) denilen aruz kuralı uygulanması sonucunda "İslîmî" şeklini almıştır. ("İmâle" veya "mümal”, uzun bir heceyi, kısa yapmaya denir. (Bkz.: Ahmad Sadr Hâc Seyid Cavâdi, Dâyirat al-meârif-i Tashayyu, cilt II, Tahran, Bunyâd-i İslâmi-i Ṭâhir, 1365 H.Ş, s. 162.; Muhemmed Muin, Ferheng-i Farsi Mutavassit, Silsila-i Farhangha-yi Muin, cilt I, Tahran, Emir Kebir, 1386 H.Ş, s. 273.; Muhammed Nahvi, Ferheng-i Rişei-i Vam-vajehay-i Arabi, Tahran, İntishârât-i İslâmi, 1386 H.Ş, s. 196.; Necmeddîn Dâye Râzî, Mirsâdü'l-ibâd, Tahran, Bungâh-i Tercume ve Neşr-i Kitâb, 1351 H.Ş, s. 107.) İslimi kelimesinin en erken örneği, 15. yüzyıla ait, Cafer Baysunguri tarafından hazırlanmış Cöng-i Yakûbî nüshasının "Arza-dâşt” bölümünde bulunmaktadır. (Bkz.: Şihâbüddîn Abdullah b. Lutfillâh b. Abdirreşîd-i Bihdâdînî-yi Hâfî Hâfız-1 Ebrû, Zübdetü’t Tevârîh, Tahran, Vezaret-i İrşâd-1 İslâmî, 1380 H.Ş, s. 969.; M. Kemal Özergin, “Temürlü Sanatına Ait Eski Bir Belge: Tebrizli Cafer'in Bir Arzı”, Sanat Tarihi Yıllı̆̆g, S.6, İstanbul, 1976, s.491, 494.)

8 Arthur Upham Pope, Mimari-yi İran, çev. Golamhüseyn Sadri, Neşr-i Enzeli, Urumîye, 1363 H.Ş, s. 156. 
ve Zevvare Ulu camilerindeki ${ }^{9}$ örnekleri takip etmektedir. ${ }^{10}$ Dolayısıyla Safeviler de İlhanlılar başta olmak üzere Timurlu mimari eserlerinde kullanılan alçı süslemeleri örnek almak suretiyle dolaylı olarak Büyük Selçukluları izleyerek kendi üsluplarını oluşturulmuşlardır. Büyük Selçuklu döneminde alçı işçiliği de diğer sanatlar gibi gelişme göstermiştir. Bundan hareketle bu makalede, Büyük Selçuklu dönemi şaheserlerinden sayılan Ardistân Cuma Camii'nin mimarisi ve onun alçı süslemeleri ile kitabeleri ele alınmıştır.

\section{Genel Tanım}

Ardistân şehri, İran'ın İsfahan Eyaleti'nin kuzeyinde yer almaktadır. Ardistân'da Selçuklular devrinden kalan en önemli eser Ardistân Cuma Camiidir (Resim 57). Yapının diğer adları, Ardistân Ulu Camii ve Mescid-i Cami-i Ardistân'dır. Yap1, Ardistân'ın şehir merkezinde Mehâl mahallesinde (Gps Koordinatı : 33.374501, 52.365658) bulunup, İran Milli Eserler Listesinde 180 numarada kayıtlıdır. 1974-1978 yılların arasında Dr. Baker Âyetullâh Zadeh Şirazi’nin yaptığı arkeolojik kazı ve araştırmalarının sonucunda inşası Büyük Selçuklu döneminde tamamlanan eserin temelinin ${ }^{11}$ I-IV asırlara dayandığ ileri sürülmüştür. Dr. Şirazi yapının Büyük Selçuklu döneminden önce, kare planlı, kubbesiz ve çok sütunlu olduğunu kaydetmektedir. ${ }^{12}$ Yapılan birçok araştırmada güney eyvanın dışındaki diğer üç eyvanın süslemelerine bakılarak, yapının Selçuklu döneminde tek eyvanlı olup, sonraki dönemlerde dört eyvanlı hale getirildiği iddia edilmektedir. Fakat caminin iç mekânındaki kitabeden elde edilen bilgiler dikkate alındığında bu iddianın tutarsız olduğu düşünülmektedir. Zira söz konusu kitabede ana eyvanın üzerindeki kubbe ile, ona bitişik olan dört kubbenin ve önündeki eyvanların inşasının 555/1160 yılında gerçekleştiği ifade edilmektedir. ${ }^{13}$ Mevcut kitabelere

9 Shani Raya, "Stucco Decoration in the Gunbad-i Alewiyyan at Hamadan", The Art of Seljuqs in Iran and Anatolia, ed. R. Hillenbrand, Costa Mesa, 1994, s. 72.

10 Maurice Sven Dimand, A Handbook of Mohammedan Decorative Arts, New York, Metropolitan Museum of Art, 1930, s. 98.

11 Muhammed Yusuf Keyani, Tarihi Hunar-i Mimari-i Iran der Devre-i İslami, Tahran, Semt, 1379 H.Ş, s. 44.

12 Baker Âyetullâh Zadeh Şirazi, "Mescid-i Cami-i Ardistân”, Eser, cilt I, S. I, Tahran, Sazman-i Miras-i Ferhengi Senayi-i Desti ve Gerdişgeri, 1359 H.Ş, s. 6-51.

13 Konuyla ilgili şunu belirtmek gerekir ki Arapça'da "ات” çoğul eki olarak, eklendikleri kelimelerin sayı bakımından üç veya daha fazla olduğunu belirtir. Bu yüzden kitabede eyvanlar anlamına gelen الصُّفّات (Suffât) kelimesinin sonundaki ekten hareketle, caminin en az üç eyvanlı formunu Büyük Selçuklular döneminde aldığını söylemek mümkündür. Ayrıca güney eyvanın dışındaki diğer üç eyvanın süslemelerine bakılarak, yapının daha sonradan dört eyvanlı hale getirildiği şeklindeki açıklamalar da makul görünmemektedir. Nitekim 1984 yılında Sheila 
göre caminin banisi Ebû Tâhir el-Hüseyn b. Gālî b. Ahmed (ابوطاهر الحسين ابن غالى) (ابن احمد), mimarı ise Mahmûd b. Muhammed el-Benna (محمود بن محمد البنّا) olduğu bilinmektedir. ${ }^{14}$ Ardistân Cuma Camii $69.00 \times 52.00$ m boyutlarında bir alana oturmaktadır. Kuzey-güney doğrultusunda uzanan cami, dıştan düzgün olmayan dikdörtgen planlı, avlulu, dört eyvanlı ve mihrap önü kubbeli bir yapıdır (Plan 1). Caminin sekizgen kasnak üzerine oturan ana kubbesi çift cidarlıdır. Kubbe eteğinde ve kubbe kasnağında aydınlatma amaçlı dörder dikdörtgen açıklık yer almaktadır. Caminin farklı yerlerinde Büyük Selçuklu döneminden önceki ve sonraki dönemlere ait süslemeler bulunmaktadır.

Caminin avlusu dikdörtgen planlıdır. Güney-doğu, güney-bat1, kuzey-doğu, kuzey-batı köşeleriyle doğu ve kuzey yönlerinde olmak üzere camiye giriş çıkış için toplam altı kapı bulunmaktadır. Bunlardan üçü kapatılmıştır. Günümüzde asıl giriş, doğu cephedeki kapıdan sağlanmaktadır. Yapıda bulunan revaklar çift katlı olarak tasarlanmıştır. Caminin avlusunda zemin katta daha önce araştırmacılar tarafından bahsedilmemiş, fakat yeni çıkan haritalarda görülebilen gizli bir bölüm yer almaktadır. Söz konusu bölüm, iki mihrabı bulunan dikdörtgen bir alandan oluşmaktadır. Bu alana giriş-çıkışın yasak olması nedeniyle fazla bilgi elde etmek mümkün olamamıştır.

Camiinin tuğla malzemeden yapılan silindirik minaresi kuzey-batı köşesinde yer almaktadır. Kubbeli mekân ile onun doğusunda toplam üç alçı mihrap bulunmaktadır. Asıl mihrap, kıble duvarının ortasında yer alır. Caminin kuzey eyvanında bulunan Nesta'lik karakterli 946/1540 tarihli kitabeye göre, yapı I. Şah Tahmasb ${ }^{15}$ zamanında onarım görmüştür. Güney eyvanında kubbeli mekâna girişi sağlayan kemer açıklığının sağ tarafındaki Nasta'lik hatla yazılmış 1024/1615

Blair ve Jonathan Bloom'un çektikleri fotoğraflardan Kirman Melik Camii eyvan süslemelerinin Safevi dönemine ait olduğunu söyleyebilmekteyiz. Ayrıca 1989 yılında yaşanan depremden dolayı, camiin ana eyvanının üzerindeki süslemeler dökülmüş, altından Büyük Selçuklu dönemine ait süslemeler ve kitabeler ortaya çıkmıştır. Bu bilgiler ışığında, yapının Büyük Selçuklular döneminde iki aşamada dört eyvanlı hale getirildiğini düşünmekteyiz. Nitekim mihrap önünde beden duvarları üzerinde ve güney eyvandaki tonoz örtünün eteğinde bulunan kitabelerden aynı kanaate ulaşmak mümkündür. Buna göre birinci aşamada (553/1158 tarihte) kubbelerle önündeki sofaların (eyvanların) yapıldığı; ikinci aşamada (555/1160 tarihte) ise güney eyvanı ile sağdan ve soldan bitişen revakların ilave edildiği sonraki dönemlerde ise yapıya sadece kitabe ve süslemelerin eklendiği söylenebilir.

14 Gâzi diye ün yapmış üstad Mahmud İsfahânî (استاد محمود اصفهانى الغازى)

15 I. Şah Tahmasb, I. Şah İsmail'in oğludur. Safevî Devleti'nin ikinci ve en uzun süre yönetimde kalan hükümdarıdır. 
tarihli kitabe ise I. Şah Abbas' $1 n^{16}$ fermanın1 17 içermektedir. Ardistân Cuma Camii’nin yanında, Hüseyniye, Medrese-i İlmiye ${ }^{18}$, kervansaray, çarş1, ve su deposu gibi çeşitli tarihi binalar bulunmaktadır. ${ }^{19}$ Cami günümüzde ibadete açıktır.

\section{Alçı Süslemelerin Bulunduğu Yerler}

Yapıda büyük Selçuklu dönemine ait alçı süslemelerin bulunduğu yerler: IMihraplar, II- Kubbeli mekânda beden duvarlarının üzerini dolanan yazı kuşağı, III- Kubbeli mekânda kemer karınları, IV- Tromplar ile ara yüzeylerdeki nişler, V- Kubbeli mekânda beden duvarları üzerinde bulunan nişler, VI- Kubbeli mekâna girişi sağlayan kemerin karnı, VII- Güney eyvan doğu, batı ve güney duvarların üst kısımları ve sivri tonoz örtünün eteği, VIII- Güney eyvana girişi sağlayan kemerin karnı ve IX- Kubbeli mekân ve güney eyvandaki tuğlaların arasındaki derzler.

\section{Alçı Süslemelerin Kompozisyon Özellikleri}

Ardistân Cuma Camii'nin asıl mihrabı, kıble duvarının ortasında 7.00×4.40 m. ölçülerinde olup, iki bordür (iki çerçeve), iki sivri kemer, dört sütunce ve iç içe iki mihrap kurgusu içermektedir (Resim 1; Çizim 1). Tarih kısmının, mihrabın bozulmuş alt kısmında bulunduğu düşünülmektedir. Mihrabın bordürlerini birbirlerinden ayıran kademeli tuğla silmeler, 1ş1k-gölge etkisiyle dikkat çeker. Mihrapta dıştan içe doğru düz yüzeyli birinci bordürde, kabartma tekniğinde ve bitkisel ${ }^{20}$ süslemeli zemin üzerinde işlenmiş tezyinî ve müşeccer kûfi yazı karakterli

16 I. Şah Abbas Safevi Hanedanlığının beşinci ve en güçlü hükümdarıdır.

17 Kitabede I. Şah Abbas'ın Ardistân Şiilerine vergi indiriminden bahsedilmektedir.

18 Medrise-i İlmiye İran'ın dini okullarına verilen genel adıdır.

19 Muhammed Yusuf Keyani, İslam Dönemi İran Mimarisi, çev. Kaan Dilek, Muhammet Atmaca, ed. Afsun Nikrevan, I. bs., Ankara, Kültür Bakanlığı, 2018, s. 44-45.

$20 \mathrm{Bu}$ çalışmada rumi motifi, bitkisel süsleme gurubuna dahil edilmiştir. Farsça araştırmalarda, İran sanatında sıkça kullanılan rumi motifi bitkisel bir motif olarak kabul edilmiştir. "Tezyin-i giyâhi / تزيين كياهـ"; bitkisel süsleme anlamına gelmekle birlikte, Farsça araştırmalarda islîmî, rumi ve hatâyî gibi motifler, bitkisel süsleme olarak adlandırılmıştır (örneğin Bkz.: Ahmad Salehi Kakhki, "Pezhuheşi Ber Tezyinat-i Mimari-i Devre-i Gaznevi”, Feslnâme-i Pezhhişhây-i Târihi, cilt IX, S. IV, Tahran, 1396 H.Ş, s. 91-118.; Elâhe Pencebâşi - Fatemeh Dulâb, "Mutalee-i Nakş Bercesti-hay-i Giyâhi Sirâf Der Devrei Sâsâni”, Cilve-i Hüner, cilt IX, S. II, Tahran, 1396 H.Ş, s. 21-38.; Vehid Hayder Nattaj - Mitra Maksudi, "Mukayese-i Tetbiki Mezamin-i Müşterek-i Giyâhân-i Mukaddes Der Nakşmâyehây-i Giyâhi-i Mimâri Piş Ez İslâm-i İran ve Ârâye-hây-i Mimari Devran-i İslâmi”, Băg-i Nazar, cilt XVI, S. LXXI, Tahran, 1398 H.Ş, s. 35-50.; Alireza Moshabaki İsfâhâni - Nergis Sefayi, "Berresi-i Tetbiki Giyâhân-i Mukaddes ve Üstûrei Der Hüner-i Sadr-i İslâm ve Piş Ez İslâm (Hehamenişi ve Sâsâni) Ba Tekid Ber Nakş Bercesti-ha”, Mimari-Şinasi, cilt II, S. XII, Tahran, 1398 H.Ş, s. 54-66). 
kitabede, Besmele, İsrâ suresinin 78-82. ayetleri ve "صدق اله العظيج ibaresi yer almaktadır ${ }^{21}\left(\right.$ Resim 2-3; Çizim 2) ${ }^{22}$ :

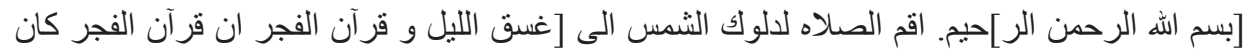

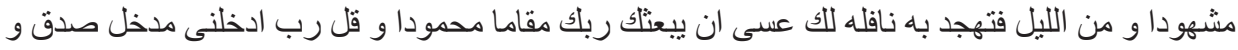

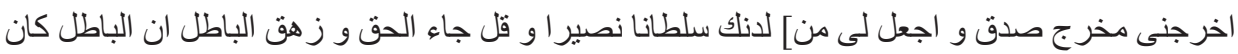

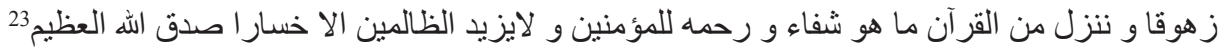

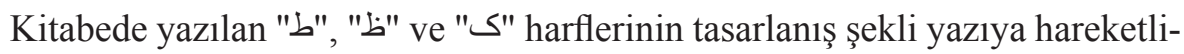
lik kazandırmıştır (Çizim 2)

İçbükey yüzeyli ikinci bordürde, bitkisel süslemeli zemin üzerine kabartma tekniğinde yazılan sülüs kitabe, Hac Suresinin 77-78. ayetlerini ihtiva etmektedir (Resim 4; Çizim 3):

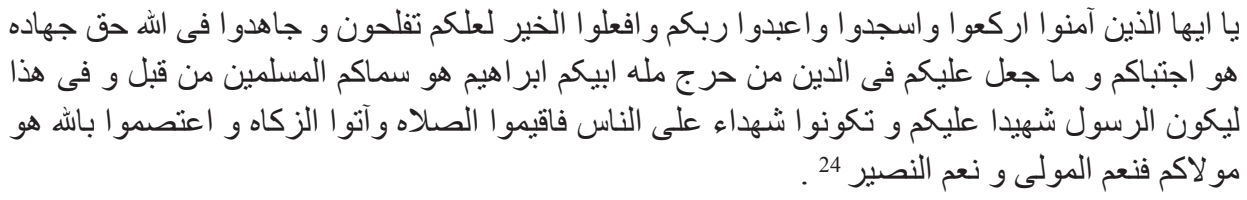

Sivri kemerli mihrap kavsarasında yazı bordürüyle birlikte iki kademeli alçı silme ile çerçevelenen simetrik girift süsleme bulunmaktadır. Söz konusu süsleme, tepelik, sade ve kanatlı rumiler ve içi oyuk kıvrıkdallardan oluşmaktadır. Kavsaranın en üst kısmında bir tepelik rumi bulunmaktadır. Rumilerin yüzeyle-

21 Bu makalede, Kur'an ayetlerini içeren tüm kitabelerin anlamları, Diyanet İşleri Başkanlığı'nın Resmi Kur'an-1 Kerim sayfasından alınmıştır. https://kuran.diyanet.gov.tr/, (24.12.2019).

22 Köşeli ayraç İçindeki kelimeler kitabeden zamanla dökülmüştür.

23 Anlamı: Rahman ve rahim olan Allah'ın adıyla. Güneşin zevalinden (öğle vaktinde Batı'ya kaymasından) gecenin karanlığına kadar (belli vakitlerde) namazı kıl. Bir de sabah namazını kıl. Çünkü sabah namazı şahitlidir. Gecenin bir kısmında da uyanarak sana mahsus fazla bir ibadet olmak üzere teheccüd namazı kıl ki, Rabbin seni Makam-1 Mahmud'a ulaştırsın. Deki: „Rabbim! (Gireceğim yere) doğruluk ve esenlik içinde girmemi sağla. (Çıkacağım yerden de) beni doğruluk ve esenlik içinde çıkar. Katından bana yardımcı bir kuvvet ver.“ De ki: „Hak geldi, batıl yok oldu. Şüphesiz batıl, yok olmaya mahkumdur.“ Biz Kur'an'dan, mü'minler için şifa ve rahmet olacak şeyler indiriyoruz. Zalimlerin ise Kur'an, ancak zararını artırır. Yüce Allah doğru söyledi.

24 Anlamı: Ey iman edenler, rükû edin, secde edin, Rabbinize kulluk edin ve hayır işleyin ki kurtuluşa eresiniz. Allah uğrunda hakkıyla cihad edin. O sizi seçti ve dinde üzerinize hiçbir güçlük yüklemedi. Babanız İbrahim'in dinine uyun. Allah sizi hem daha önce hem de bu Kur'an'da müslüman diye isimlendirdi ki, Peygamber size şahit (ve örnek) olsun, siz de insanlara şahit (ve örnek) olasınız. Artık namazı dosdoğru kılın, zekatı verin ve Allah'a sarılın. O sizin sahibinizdir. O ne güzel sahip, ne güzel yardımcıdır. 
rine ajde-kâri ${ }^{25}$ işlenmiştir (Resim 5; Çizim 4). Yazı bordürü, bitkisel süslemeli zemin üzerine kabartma olarak işlenmiş sülüs hatlı kitabe ile doldurulmuştur. Kitabenin içeriği İbrâhîm Suresinin 40-41. ayetleri ve "صدق اله العظيم" ibaresinden müteşekkildir (Resim 5; Çizim 6):

رب اجعلني مقيم الصلاه و من ذريتي ربنا و تقبل دعاء ربنا اغفر لي و لوالدي و للمؤمنين يوم يقوم

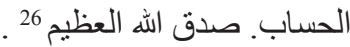

Kavsarayı çevreleyen sivri kemerin yüzeyinde, kabartma tekniğinde düğümlü ve yapraklı kûfi yazı karakterli bir kitabe yer almaktadır. Kitabe; Besmele, Mü'minûn Suresinin 1-5. ayetleri ile 6. ayetin ilk iki kelimesini içermektedir (Resim 5; Çizim 7):

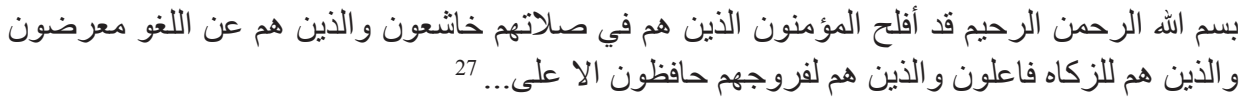

Kitabede Mü'minûn Suresinin 6. ayetinin sadece ilk iki kelimesinin yazılmas1, kitabenin tasarımının tek zayıf noktası olarak değerlendirebilir. Yazının dügü̈mlü alanlarında yaprak biçimli süslemelere yer verilmiştir. Sivri kemerin dış sınırlarını belirleyen şerit, üslûplaştırılmış lale ve yaprak motiflerinin dizilişinden meydana gelen tezyinatla bezenmiştir (Resim 5; Çizim 8). Köşelikleri sınırlayan şeritlerde aynı süsleme tekrar edilmiş̧tir (Resim 311). Köşeliklerde simetrik girift rumili süslemeler bulunmaktadır (Resim 6-7; Çizim 5). Mihrap nişi iki yandan sütuncelerle sınırlanmıştır. Sütuncelerin başlıklarının üzerine dikdörtgen şeklinde çıkıntılı ince bir tuğla yerleştirilmiştir (Resim 312). Sütuncelerin başlıklarında, bitkisel süslemeli zemin üzerinde kûfi hatlı yazılar bulunmaktadır. Sağ sütunce başlığında "الحُكم لله ibaresi, sol sütunce başlığında ise "القوة لله ibaresi yazılmıştır (Resim 312):

Sütunce gövdelerinin yüzeyine kazıma tekniğinde kesişen şeritlerin içerisine iki kenarı içbükey uzun altıgen ve içi boş eşkenar dörtgen dizisinden oluşmuş hendesi süsleme işlenmiştir (Resim 9; Çizim 9).

25 Ajde-kâri süzgeç biçimli yüzeylere sahip alçı işçiliğine denilmektedir. ajde-kâri'de genellikle hendesi motifler bulunmaktadır (Bkz.: Ali Ekber Deh-Hudâ, Lugatnâme, cilt I, Tahran, Müessese-i İntişarat ve Çap-i Danişgâh-i Tahran, 1377 H.Ş, s. 74).

26 Anlamı: "Rabbim! Beni namaza devam eden bir kimse eyle. Soyumdan da böyle kimseler yarat. Rabbimiz! Duamı kabul eyle.“ „Rabbimiz! Hesap görülecek günde, beni, ana-babamı ve inananları bağışla." Yüce Allah doğru söyledi.

27 Anlamı: Rahman ve rahim olan Allah'ın adıyla. Mü‘minler gerçekten kurtuluşa ermişlerdir. Onlar ki, namazlarında derin saygı içindedirler. Onlar ki, faydasız işlerden ve boş sözlerden yüz çevirirler. Onlar ki, zekatı öderler. Onlar ki, ırzlarını korurlar. hariç... 
Sivri kemerle sınırlanmış içbükey yüzeyli niş kısmında iki yandan hendesi bezemeli yüzeylere sahip iki küçük sütunce görülmektedir (Resim 10, 12). Sütuncelerin başlığ1 yoktur. Tahribe uğramış sütuncelerin süslemeleri küçük ve büyük üç boyutlu küplerden ibarettir. Küpler arasında kalan boşluklara beş köşeli ters-düz yıldızlar işlenmiştir. Söz konusu süslemeler kazıma tekniğinde yapılmıştır (Resim 11).

Sivri kemerle sınırlanan nişte yazı bordürü ile bir alçı silmenin çevrelediği simetrik girift süsleme kompozisyonu bulunmaktadır. Söz konusu tezyînât, mihrap kavsarasında olduğu gibi, sade, kanatlı ve tepelik rumiler ile içi oyuk kıvrıkdalların kaynaşmasından meydana gelir. Rumilerin yüzeylerine ajde-kâri bezeme uygulanmıştır (Resim 10, 12; Çizim 10). Bordürdeki kûfi kitabe, rumi süslemeli zemin üzerinde kabartma olarak işlenmiştir. Kitabenin içeriği Besmele ve Hûd Suresinin 114. ayetidir (Resim 10, 12; Çizim 11):

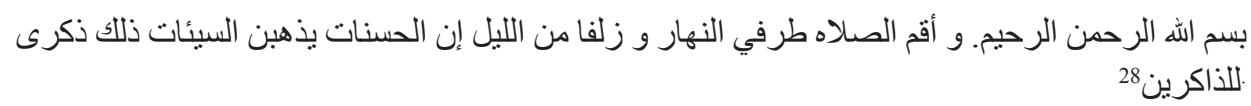

sivri kemerin kıvrıkdal ve rumi süslemeli yüzeyine kabartma tekniğinde işlenmiş sülüs hatlı kitabe, Besmele, Âl-i İmrân Suresinin 18. ayeti ile 19. ayetinin ilk kelimelerini içermektedir (Resim 10, 12; Çizim 12):

شهـد الله أنه لا إله إلا هو والملائكه و أولو العلم قائما بالقسط لا إله إلا هو العزيز الحكيم إن الدين عند الله

Kitabenin üst kısımlarında, kıvrıkdallara tutturulmuş sade ve kanatlı rumilere yer veriliştir (Çizim 13). Köşelikleri sınırlayan şerit, dizili yaprak biçimli süslemeler içermektedir. Kemerin köşeliklerinde simetrik girift rumi kompozisyon yer almaktadır (Resim 13; Çizim 14). Mihrabın en alt kısmında ters "U" biçimli bordürdeki kıvrıkdal ve rumi süslemeli zemin üzerine kabartma olarak işlenmiş kûfi kitabe, Besmele ve İsrâ Suresinin 110. ayetini ihtiva etmektedir ${ }^{30}$ (Resim 14): بسم الله الرحمن الرحيم. قل ادعوا الله أو ادعوا الرحمن أيا ما تدعو ا فله الأسماء الحسنى و لا تجهر بصلاتك

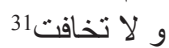

28 Anlamı: Rahman ve rahim olan Allah`ın adıyla. Gündüzün iki tarafında ve gecenin gündüze yakın vakitlerinde namaz kıl. Çünkü iyilikler kötülükleri giderir. Bu, öğüt alanlar için bir ögüttür.

29 Anlamı: Rahman ve rahim olan Allah'ın adıyla. Allah, melekler ve ilim sahipleri, ondan başka ilah olmadığına adaletle şâhitlik ettiler. Ondan başka ilah yoktur. O, mutlak güç sahibidir, hüküm ve hikmet sahibidir. Şüphesiz Allah katında din İslam‘dır.

30 Ayetin son beş kelimesi kitabede yazılmamıştır.

31 Anlamı: Rahman ve rahim olan Allah`ın adıyla. De ki: „(Rabbinizi) ister Alladiye çağırın, ister Rahman diye çağırın. Hangisiyle çağırırsanız çağırın, nihayet en güzel isimler O‘nundur.“ Namazında sesini pek yükseltme, çok da kısma. 
Ters "U” biçimli bir çerçeveye alınan dikdörtgen panodaki alçı süslemeler tamamen tahrip olmuştur. Bu nedenle içeriği ile ilgili herhangi bir bilgi elde etmek mümkün değildir.

Caminin asıl mihrabının dışında, doğu taraftaki yan mekânda ikinci mihrap yer almaktadır. Sivri kemerli, 3.70×1.60 ölçülerindeki mihrabın içbükey hafif kavisli sivri kemerinin dış sınırlarını belirleyen şeritte, kazıma tekniğinde işlenmiş yaprak dizilerinden müteşekkil süslemeler bulunmaktadır (Resim 15-16). Köşelikleri sınırlayan şeritler de aynı süslemeyi içermektedir. Köşeliklerde kabartma olarak uygulanmış simetrik rumilerden oluşmuş girift kompozisyona yer verilmiştir. Rumilerin yüzeylerinde ajde-kâri görülmektedir (Resim 16). Sivri kemerin kıvrıkdal ve rumi süslemeli zemini üzerine kabartma olarak işlenmiş sülüs hatlı kitabe, Besmele ve Mü’minûn Suresinin 1-5. ayetlerini içermektedir:

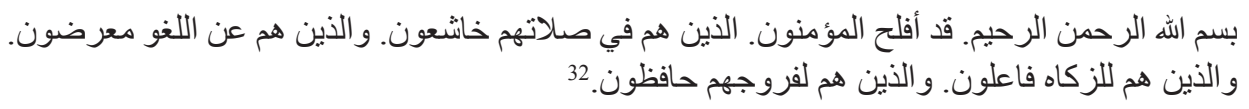

Sivri kemerin içerisinde simetrik iri rumilerden oluşmuş girift süsleme bulunmaktadır. Söz konusu süslemeler kabartma tekniğinde işlenmiştir. Rumilerin yüzeylerinde ajde-kâri görülmektedir (Resim 16).

Mihrap nişi iki yandan tuğla sütuncelerle sınırlanmıştır. Başlıksız yarım altıgen prizma şeklinde olan sütuncelerin üst kısımlarında dikdörtgen formunda ince, çıkıntılı birer tuğla yerleştirilmiştir. En altta ters "U" biçimli bordürde kıvrıkdal ve rumi süslemeli zemin üzerine kabartma olarak işlenmiş sülüs hatlı kitabenin içeriği Besmele ve İhlas Suresidir (Resim 17):

$$
\text { بسم الله الرحمن الرحيم. قل هو الله احد. الله الصمد. لم يلد ولم يولا. ولم يكن له كفو ا احد33 }
$$

Ters "U" biçimli bir bordür ile kuşatılan dikdörtgen alçı pano oldukça harap halde bulunduğundan içeriği hakkında bilgi edinilememiştir.

Caminin üçüncü mihrabı ikinci mihrabın doğusunda yer almakta ve onunla benzer özellikler taşımaktadır. $3.70 \times 1.60 \mathrm{~m}$ ölçülerinde olan mihrap sivri kemerlidir (Resim 18). Sivri kemerin dış sınırlarını belirleyen şeritte, kazıma tekniğinde işlenmiş dizili yaprak biçimli süslemelere yer verilmiştir. Köşelikleri

32 Anlamı: Rahman ve rahim olan Allah'ın adıyla. Mü‘minler gerçekten kurtuluşa ermişlerdir. Onlar ki, namazlarında derin saygı içindedirler. Onlar ki, faydasız işlerden ve boş sözlerden yüz çevirirler. Onlar ki, zekatı öderler. Onlar ki, ırzlarını korurlar.

33 Anlamı: Rahman ve rahim olan Allah“ın adıyla. De ki: „O, Allah“tır, bir tektir.“ „Allah Samed'dir. (Her şey O'na muhtaçtır, o, hiçbir şeye muhtaç değildir.)“ Ondan çocuk olmamıştır (Kimsenin babası değildir). Kendisi de doğmamıştır (kimsenin çocuğu değildir).“ „Hiçbir şey O'na denk ve benzer değildir.“ 
sınırlayan şeritler de aynı süslemeyi içermektedir. Köşeliklerde kabartma tekniğinde işlenmiş simetrik rumilerden oluşmuş girift bir süsleme bulunmaktadır (Resim 19). Rumilerin yüzeylerine ajde-kâri işlemiştir. Sivri kemerin yüzeyi oldukça tahribe uğramıştır. Burada kıvrıkdal ve rumi süslemeli zemin üzerine kabartma olarak yazılmış sülüs kitabe, Besmele ve Hicr Suresinin 97-99. ayetlerini içermektedir:

بسم الله الرحمن الرحيم. و لقد نعلم ان يضيق صدرك بما يقولون فسبح بحمد ربك وكن من الساجدين و اعبد ربك حتى ياتيك اليقين.34 - 2

Mihrabın sivri kemeri, kıvrıkdal ve rumi motifli bir şerit ile çevrelenmiştir. Sivri kemerin içerisinde ise, simetrik iri rumilerden oluşmuş girift süsleme kompozisyonu yer almaktadır. Söz konusu süslemeler kabartma tekniğinde işlenmiştir. Rumilerin yüzeylerinde ajde-kâri görülmektedir (Resim 19). Mihrap nişi iki yandan tuğla sütuncelerle sınırlanmıştır. Başlıksız yarım altıgen prizma şeklinde olan sütuncelerin üst kısımlarına dikdörtgen biçimli ince çıkıntılı birer tuğla yerleştirilmiştir. Mihrabın en alt kısmında ters "U" biçimli bordürde kıvrıkdal ve rumi süslemeli zemin üzerine kabartma tekniğinde işlenmiş sülüs kitabe, Kehf Suresinin 110. ayetini ihtiva etmektedir (Resim 20):

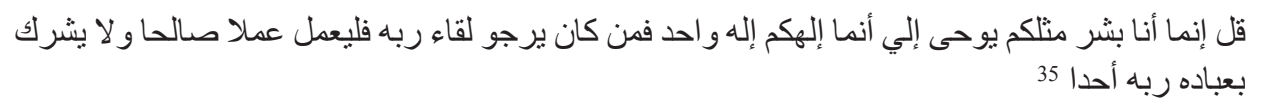

Ters "U" biçimli bir bordür ile kuşatılan dikdörtgen panoya kûfi kitabe ve süslemeler işlenmiştir. Tezyinî ve müşeccer kûfi kitabe, tepelik, sade rumi ve içi oyuk kıvrıkdallardan oluşmuş girift bitkisel kompozisyon ile bezeli zemin üzerine yazılmıştır. Kabartma olarak işlenmiş kitabenin içeriği "وكن في صلاتكا خاثعا" ibaresidir (Resim 20).

Kubbeli mekândaki dört sivri kemerin karınlarında işlenmiş kitabe ve süslemeler birbirine benzer özelliklere sahiptir. Kitabelerde dikkate değer husus, "ط", "ظ” ve "ك" harflerinin eğri olarak tasarlanmasıdır. Ayrıca bazı harflerin üstünde tirfil işareti bulunmaktadır. Kitabelerin yazı türü yapraklı kûfidir. Rumi süslemeli zemin üzerinde yazılan kitabenin rengi beyaz, rumilerin rengi ise kahverengidir.

34 Anlamı: Rahman ve rahim olan Allah'1n adıyla. Andolsun, onların söyledikleri şeylerden dolay1 göğsünün daraldığını biliyoruz. O halde Rabbini hamd ile tesbih et (yücelt) ve secde edenlerden ol. Sana ölüm gelinceye kadar Rabbine ibadet et.

35 Anlamı: De ki: „Ben de ancak sizin gibi bir insanım, (Ne var ki) bana, 'Sizin ilah'ınız ancak bir tek ilâhtır" diye vahyolunuyor. Kim Rabbine kavuşmayı umuyorsa yararlı bir iş yapsın ve Rabbine ibadette kimseyi ortak koşmasın." 
Caminin ana mihrabının solunda, kubbeli mekânın doğusundaki yan mekâna girişin sağlandığ silme arasında kalan alana yazılmıştır. Merkezde ise kahverengi düz dikdörtgen silme ile çevrelenen Yunan anahtar motifi yer almaktadır. Söz konusu süsleme kazıma tekniğinde yapılmıştır. Kitabe, rumi süslemeli zemin üzerine, yapraklı kûfi hatla kabartma olarak işlenmiş Besmele ile Cuma Suresinin 9. ayetini ihtiva etmektedir (Resim 21):

البيع ذلكم خير لكم إن كنتم تعلمون. الرحما الذين آمنوا إذا نودي للصعلاه من يوم الجمعه فاسعوا إلى ذكر الله و ذروا

Kubbeli mekânına girişi sağlayan kemerin solunda, doğu taraftaki yan mekâna girişin sağlandığı kemerin karnında bulunan kitabe, iç içe iki düz dikdörtgen silme arasında kalan alana yazılmıştır. Merkezde kahverengi düz dikdörtgen silme ile çevrelenen Yunan anahtar motifi bulunmaktadır. Söz konusu süsleme kazıma tekniğinde yapılmıştır. Rumi süslemeli zemin üzerine, yapraklı kûfi hatla kabartma olarak işlenmiş kitabe Besmele ve Ahzâb Suresinin 41-43. ayetlerini içermektedir (Çizim 15-16):

يا أيها الذين آمنوا اذكر[و]| الله ذكرا كثير ا و سبحوه بكره و أصيلا. هو الذي يصلي عليكم و ملائكته ليخرجكم من الظلمات إلى النور وكان بالمؤمنين رحيما. 37

Kubbeli mekâna girişi sağlayan kemerin sağında, batı tarafta yan mekâna girişin sağlandığı kemerin karnında bulunan kitabe ise, iç içe iki düz dikdörtgen silme arasında kalan alana yazılmıştır. Merkezde kahverengi düz dikdörtgen silme ile kuşatılan Yunan anahtar motifi görülmektedir. Söz konusu süsleme kazıma tekniğinde yapılmıştır. Kitabe, rumi süslemeli zemin üzerinde, yapraklı kûfi hatla kabartma olarak yazılmış olup Besmele ve Tevbe Suresinin 128-129. ayetlerini ihtiva eder (Resim 22; Çizim 17):

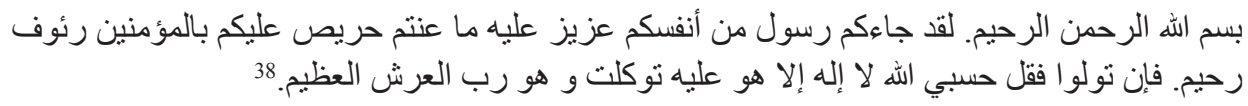

36 Anlamı: Rahman ve rahim olan Allah'ın adıyla. Ey iman edenler! Cuma günü namaz için çağrı yapıldığı zaman, hemen Allah'ın zikrine koşun ve alışverişi bırakın. Eğer bilirseniz bu, sizin için daha hayırlıdır.

37 Anlamı: Ey iman edenler! Allah'1 çokça zikredin. Onu sabah akşam tespih edin. O, sizi karanlıklardan aydınlığa çıkarmak için size merhamet eden; melekleri de sizin için bağışlanma dileyendir. Allah mü'minlere çok merhamet edendir.

38 Anlamı: Rahman ve rahim olan Allah'ın adıyla. Andolsun, size kendi içinizden öyle bir peygamber gelmiştir ki, sizin sıkıntıya düşmeniz ona çok ağır gelir. O size çok düşkün, mü ‘minlere karşı da çok şefkatli ve merhametlidir. Eğer yüz çevirirlerse de ki: „Bana Allah yeter. O‘ndan başka hiçbir ilah yoktur. Ben ancak O`na tevekkül ettim. O, yüce Arşın sahibidir.“ 
Ana mihrabın sağında, batı duvarındaki sonradan tuğla ile örülerek kapatılan kemerin karnında yer alan kitabe, iç içe iki düz dikdörtgen silme arasında kalan alana yazılmıştır. Merkezde kahverengi düz dikdörtgen silme ile çevrelenen Yunan anahtar motifi işlenmiştir. Söz konusu süsleme kazıma tekniğinde yapılmıştır. Kitabe, rumi süslemeli zemin üzerinde, yapraklı kûfi hatla kabartma olarak yazılmış olup Besmele ve Enfâl Suresinin 2-4. ayetlerini içermektedir (Resim 23; Çizim 18):

بسم الله الرحمن الرحيم. إنما المؤمنون الذين إذا ذكر الله و جلت قلوبهم و إذا تليت عليهم آياته زادتهم إيمانا

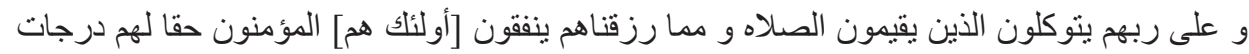

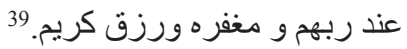

Güney eyvanının doğu, batı ve güney duvarlarının üst kısımlarında ve sivri tonoz örtünün eteğinde alçı süsleme ve kitabe bulunmaktadır (Resim 24-27). Burada sade ve tepelik rumilerle elde edilen süsleme, yapıda kendine özgü bir kompozisyon ortaya çıkarmıştır. Kabartma tekniğinde işlenmiş bu süslemeler çıplak tuğla üzerine tatbik edilmelerinden ötürü büyük ölçüde dökülmüş vaziyettedir (Resim 27). Sarmaşık biçimli bitkileri hatırlatan rumi süslemelerin yüzeylerine sathi kazıma tekniğiyle ince dallı çiçekler işlenmiştir. Kubbeli mekâna girişi sağlayan sivri kemerin köşeliklerinde ve iki yanında yer alan dikey dikdörtgen panolardaki süslemeler benzer özellikler göstermektedir (Resim 24). Kabartma tekniğinde yap1lan bu süslemeler, simetrik rumilerden oluşmuş kompozisyona sahiptir.

Güney eyvanın duvarlarının üst kısmını kaplayan bu süslemelerin dışında, tonoz başlangıç seviyesinden itibaren başlayan kitabe, dikkati çekmektedir. Söz konusu kitabe, tepelik, sade rumi ve içi oyuk kıvrıkdallardan oluşmuş girift bitkisel süslemelerle bezeli zemin üzerine yazılmıştır (Resim 24-26; Çizim 19). Kabartma tekniğinde sülüs hatla işlenmiş kitabe, Besmele, Bakara Suresinin 255. ayeti (Ayet-el Kürsi) ile mimarın ismi ve inşa tarihini ihtiva etmektedir:

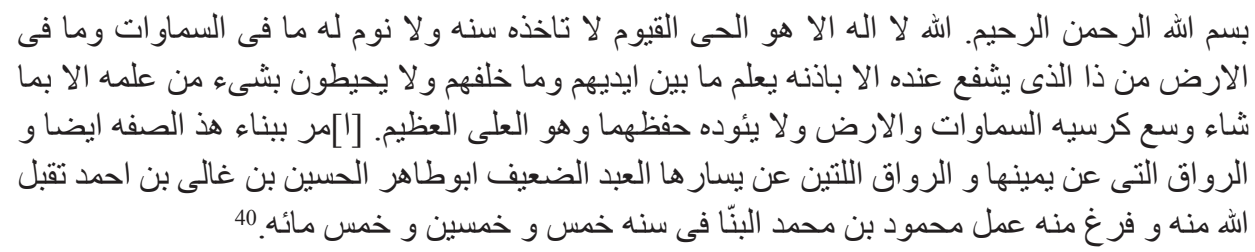

39 Anlamı: Rahman ve rahim olan Allah`ın adıyla. Mü‘minler ancak o kimselerdir ki; Allah anıldığı zaman kalpleri ürperir. Onun âyetleri kendilerine okunduğu zaman (bu) onların imanlarını artırır. Onlar sadece Rablerine tevekkül ederler. Onlar namazı dosdoğru kılan, kendilerine rızık olarak verdiğimiz şeylerden Allah yolunda harcayan kimselerdir. ]İşte onlar[ gerçekten mü‘minlerdir. Onlara, Rableri katında yüksek mertebeler, bağışlanma ve cömertçe verilmiş rizık vardir.

40 Anlamı: Rahman ve rahim olan Allah'ın adıyla. Allah kendisinden başka hiçbir ilah olmayan- 
Eşkenar dörtgen ve daire dizisinden oluşmuş hendesi bezemeli bir bordür ile çerçevelenen kitabe, güney duvarında, kubbeli mekâna girişi sağlayan sivri kemerin üstünde yer almaktadır.

Bezemeli bordürde, eşkenar dörtgen ve daire şekillerinin arasında oluşmuş üçgenlerin içine üçer küçük üçgen kazınmıştır. Kubbeli mekâna girişi sağlayan sivri kemerin sol tarafındaki dikey dikdörtgen panonun altında, kabartma tekniğinde işlenmiş bir kitabe bulunmaktadır. ${ }^{41}$ Rumi süslemeli zemin üzerindeki düğümlü kûfi kitabenin içeriği tahrip olduğu için anlaşılamamaktadir (Resim 28).

Kubbeli mekâna girişi sağlayan sivri kemerin yüzeyinde kabartma tekniğinde işlenmiş bir kitabe bulunmaktadır. Bazı kısımları dökülerek günümüze gelen kitabenin yazı türü meşrik (doğu) kûfisidir. Rumi süslemeli zemin üzerinde yer alan kitabe, Fussilet Suresinin 37-38. ayetlerini ihtiva etmektedir (Resim 29; Çizim 22):

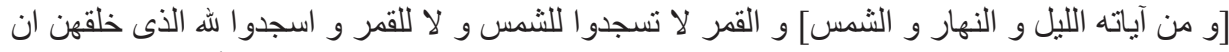

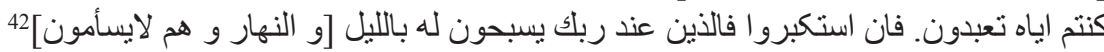

Kubbeli mekâna girişi sağlayan sivri kemerin karnındaki kitabe, iç içe iki düz dikdörtgen silme arasında kalan alana yazılmıştır (Resim 30; Çizim 20). Merkezde beyaz renkli düz dikdörtgen silme ile çevrelenen sekiz kollu yıldızlar işlenmiştir. Yıldızların karnında altıgen, kollarında ise üçer küçük üçgen görülür. Sekiz kollu yıldızların birleşmesinden sekizgen ve uçları sivri haçvari motifleri meydana gelmiştir. Söz konusu süslemeler kazıma tekniğinde yapılmıştır (Çizim 21). Sülüs karakterli kitabe ise rumi süslemeli zemin üzerine ka-

dır. Diridir, kayyumdur. Onu ne bir uyuklama tutabilir, ne de bir uyku. Göklerdeki her şey, yerdeki her şey onundur. İzni olmaksızın onun katında şefaatte bulunacak kimdir? O, kulların önlerindekileri ve arkalarındakileri (yaptıklarını ve yapacaklarını) bilir. Onlar onun ilminden, kendisinin dilediği kadarından başka bir şey kavrayamazlar. Onun kürsüsü bütün gökleri ve yeri kaplayıp kuşatmıştır (O, göklere, yere, bütün evrene hükmetmektedir.). Gökleri ve yeri koruyup gözetmek ona güç gelmez. O, yücedir, büyüktür. Ebû Tâhir el-Huseyn b. Ğâlî b. Ahmed bu sofayı ve sofaya sağdan bitişen bir, soldan bitişen iki adet revakın yapımını emretti. Allâh onun hayrını kabul etsin. Yapının inşası 555 yılında tamamlandı. İnşayı, Mahmûd b. Muhammed el- Benna yapti.

41 Kemerin sağ tarafında da benzer kompozisyona sahip başka bir kitabenin olabileceği kanaatindeyiz.

42 Anlamı: [Gece, gündüz, güneş] ve ay Allah'ın varlığının delillerindendir. Güneşe ve aya secde etmeyin. Eğer gerçekten Allah'a kulluk ediyorsanız, onları yaratan Allah'a secde edin. Eğer onlar büyüklük taslarlarsa, bilsinler ki Rabbinin yanında bulunanlar (melekler), gece [gündüz hiç usanmadan] onu tespih ederler. 
bartma olarak yazılmıştır. Kitabenin içeriği Besmele ve Furkân Suresi 61-65. ayetleridir:

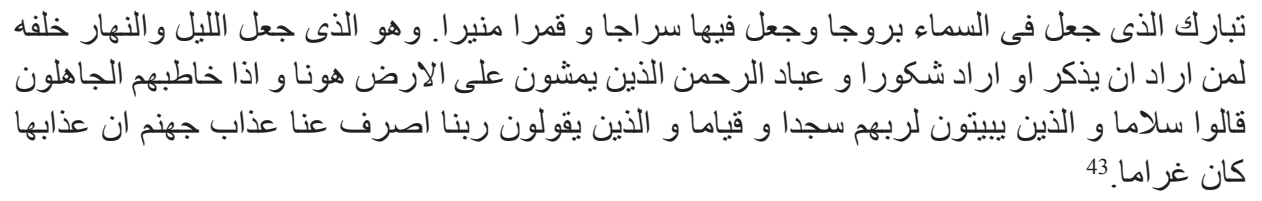

Kubbeli mekâna giriş açıklı̆g 1 altta basık üstte sivri kemerlidir. Kemere ait ayakların iç yüzeylerinde iki silme arasındaki geçme motifli bordür ile kuşatılan sarmaşık üzerine yapılmış ters ve düz yaprak motifleri bulunmaktadır. Söz konusu süsleme kazıma tekniğinde yapılmıştır (Resim 31-32; Çizim 23).

Güney eyvan tonozunun başlangıç noktasındaki kemerin karnında bir kitabe görülür. Kitabede düğüm şeklinde süslemeler ve tirfil işareti bulunmaktadır. İçi oyuk kıvrıkdallar, ortabağ ile sade ve tepelik rumilerden oluşmuş bitkisel kompozisyon ile süslenmiş zemin üzerine kabartma olarak yazılmış kitabe, Besmele, İslam hukuku âlimi ve Şafii mezhebinin kurucusu olan İmam Şafii hakkında söylenmiş üç beyitlik şiir ${ }^{44}$ ve kısa bir dua ihtiva etmektedir (Resim 33-36; Çizim 24):

43 Anlamı: Rahman ve rahim olan Allah'ın adıyla. Göğe burçlar yerleştiren, orada bir 1şık kaynağı (güneş) ve aydınlatıcı bir ay yaratanın şanı çok yücedir. O, öğüt almak isteyen ve çok şükredici olmayı dileyen kimseler için geceyi ve gündüzü birbiri ardınca getirendir. Rahmân'ın kulları, yeryüzünde vakar ve tevazu ile yürüyen kimselerdir. Cahiller onlara laf attıkları zaman, "selâm!“ der (geçer)ler. Onlar, Rabblerine secde ederek ve kıyamda durarak geceleyenlerdir. Onlar, şöyle diyenlerdir: „Ey Rabbimiz! Bizden cehennem azabını uzaklaştır, gerçekten onun azabı sürekli bir helaktir!"

44 İbnü'l-Hatib, A'malü'l-A'lam adlı eserinde bu şiirin Ebû Abdillah b. Merzûk'a ait olduğunu kaydeder. (Bkz.: Ebu Abdullah Lisanüddin Muhammed b. Abdullah İbnü'l-Hatib, A'malü 'l-A 'lam, cilt I, Beyrut, Darü‘l-Kütübi‘l-İlmiyye, 2003, s. 141.) Farklı kaynaklarda şiirin ikinci mısrasının farklı şekillerde yazıldığı görülmektedir (Bkz.: Ebu Zekeriyya Muhyiddin Yahya b. Şeref En-Nevevi, Tehzibu 'l-Esmai vel-Lügat, Dımaşk, Darü'1-Feyha, 2013, s. 46.; Halid İbn İsa Balavi, Tacül-Mefrik fi Tahliyat-ül-ulamâ-il-Meşrik, Riyad, Metba'at Muhammed el-Hamis el-Sakafiye vel-Camiye, 2013, s. 38.; Muhammed ibn Muhammed, Kitab-ülErba 'in fi İş̧ad-ül-Sa'irin İla Menazil-ül-Muttekin, Beyrut, Darü‘1-Kütübi'l-İlmiyye, 1998, s. 139.; Seyyid Üveys, Resail ela al-İmam el-Şafi: Zahiret İrsal el-Resail ela Derii el-İmam el-Şafii, Kahire, Dar-ül Şayi, 1978, s. 18.). Nevevi, "Tehzibu'l-Esmai vel-Lügat" adlı eserinde, 574/1179 y1lında Selâhaddîn Eyyûbînin İmam Şâfî̂’nin mezarı için bir ahşap sanduka yaptırıp üzerine bahsi geçen şiirin yazılmasını istediğini ve sandukanın da Ubayd Ebü‘lMeâlî adlı sanatçı tarafından yapıldığını kaydetmektedir (Bkz.: En-Nevevi, Tehzibu 'l-Esmai vel-Lügat, s. 46.; Maurice Sven Dimand, Fünûn-ul İslami, Gize, Vekalet1l- Sahafeti'1-Arabiyye, 2018, s. 30.). 
[بسم الله الرحمن الرحيم الثافعي إمام الناس كلهم في] الحلم و العلم و العلياء و الجود و البالس لـه الإمامه في الدنيا مسلمه كما الخلا]فه في أو لاد عباس أصحابه خير [أصحاب الصاب و مذهبه خير] المذاهب

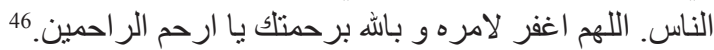

Mihrap önü kubbeli mekânda beden duvarlarının üstünü dolaşan, eserin inşası ile ilgili çok önemli bilgiler içeren bir yazı kuşağı bulunmaktadır. Kûfi hatlı kitabe içerisine düğüm şeklinde süslemeler ve tirfil işareti yerleştirilmiştir. Kubbeli mekânın kuzey doğu köşesinden başlayan kuşak, mekânın tüm duvarlarını dolaşıp, aynı köşede son bulur. Kıvrıkdallar, ortabağ ve sade ve tepelik rumilerden oluşmuş girift bitkisel süslemelerle bezeli zemin üzerindeki kitabe sülüs hatlı olup Besmele, Tevbe Suresinin 18. ayeti ve caminin inşa kitabesini (caminin bölümleri, banisi, mimarı ve inşa tarihi) içermektedir (Resim 37-39; Çizim 25-26):

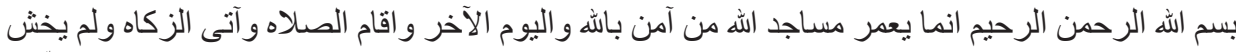

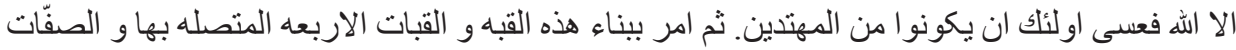

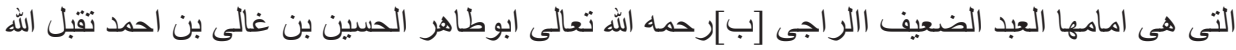

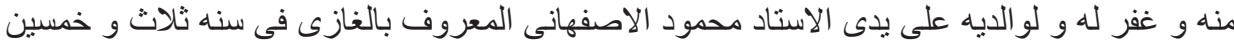

و خمس مائه.

Kitabe eşkenar dörtgen dizisinden oluşmuş hendesi bezemeli bir bordür ile çevrelenmiştir. Bordürde, eşkenar dörtgenlerin arasında oluşmuş üçgenlerin içerisine üçer küçük üçgen kazınmıştır (Resim 40; Çizim 27).

Kubbenin alt kısımlarında bulunan üç dilimli tromplardaki sathi sivri kemerli nişlerde kazıma tekniğinde işlenmiş altı kollu yıldız, küçük ve büyük üç boyutlu

45 Dört eyvanlı camilerden önce dört eyvanlı medreselerin var olduğunu ve bazı medreselerin her eyvan ve ona ait mekânları bir mezhebe (Hanefî, Şâfî̀, Mâlikî ve Hanbelî) ait olduğu bilinmektedir (Bkz.: Katharina Otto-Dorn, Islamic Art, California, University of California Press, 1976, s. 103.). Bu bilgiden hareketle caminin güney eyvanın Şâfî̀ mezhebine öteki eyvanların ise diğer üç mezhebe ait olduğu söylenebilir.

46 Anlamı: Rahman ve rahim olan Allah'ın adıyla. (İmam) Şafii, sabır, ilim, üstünlük, cömertlik ve mertlikte tüm insanların lideridir. Dünyada onun liderliği, Abbas oğullarının hilafet makamına sahip oluğu gibi kesindir. Allah katında ve halk nezdinde ona tabi olanlar en iyiler ve onun mezhebi mezheplerin en iyisidir. Allah'ım! Onun yaptıklarını rahmetinle bağışla ey merhametlilerin en merhametlisi.

47 Anlamı: Rahman ve rahim olan Allah'ın adıyla. Allah'1n mescitlerini, ancak Allah'a ve ahiret gününe inanan, namazı dosdoğru kılan, zekâtı veren ve Allah'tan başkasından korkmayan kimseler imar eder. İşte onların doğru yolu bulanlardan olmaları umulur. Bu kubbenin ve ona bitişik olan dört kubbenin ve önündeki sofaların (Eyvanların) inşasını Allâh'ın rahmetini dileyen zayıf kul Ebû Tâhir Hüseyn b. Ğâlî b. Ahmed emretmiştir. Allâh onun ve ebeveyninin günahlarını bağışlasın. Gâzi diye ün yapmış üstad Mahmud İsfahânî tarafından 553 yılında yapılmıştır. 
küpler ve kelebek şeklini andıran motiflerden oluşmuş hendesi süslemeler bulunmaktadır (Resim 41-43; Çizim 28). Söz konusu motiflerin arasında kalan boş sahalara küçük üçgen ve yıldızlar kazınmıştır. Kasnak seviyesinde bulunan ara yüzlerde, üç dilimli kemerin içine aynı şekilde üç yüzeysel sivri kemerli niş yerleştirilmiştir. Bu nişlerde ise simetrik sade ve tepelik rumilerden oluşmuş bitkisel süsleme kompozisyonu bulunmaktadır. Süslemelerin yüzeylerine sathi kazıma tekniğiyle ince dallı çiçek motifleri işlenmiştir. Kasnaktaki üç dilimli kemerleri kuşatan sivri kemerlerin karnında iki sıra tuğla arasında eşkenar dörtgen ve daire dizisinden oluşmuş hendesi bezemeli bir bordür bulunmaktadır. Bordürde, eşkenar dörtgen ve daire şekillerinin arasında oluşmuş üçgenlerin içerisine üçer küçük üçgen kazınmıştır.

Kubbeli mekânda beden duvarları üzerinde mihrap ile aynı hizada toplam altı sathi sivri kemerli niş bulunmaktadır (Resim 44-49; Çizim 29). Doğu ve batı duvarları üzerindeki nişler ise basık kemerli bir girinti içerisinde yer almaktadır. Mihrabın sol ve sağ tarafinda ve kubbeli mekâna girişi sağlayan kemerin sol ve sağ taraflarındaki nişlerde kitabe ve süsleme, doğu ve batı duvarları üzerindeki nişlerde ise yalnızca süsleme yer almaktadır.

Mihrabın doğu tarafında yer alan birinci nişin üst kısmında kabartma tekniğinde işlenmiş simetrik rumi, kıvrıkdal, ortabağ ve sade ve tepelik rumilerden oluşmuş süsleme kompozisyonu bulunmaktadır. Rumilerin yüzeylerine sathi kazıma tekniğiyle küçük daire ve ince dallı çiçek motifleri işlenmiştir. Nişin alt kısmında ise dikdörtgen bir silme ile çerçevelenen kitabe, kabartma olarak yazılmıştır. Simetrik girift rumiler ile bezeli zemin üzerindeki kitabe düğümlü kûfi hatl1 olup, ("و كن في صلاتك خاشعا"Anlamı: ve namazında mütevazi ol) ibaresini içermektedir (Resim 44) Bu kitabe muhteva açısından yapının üçüncü mihrabının niş kısmındaki ters "U" biçimli çerçeve ile kuşatılan dikdörtgen panoda işlenmiş kitabe ile benzerlik göstermektedir.

Kubbeli mekânda doğu taraftaki duvar üzerinde yer alan ikinci nişte sadece süsleme görülmektedir. Kabartma tekniğinde işlenmiş süsleme simetrik kıvrıkdal, ortabağ ve sade ve tepelik rumilerden müteşekkildir. Rumilerin yüzeylerine sathi kazıma tekniğiyle küçük daire ve ince dallı çiçek motifleri işlenmiştir (Resim 45). Kubbeli mekâna girişi sağlayan kemerin sol (doğu) tarafindaki üçüncü nişte kitabe ve süsleme bulunmaktadır. Nişin üst kısmında kabartma tekniğinde simetrik olarak işlenmiş kıvrıkdal ve sade ve tepelik rumilerden oluşmuş süslemeler yer almaktadır. Rumilerin yüzeylerine sathi kazıma tekniğiyle küçük daire ve ince dallı çiçek motifleri tatbik edilmiştir. Nişin alt kısmında ise dikdörtgen bir silme ile çerçevelenen kitabe, kabartma halde yazılmıştır. Simetrik girift rumiler 
ile bezeli zemin üzerindeki düğümlü kûfi hatlı kitabe,"و 48 (Anlamı: Sana ölüm gelinceye kadar Rabbine ibadet et.) ibaresini ihtiva eder (Resim 46). Kubbeli mekâna girişi sağlayan kemerin sağ (batı) tarafındaki dördüncü nişte de kitabe ve süslemeler bulunmaktadır. Nişin üst kısmında kabartma tekniğinde tatbik edilmiş simetrik kıvrıkdal ve sade ve tepelik rumilerden oluşmuş süslemelere yer verilmiştir. Rumilerin yüzeylerine sathi kazıma tekniğiyle küçük daire ve ince dallı çiçek motifleri işlenmiştir. Nişin alt kısmında ise dikdörtgen bir silme ile çerçevelenen kitabe, kabartma olarak yazılmıştır. Simetrik girift rumi süslemeler ile bezeli zemin üzerindeki düğümlü kûfi hatl1 kitabe, قد افلح من تزكى (Anlamı: Arınan ve Rabbinin adını anıp, namaz kılan kimse mutlaka kurtuluşa erer.) ibaresini ihtiva eder (Resim 47).

Kubbeli mekânda batı taraftaki duvar üzerinde yer alan beşinci nişte yalnızca kabartma tekniği ile yapılmış bezemeler mevcuttur. Simetrik kıvrıkdal ile sade ve tepelik rumilerden oluşmuş düzenlemede rumilerin yüzeylerine sathi kazıma tekniğiyle küçük daire ve ince dallı çiçek motifleri işlenmiştir (Resim 48; Çizim 29).

Mihrabın batı tarafinda yer alan altıncı nişin üst kısmında kabartma tekniğinde işlenmiş simetrik kıvrıkdal ve sade ve tepelik rumilerden oluşmuş süsleme kompozisyonu görülmektedir. Rumilerin yüzeylerine sathi kazıma tekniğiyle küçük daire ve ince dallı çiçek motifleri işlenmiştir. Nişin alt kısmında ise dikdörtgen bir silme ile çevrelenen zemine kabartma olarak bir kitabe işlenmiştir. Simetrik girift rumi süslemeli zemin üzerine yazılan dügüumlü kûfi hatlı kitabe zeminin tahrip olması nedeniyle okunamamaktadır (Resim 49).

Kubbeli mekân ve güney eyvanın tuğlaları arasındaki derzlere kalıplama tekniğinde yapılmış hendesi alçı süslemeler yerleştirilmiştir. Bu süslemeler beş çeşittir (Resim 50-56). Birincisi, kesişen bir çember ve çarpı şeklinde çizgilerden oluşmaktadır (Çizim 30). İkincisi, kare çerçevede simetri ekseni $45^{\circ}$ olan iki ikizkenar üçgen ve bunların içerisindeki üçer küçük ikizkenar üçgenden ibarettir (Resim 51; Çizim 31). Üçüncüsü, kare çerçevede dört ikizkenar yamuğun birleşmesinden meydana gelen küçük kareden oluşmaktadır. Küçük karenin merkezinde dairesel bir boşluk görülmektedir (Resim 52; Çizim 32). Dördüncüsü, kare çerçevede kesişen çarpı ve eşkenar dörtgenden oluşmaktadır (Resim 53; Çizim "اله", "المنة", "الملك" ve "kelimelerinden ibarettir (Resim 54-56; Çizim 34).

48 Hicr Suresinin 99. ayeti.

49 A'lâ Suresinin 14-15 ayetleri. 


\section{Karşılaştırma}

Bu bölümde, Ardistân Cuma Camii’nde işlenmiş alçı bezemeler, şekil açısından farklı dönemlerdeki benzer örneklerle karşılaştırılacak; bu bezemelerin farklı devirlere ait alçı süslemeler ile benzerlikleri tablolar halinde sunulacaktır. Söz konusu devirler, Sasani dönemi (226-651), İran’ın X. asrı, Abbâsîler Dönemi (Sâmarrâ Şehri / 836-892), Karahanlı dönemi (840-1212), Gazneli dönemi (963-1186), Anadolu Selçuklu dönemi (1075-1308) ve İran’ın İlhanlı (12561353) döneminden ibarettir. Sasani dönemi (Tak-1 Bostan, Bişâpur ve Ktesifon Sarayı arkeolojik sit alanlarından çıkan) alçı sanatının beş örneğinde, Ardistân Cuma Camii'nde bulunan bitkisel süslemelerle benzerlik arz etmektedir (Tablo 1). Nîşâbur şehrine ait (Tepe Medrese ve Sebz Puşan arkeolojik sit alanlarından çıkan) bir bitkisel alçı süsleme örneği ile Ardistân Cuma Camii’nde işlenmiş rumi motiflerin karşılaştırıldığında; benzerlik görülmektedir (Tablo 2). Ardistân Cuma Camii'nde bulunan geometrik ve bitkisel alçı süslemelerin, form açısından Sâmarrâ Şehri'ne ait örnekleri ile benzerliği fark edilmiştir (Tablo 3). Ardistân Cuma Camii'nde işlenmiş bitkisel bezemeler ve kûfi hatlı yazıların, form açısından Gazneli dönemi yapıları, Baba Hatim Türbesi, Leşker-i Bazar Sarayı ve Serdar Tepe Gazneli Sarayı'na ait örneklerle benzerliği görülmektedir (Tablo 3). Ardistân Cuma Camii'nde bulunan kûfi hatlı yazılar, bitkisel ve geometrik bezemeler, İran İlhanlı yapıları, Bestam Kaşane Kulesi, Bestam İmamzâde Muhammed Türbesi, Kum İmamzâde Ahmed b. Kasım Türbesi, Kum Kümbet-i Sebz Türbesi, Sültaniye Kümbeti, İsfahan Cuma Camii ve İsfahan Pir-i Bakran Türbesi’nin bazı alçı süslemeleri ile benzerlik sergilemektedir (Tablo 4-5-6). Ulaşılan sonuçlara göre, Anadolu Selçuklu eserleri, Ahlat Selçuklu Mezar Taşı, Kayseri Sahip Ata (Sahabiye) Medresesi, Mardin Kiziltepe Ulu Camii, Sivas I. Keyknvus Dârüşşifâsı, Sivas Çifte Minareli Medrese, Divriği Ulu Camii, Erzincan Kemah Melik Gazi Türbesi ve Konya Alâeddin Camii’ne ait sülüs ve kûfi hatlı yazılar, bitkisel ve geometrik süslemelerin genel görünümü, Ardistân Cuma Camii'nde bulunan örneklerle benzerlik göstermektedir (Tablo 6-7-8-9). Karahanlılar Dönemi eserleri, Özkent Türbeleri ve Talhatan Baba Camii'nde bulunan bazı süslemeler, Ardistân Cuma Camii’ndeki alçı süslemelerin bazı örnekleri ile benzerlik arz etmektedir (Tablo 9).

\section{Sonuç}

İslam mimarisinde en önemli dini yapı türü sayılan cami, Büyük Selçuklu döneminde zengin alçı süslemeleri barındırmıştır. Büyük Selçuklu dönemi şaheserlerinden sayılan Ardistân Cuma Camii'nde çok zarif ve dikkate değer sanatsal ayrıntılara sahip alçı süsleme ve kitabeler bulunmaktadır. Elde edilen 
sonuçlardan, yapıda Büyük Selçuklu dönemine ait alçı süslemeler, yapının farklı bölümlerinde bulunup, süsleme kompozisyonunun, yazı, bitkisel ve hendesi bezemeleri içerdiği ve kazıma, kabartma ve kalıplama tekniğinde yapıldıkları anlaşılmaktadır.

Ardistân Cuma Camii'ndeki alçı kitabelerin her biri yapılış ve teknik açıdan İslâm mimarisinin tezyînâtında şâheser sayılmaktadır. Kitabeler, dönemin bezeme anlayışına uygun bir şekilde zenginleştirilmiş ve bitkisel kompozisyonlar ile bir arada kullanılmıştır. Buradaki alçı kitabeler, sülüs ve tezyinî kûfi türünde yazilmıştır. Bunlardan tezyinî (müzahref) kûfi kitabeler, muverrek (yapraklı), muakkad (dügümmlü), müşeccer (ağaç gibi dallı budaklı) ve meşrik (doğu) türlere ayırılmaktadır.

$\mathrm{Bu}$ yapıda işlenmiş alçı süslemeler Büyük Selçuklu döneminden önce ve sonraki dönemlere ait süsleme örnekleri ile yakın benzerlikler arz etmektedir. Alçı süslemeler genellikle üslûplaştırılmış yapraklar, kıvrıkdallar, ve sade ve tepelik rumilerin birleşmesiyle meydana gelmişlerdir. Ardistân Cuma Camii'ndeki alçı bezemeler, olağanüstü zengin bitkisel motifler sergilerken, yazı ve bitkisel motifler ile bir arada kullanılan hendesi kompozisyonlar da aynı zenginliği göstermektedir. Hendesi kompozisyonların içerdiği motifler, zencirekler, beş, altı, on altı kollu yıldızlar, altı kollu yıldızlardan müteşekkil hendesi geçmeler, üçgenler ve eşkenar dörtgenlerden ibarettir. Hendesi süslemelere göre daha yoğun olan nebâti düzenlemelere, genellikle mihrapta ve yazılar için zemin oluşturan kûfi ve sülüs kitabelerde rastlanmaktadır.

Büyük Selçuklu döneminin en önemli camilerinden sayılan Ardistân Cuma Camiin güney eyvanında Şafii mezhebinin kurucusu olan İmam Şafii hakkında söylenmiş üç beyitlik bir şiiri ihtiva eden kitabenin yazılması Büyük Selçuklu Devleti'nin dini siyasetteki yönelimini göstermesi açısından dikkat çekicidir. Ayrıca dört eyvanlı camilerden önce dört eyvanlı medreselerin var olduğu ve bazı medreselerdeki her bir eyvan ve ona ait mekânların bir mezhebe (Hanefî, Şâfiî, Mâlikî ve Hanbelî) ait olduğu bilinmektedir. Bu bilgilerden hareketle Ardistân Cuma Camii'nde güney eyvanın Şâfîi mezhebine, öteki eyvanların ise diğer üç mezhebe ait olduğu söylenebilir. Yine bu araştırmanın sonucunda elde edilen bilgiler 1şığında, Ardistân Cuma Camii'nin Büyük Selçuklular döneminde iki aşamada dört eyvanlı hale getirildiğini düşünmekteyiz. Nitekim mihrap önünde beden duvarları üzerinde ve güney eyvandaki tonoz örtünün eteğinde bulunan kitabelerden aynı kanaate ulaşmak mümkündür. Buna göre birinci aşamada (553/1158 tarihte) kubbelerle önündeki sofaların (eyvanların) yapıldığı; ikinci aşamada (555/1160 tarihte) güney eyvanı ile sağdan ve soldan bitişen revakların 
ilave edildiği, sonraki dönemlerde ise yapıya sadece kitabe ve süslemelerin eklendiği söylenebilir.

Olağanüstü zenginliğe sahip olan alçı süslemelerin sanatçıları hakkında bilgi elde edilebilecek kaynaklar oldukça kısıtlıdır. Bahsedilen bu kaynaklar sadece iki kitabeden oluşmaktadır. Ayrıca söz konusu kitabelerde bulunan isimlerin, alçı sanatçıları mı yoksa yapının mimarı mı olup olmadığını anlamak zordur. Fakat caminin güney eyvanında işlenmiş kitabedeki "el- benna" kelimesinin anlamlarına dikkat edilmesi sonucunda, bu ismin büyük bir ihtimal ile yapının mimarı olduğu söylenebilir.

Günümüze ulaşan bu alçı süsleme ve kitabelere bakarak, Büyük Selçuklu alçı süslemelerini yapan sanatçıların mesleklerinde mahir oldukları anlaşılmaktadır. Ayrıca alçı harcının çok çabuk sertleşen ve yapıldıktan sonra da kolayca hasar görebilen bir özelliğe sahip olması, onun ancak tam anlamıyla bir usta elinden çıkması gerektiğini düşündürmektedir.

Araştırmamız neticesinde, Ardistân Cuma Camii'nde bulunan Büyük Selçuklu dönemine ait alçı süslemelerin önceki dönemlere ait benzer nitelikteki eserlerle benzerliği bize Büyük Selçuklu dönemi alçı süsleme sanatçılarının, önceki dönem eserlerinden etkilendiklerini, kendilerine özgü bir tarz oluşturduklarını ve daha sonraki dönemlerin sanatçılarına esin kaynăgı olduklarını göstermektedir. 


\section{Kaynakça}

Arseven, Celal Esad, “Alçı”, Sanat Ansiklopedisi, cilt I, 1983.

Azizpour, Şadabe - Salehi Kakhki, Ahmad, Nukuş ve Ketibehay-i Mesacid-i Cami-i Gülpayegan, Ardistân ve Zevvare, İsfahan, Goldasteh, 1393.

Ayetullâh Zadeh Şirazi, Baker, "Mescid-i Cami-i Ardistân", Eser, cilt I, S. I, Tahran, Sazman-i Miras-i Ferhengi Senayi-i Desti ve Gerdişgeri, 1359 H.Ş.

Balavi, Halid İbn İsa, Tacül-Mefrik fi Tahliyat-ül-ulamâ-il-Meşrik, Riyad, Metba'at Muhammed el-Hamis el-Sakafiye vel-Camiye, 2013.

Dâye Râzî, Necmeddîn, Mirsâdü'l-ibâd, Tahran, Bungâh-i Tercume ve Neşr-i Kitâb, 1351 H.Ş.

Deh-hudâ, Ali Ekber, Lugatnâme, cilt I, Tahran, Müessese-i İntişarat ve Çap-i Danişgâh-i Tahran, 1377 H.Ş.

, Lugatnâme, cilt VIII, Tahran, Müessese-i İntişarat ve Çap-i Danişgâh-i Tahran, 1377 H.Ş.

Dimand, Maurice Sven, A Handbook of Mohammedan Decorative Arts, New York, Metropolitan Museum of Art, 1930.

, Fünûn-ul İslami, Gize, Vekaletıl- Sahafeti'l-Arabiyye, 2018.

En-Nevevi, Ebu Zekeriyya Muhyiddin Yahya b. Şeref, Tehzibu'l-Esmai vel-Lügat, Dımaşk, Darü'l-Feyha, 2013.

Hâfiz-1 Ebrû, Şihâbüddîn Abdullah b. Lutfillâh b. Abdirreşîd-i Bihdâdînî-yi Hâfî, Zübdetü’t Tevârîh, Tahran, Vezaret-i İrşâd-1 İslâmî, 1380 H.Ş.

Hayder Nattaj, Vehid - Maksudi, Mitra, "Mukayese-i Tetbiki Mezamin-i Müşterek-i Giyâhân-i Mukaddes Der Nakşmâyehây-i Giyâhi-i Mimâri Piş Ez İslâm-i İran ve Ârâye-hây-i Mimari Devran-i İslâmi”, Bağ-i Nazar, cilt XVI, S. LXXI, 1398 H.Ş.

Herzfeld, Ernst, Die Ausgrabungen von Samarra, Band VI, Geschichte der Stadt Samarra, Hamburg, Verlag von Sachardt \& Messtorff, 1948.

İbnü'l-Hatib, Ebu Abdullah Lisanüddin Muhammed b. Abdullah, A'malü'lA'lam, cilt I, Beyrut, Darü'l-Kütübi'l-İlmiyye, 2003.

Keyani, Muhammed Yusuf, Tarihi Hunar-i Mimari-i Iran der Devre-i İslami, Tahran, Semt, 1379 H.Ş.

, Isslam Dönemi İran Mimarisi, çev. Kaan Dilek, Muhammet Atmaca, ed. Afsun Nikrevan, I. bs., Ankara, Kültür Bakanlığı, 2018. 
Moshabaki İsfâhâni, Alireza - Sefayi, Nergis, "Berresi-i Tetbiki Giyâhân-i Mukaddes ve Üstûrei Der Hüner-i Sadr-i İslâm ve Piş Ez İslâm (Hehamenişi ve Sâsâni) Ba Tekid Ber Nakş Bercesti-ha”, Mimari-Şinasi, cilt II, S. XII, 1398 H.Ş.

Muhammed, Muhammed ibn, Kitab-ül-Erba in fi İş̧ad-ül-Sa'irin İla Menazil-ül-Muttekin, Beyrut, Darü'l-Kütübi'l-İlmiyye, 1998.

Muin, Muhemmed, Ferheng-i Farsi Mutavassit, Silsila-i Farhangha-yi Muin, cilt I, Tahran, Emir Kebir, 1386 H.Ş.

Mülayim, Selçuk, Değişimin Tanıkları: Ortaçağ Türk Sanatında Süsleme ve İkonografi, İstanbul, Kaknüs Yayınları, 1999.

Nahvi, Muhammed, Ferheng-i Rişei-i Vam-vajehay-i Arabi, Tahran, İntishârât-i İslâmi, 1386 H.Ş.

Otto-Dorn, Katharina, Islamic Art, California, University of California Press, 1976.

Özergin, M. Kemal, “Temürlü Sanatına Ait Eski Bir Belge: Tebrizli Cafer'in Bir Arzı", Sanat Tarihi Yıllı̆̆, S. VI, 1976.

Pencebâşi, Elâhe - Dulâb, Fatemeh, "Mutalee-i Nakş Bercesti-hay-i Giyâhi Sirâf Der Devrei Sâsâni”, Cilve-i Hüner, cilt IX, S. II, 1396 H.Ş.

Raya, Shani, "Stucco Decoration in the Gunbad-i Alewiyyan at Hamadan", ed. R. Hillenbrand, The Art of Seljuqs in Iran and Anatolia, 1994.

Sadr Hâc Seyid Cavâdi, Ahmad, Dâyirat al-meârif-i Tashayyu, cilt II, Tahran, Bunyâd-i İslâmi-i Țâhir, 1365 H.Ş.

Salehi Kakhki, Ahmad, "Pezhuheşi Ber Tezyinat-i Mimari-i Devre-i Gaznevi”, Feslnâme-i Pezhhişhây-i Târihi, cilt IX, S. IV, 1396 H.Ş.

Upham Pope, Arthur, Mimari-yi Iran, çev. Golamhüseyn Sadri, Urumîye, Neşr-i Enzeli, 1363 H.Ş.

Üveys, Seyyid, Resail ela al-Imam el-Şafii: Zahiret Irsal el-Resail ela Derii el-İmam el-Şafii, Kahire, Dar-ül Şayi, 1978.

Wilkinson, Charles J., Nishapur: Some Early Islamic Buildings and Their Decoration. New York, The Metropolitan Museum of Art, 1986.

\section{Internet Kaynakları}

“Kur'an-1 Kerim Portalı”, Diyanet İşeri Başkanlığı Kur'an-ı Kerim Portalı, Son Erişim: 3 Temmuz 2020, https://kuran.diyanet.gov.tr/. 
https://www.kavehfarrokh.com/military-history-1900-present/jens-kroger-ctesiphon/

https://www.metmuseum.org/art/collection/search/322639

https://www.metmuseum.org/art/collection/search/322673

https://www.metmuseum.org/art/collection/search/449951

https://universes.art/en/art-destinations/berlin/museum-of-islamic-art/photo-tour/samarra-wall-coverings

http://www.unesco.org/culture/museum-for-dialogue/item/en/216/glazed-hexagonal-moulded-tile

https://archnet.org/sites/3923/media_contents/144310

https://unora.unior.it/retrieve/handle/11574/160922/61920/Filigenzi\%20Giunta $\% 20$ Safeguarding $\% 20$ Cultural $\% 20$ Heritage $\% 20$ in $\% 20$ Post-Conflict $\% 20$ Afghanistan.pdf

https://seyahatdergisi.com/sahabiye-medresesi-nerede-tarihi-ve-hakkinda-bilgi/

https://scontent.ftzx 1-1.fna.fbcdn.net/v/t1.0-9/

http://www.photo.kg/uploads/posts/2015-08/1439989994_img_2535.jpg 


\section{Resim, Çizim ve Tablolar ${ }^{50}$}

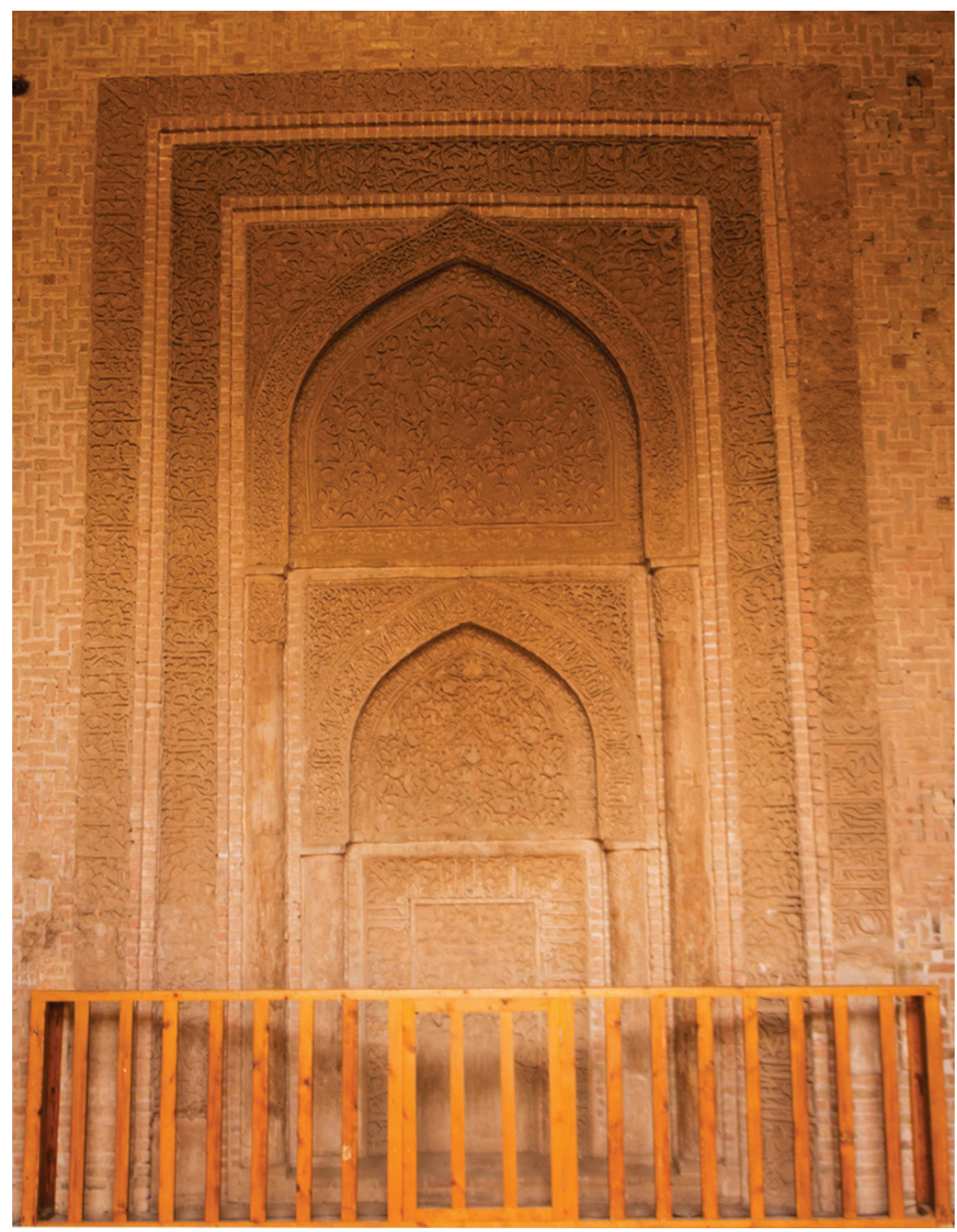

Resim 1. Ardistân Cuma Cam ii Asıl Mihrabı Genel Görünümü

50 Kaynağı belirtilmeyen resimler yazara aittir. 


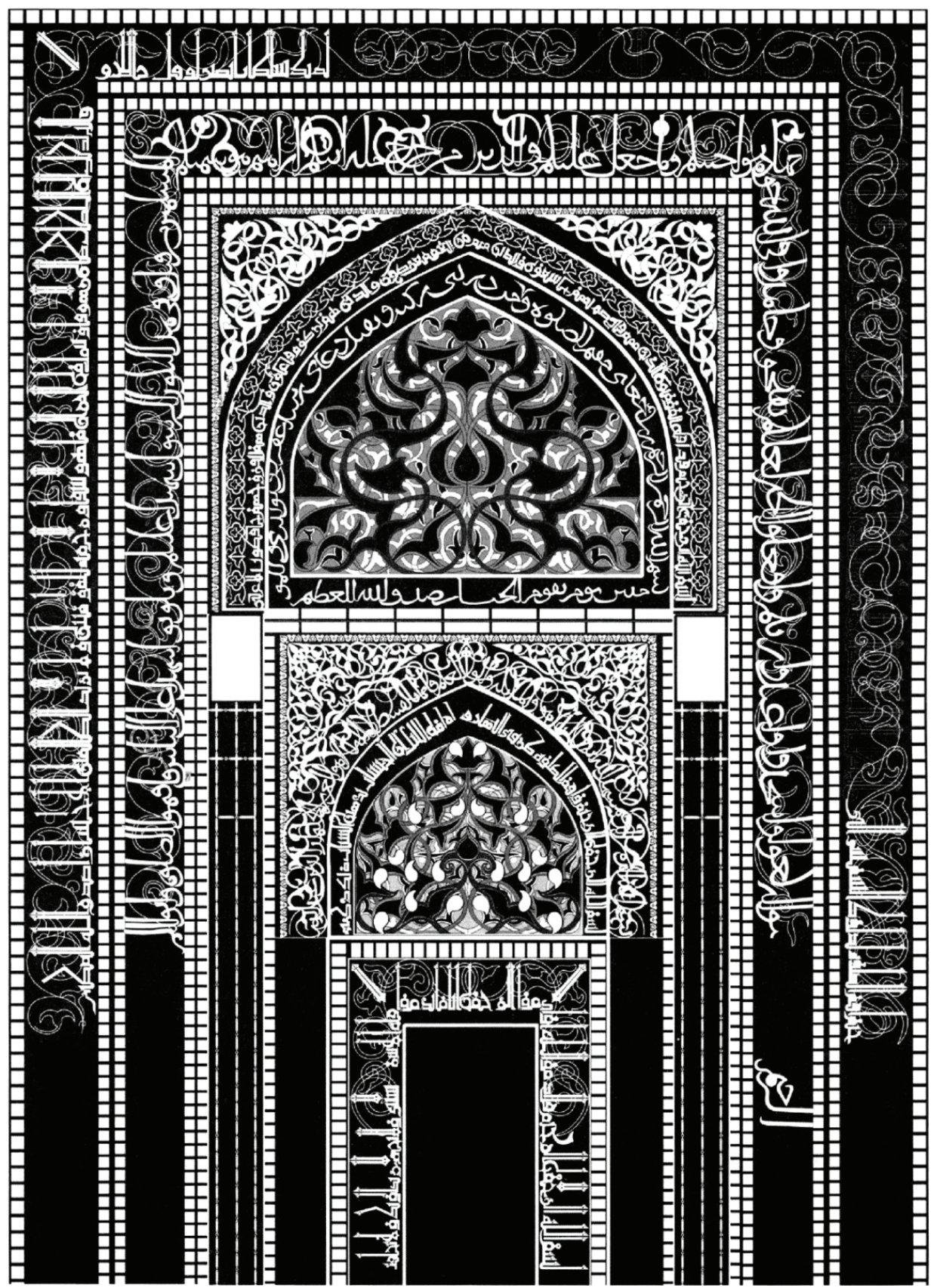

Çizim 1. Ardistân Cuma Camii Mihrabı Genel Görünümü (Azizpour’dan) 


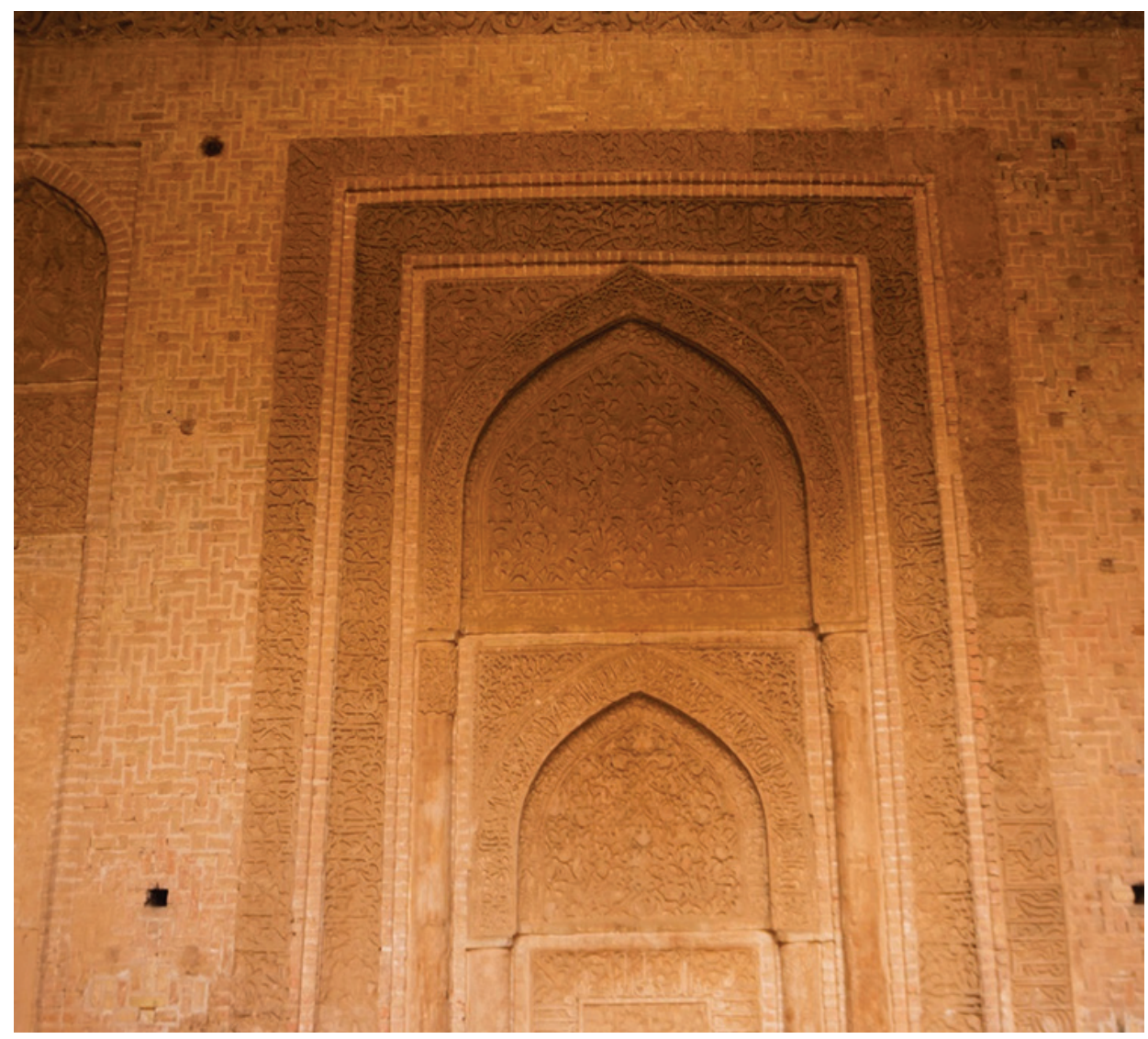

Resim 2. Ardistân Cuma Camii Asıl Mihrabından Ayrıntı

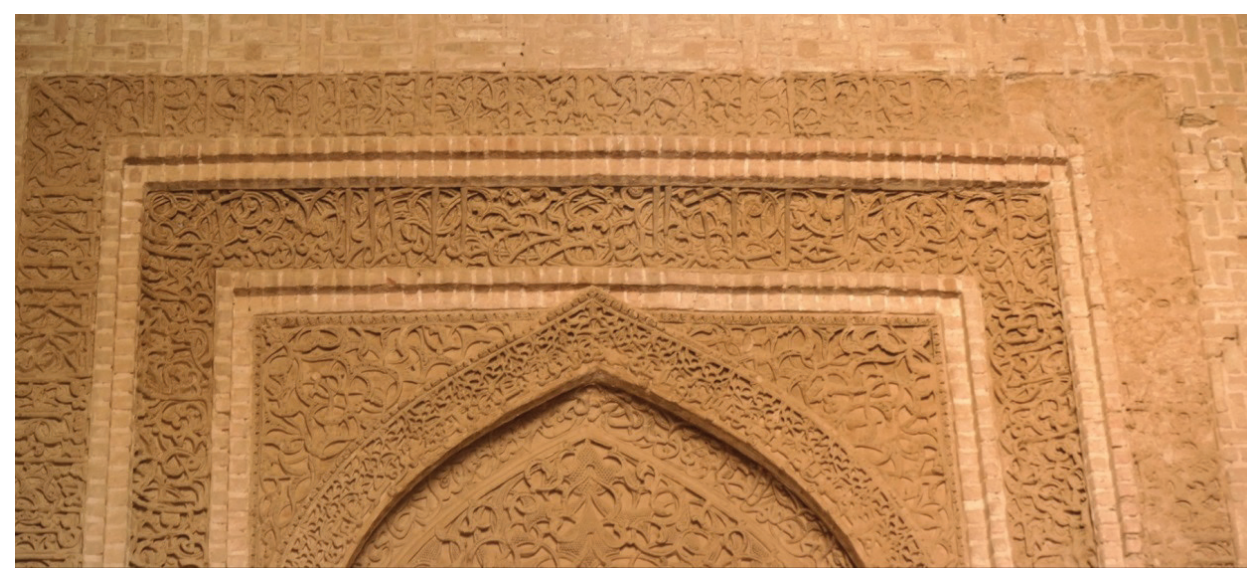

Resim 3. Ardistân Cuma Camii Asıl Mihrabı Kûfi Yazı Çerçevesinden Ayrıntı 


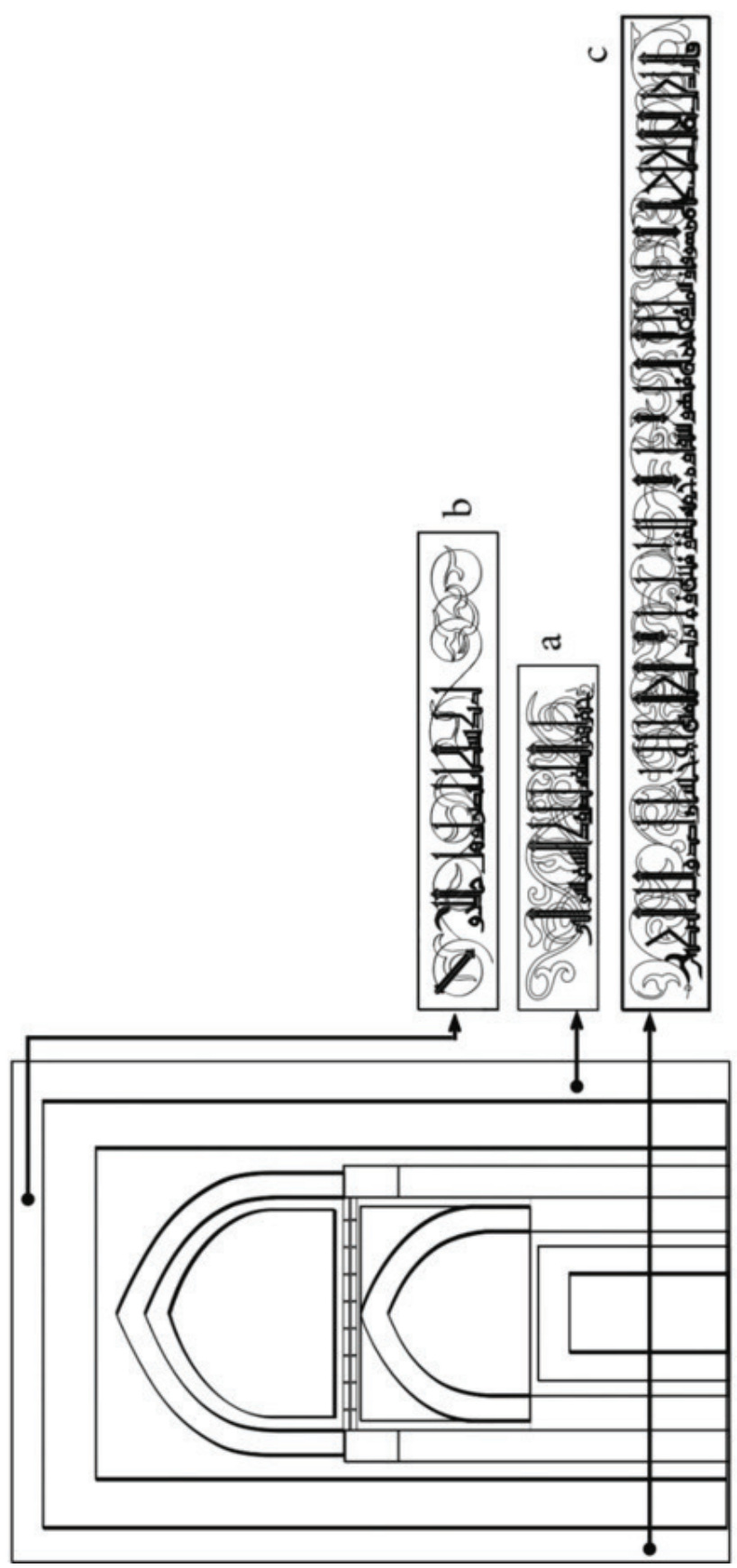

Çizim 2. Ardistân Cuma Camii Mihrabı Kûfi Yazı Çerçevesi (Azizpour'dan) 

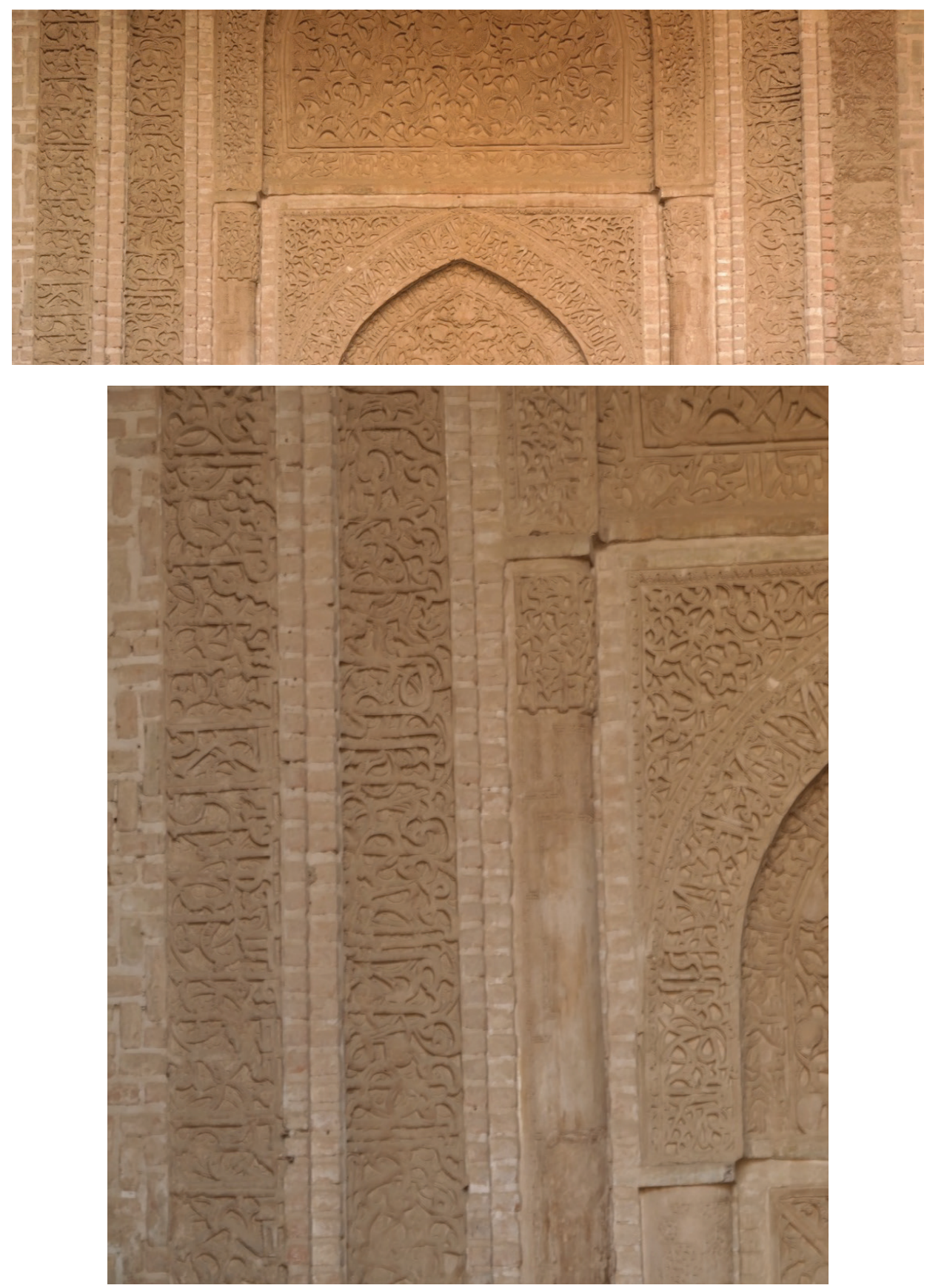

Resim 4. Ardistân Cuma Camii Asıl Mihrabı Sülüs Yazı Çerçevesinden Ayrıntılar 


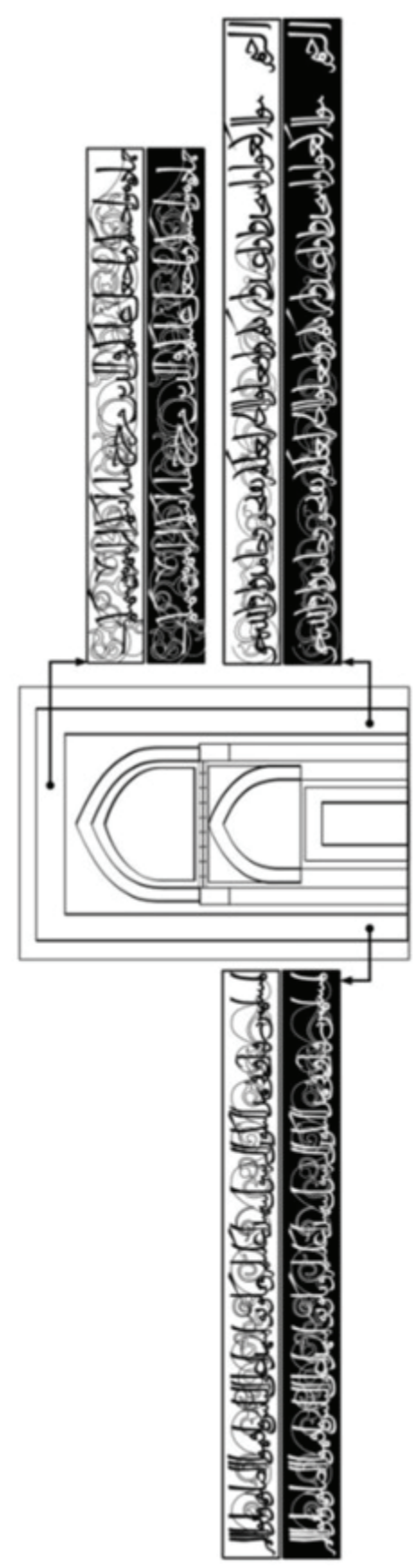

Çizim 3. Ardistân Cuma Camii Mihrabı Sülüs Yazı Çerçevesinde Bulunan Kitabe ve Süslemeler (Azizpour'dan) 


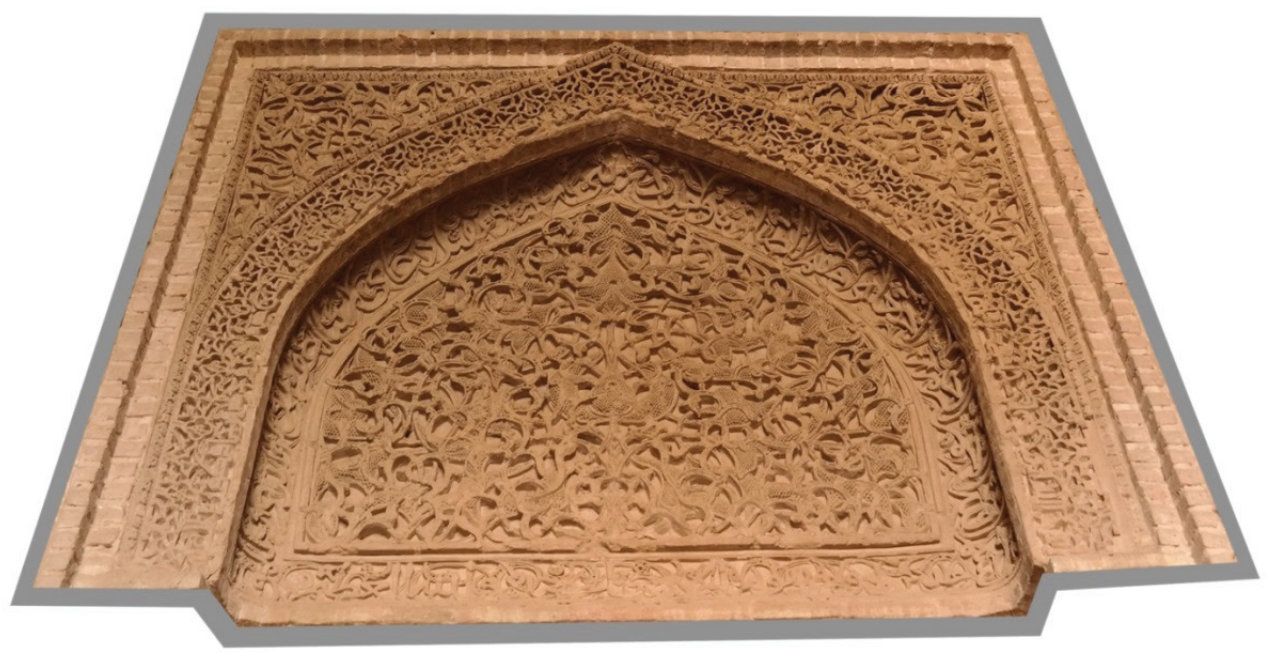

Resim 5. Ardistân Cuma Camii’nin Mihrabının Kavsarası, Kavsara Kuşatma Kemeri ve Kavsara Köşelikleri

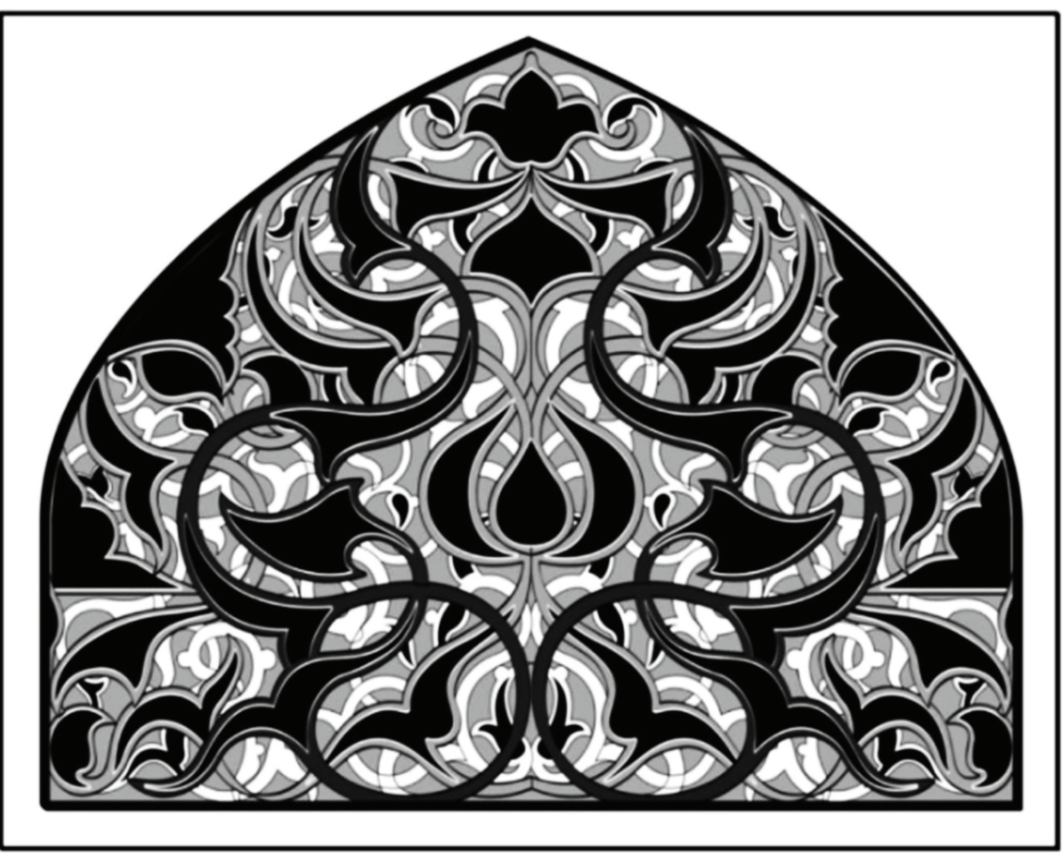

Çizim 4. Ardistân Cuma Camii Mihrap Kavsarası (Azizpour'dan) 


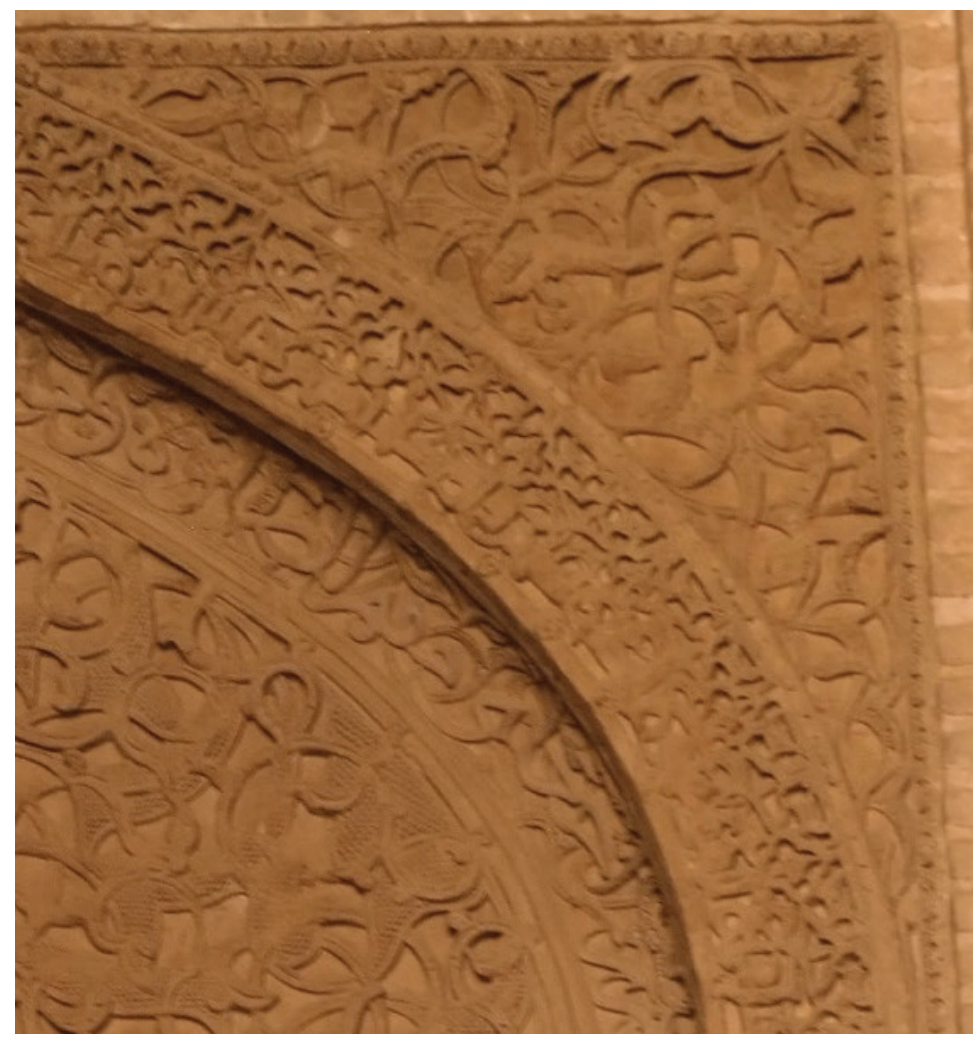

Resim 6. Ardistân Cuma Camii Asıl Mihrap Kavsara Köşelikleri
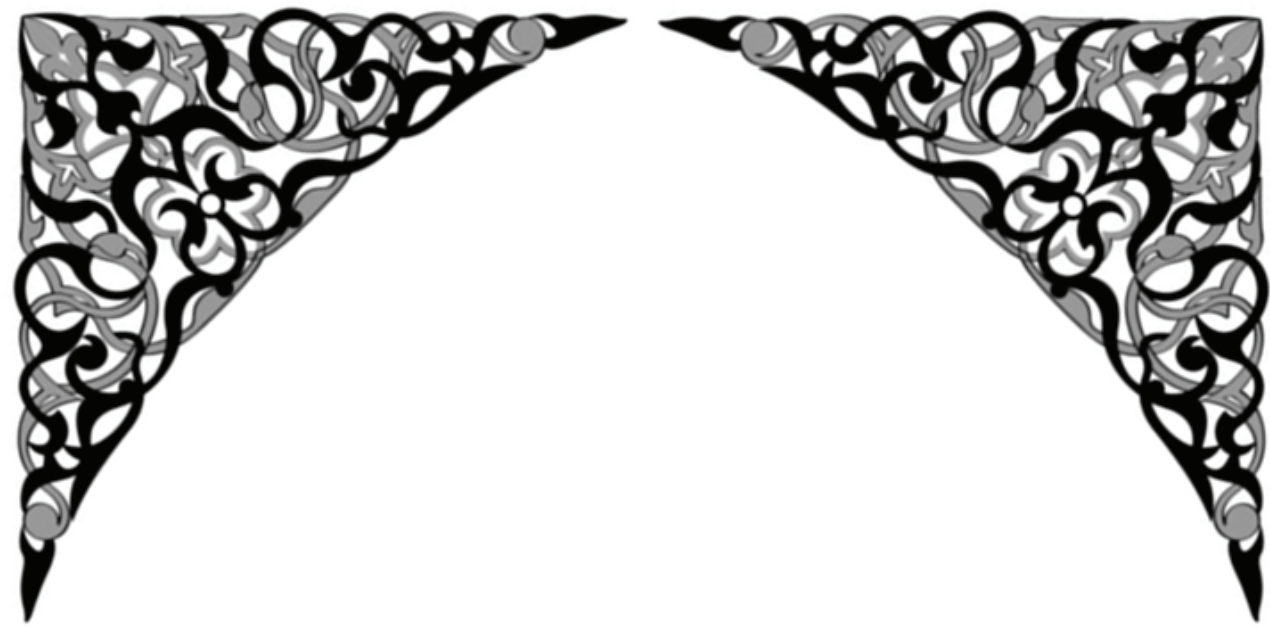

Çizim 5. Ardistân Cuma Camii Mihrap Kavsara Köşelikleri (Azizpour’dan) 


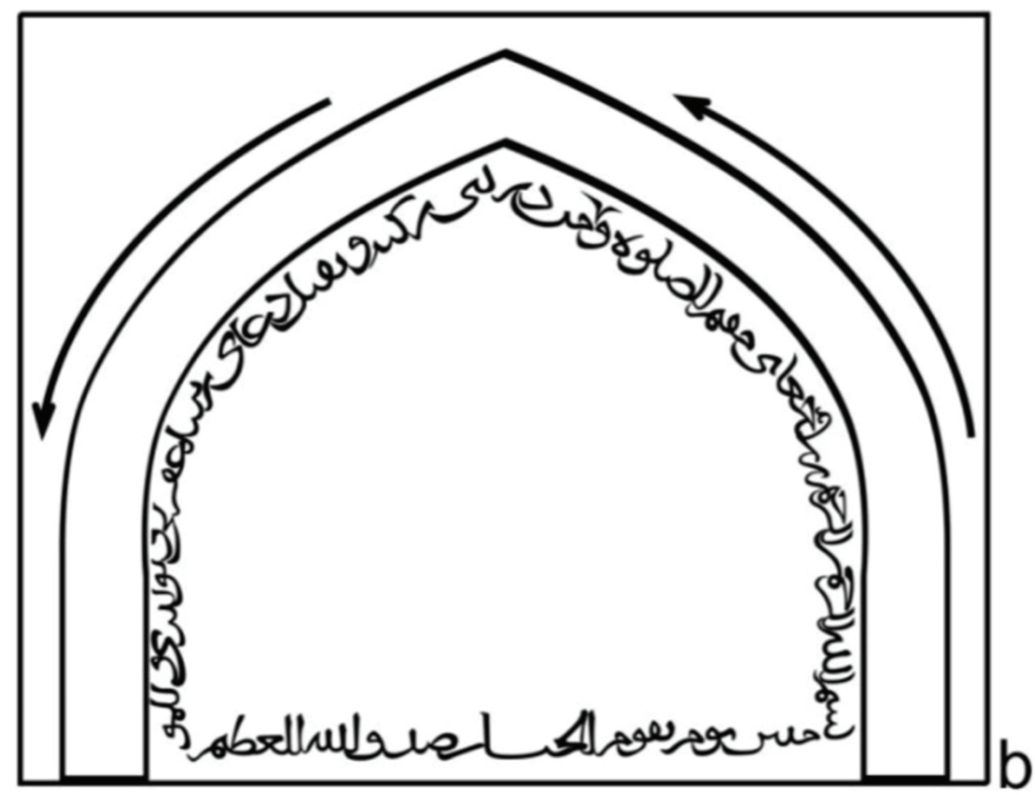

Çizim 6. Ardistân Cuma Camii'nin Mihrabının Kavsarasını İçten Sınırlayan Sivri Kemerli Yazı Bordürünün Çizimi (Azizpour'dan)

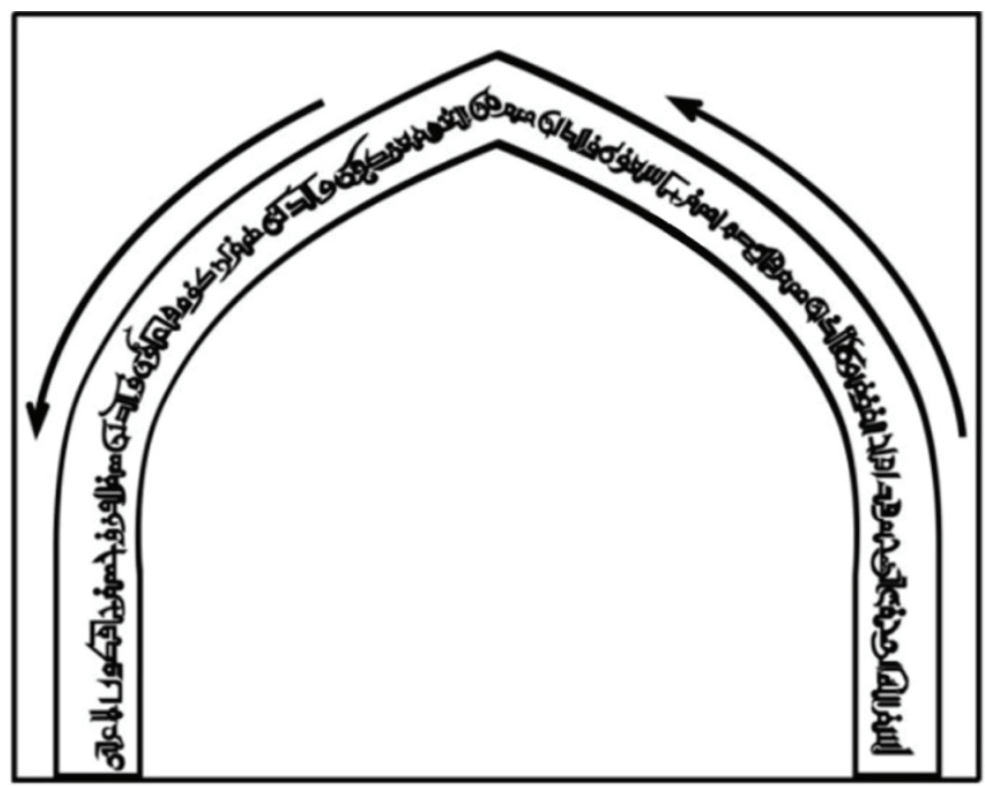

Çizim 7. Ardistân Cuma Camii Mihrabı Kavsara Kuşatma Kemeri Yüzeyindeki Kitabe (Azizpour'den) 


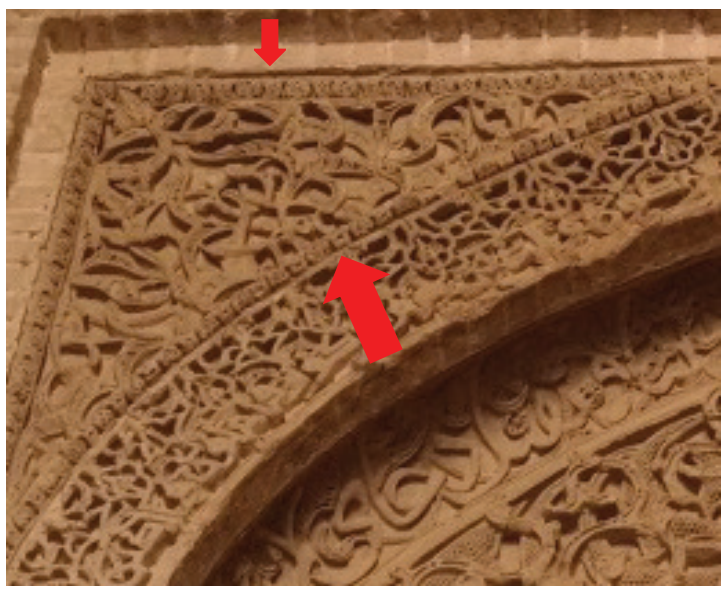

Resim 7. Ardistân Cuma Camii Asıl Mihrap Kavsara Bölümündeki Süslemeler

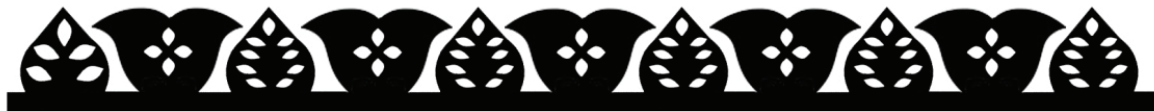

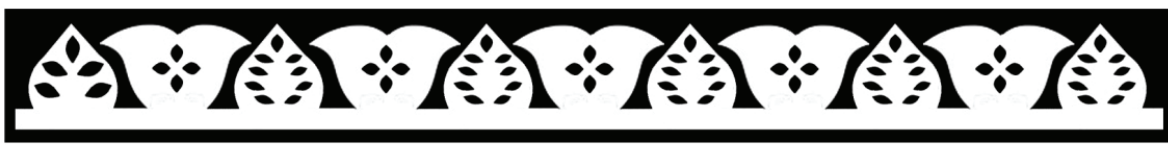

Çizim 8. Ardistân Cuma Camii Mihrabı Kavsara Kuşatma Kemeri ve Kavsara Köşeliklerini Çerçeveleyen Süsleme Şeridi
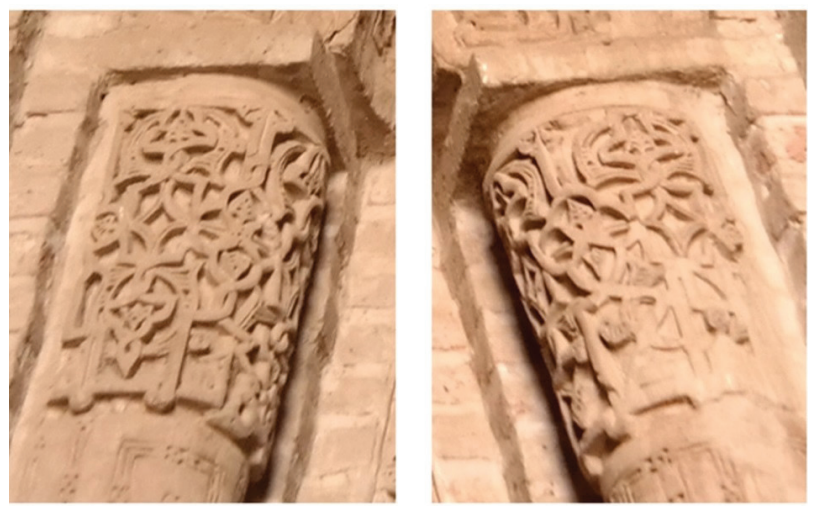

Resim 8. Ardistân Cuma Camii Asıl Mihrabı Sütunce Başlıkları 

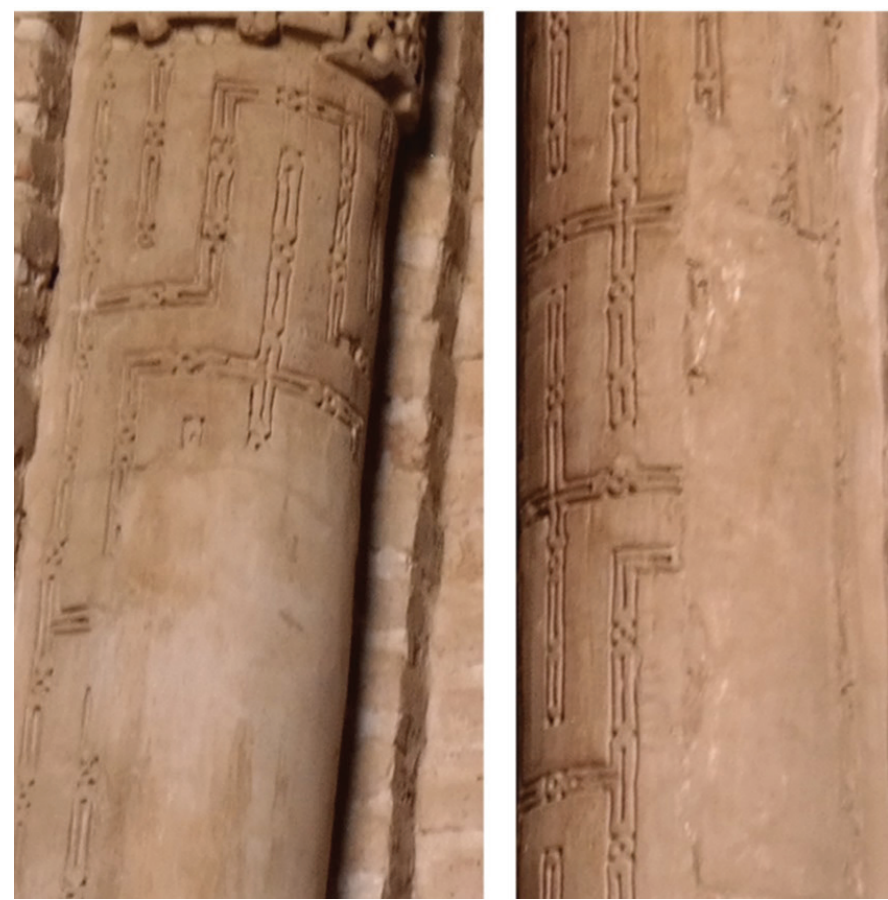

Resim 9. Ardistân Cuma Camii Asıl Mihrabı Sütunce Gövdeleri

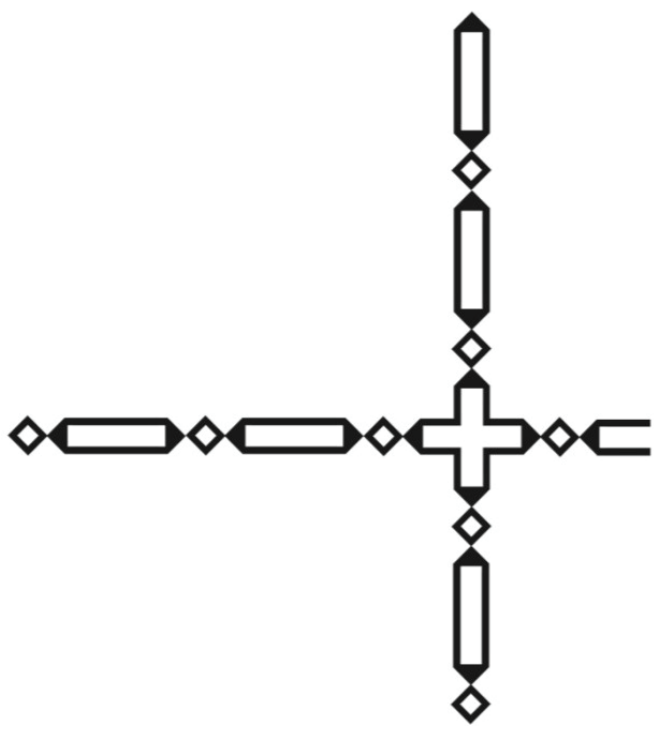

Çizim 9. Ardistân Cuma Camii Mihrabı Sütunce Gövdelerindeki süsleme detayı 


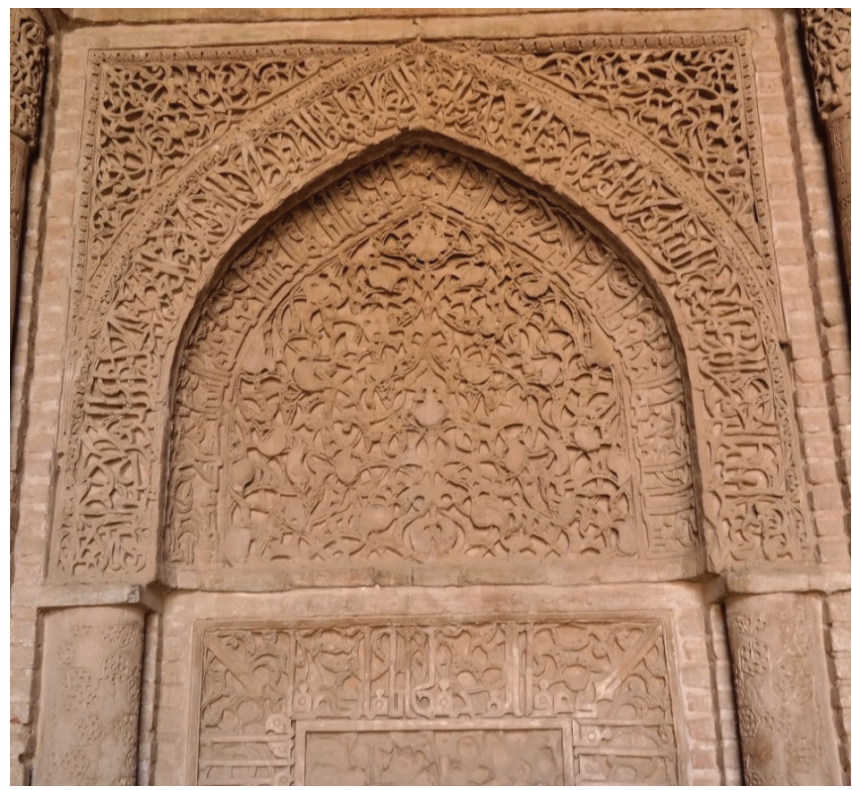

Resim 10. Ardistân Cuma Camii Asıl Mihrap Nişinden Ayrıntı

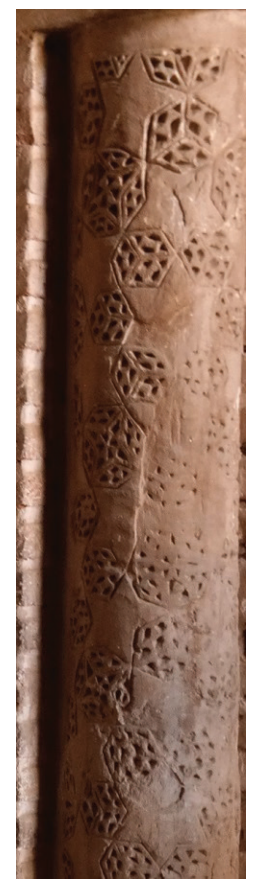

Resim 11. Ardistân Cuma Camii Asıl Mihrap Nişindeki Sütunce Gövdeleri 


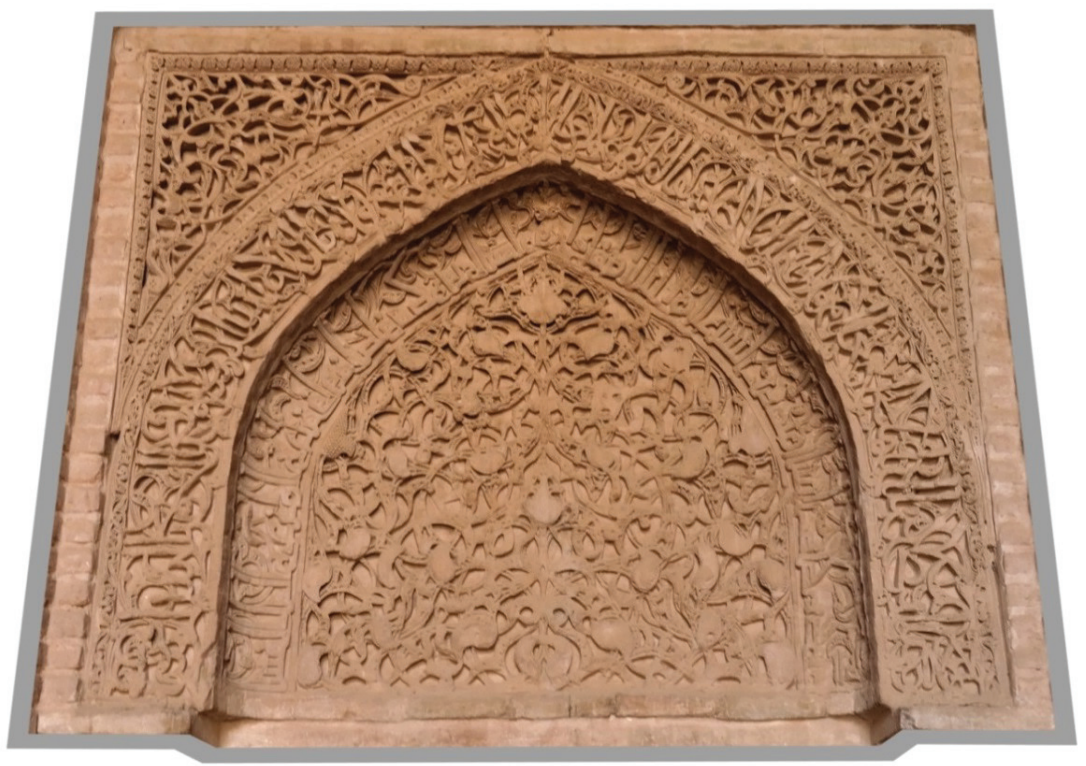

13

Resim 12. Ardistân Cuma Camii Asıl Mihrap Nişinden Ayrıntı

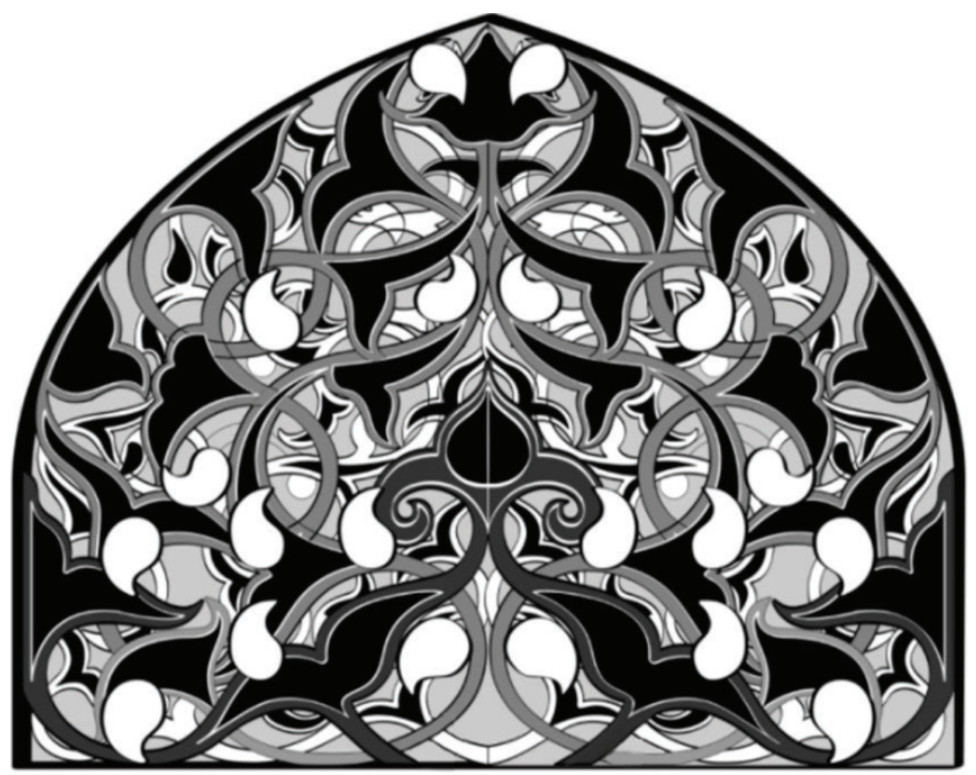

Çizim 10. Ardistân Cuma Camii Mihrap Nişindeki Kemerin İçerisinde İşlenen Süslemeler (Azizpour'dan) 


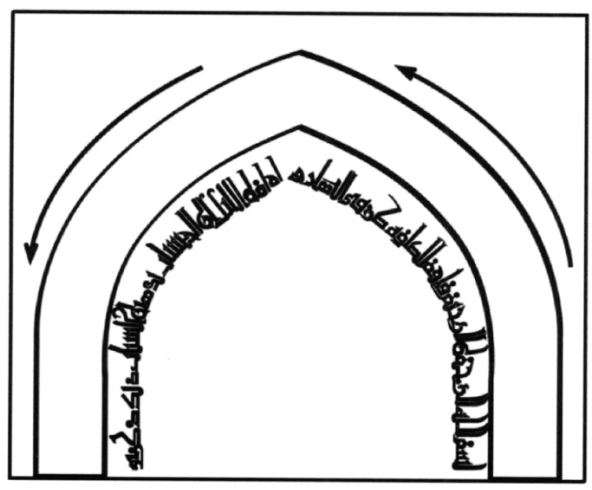

Çizim 11. Ardistân Cuma Camii Mihrap Nişindeki Kemerin İçerisinde İşlenen Süslemeleri Sınırlayan Süslemeli Şerit (Azizpour'dan)

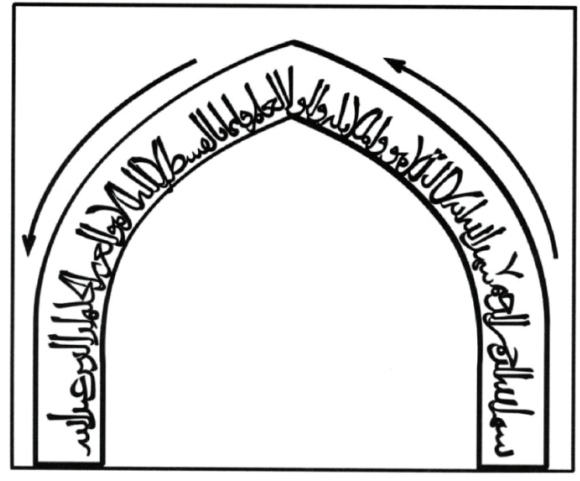

Çizim 12. Ardistân Cuma Camii Mihrap Nişi

Kemerinin Yüzeyindeki Kitabe (Azizpour'dan)

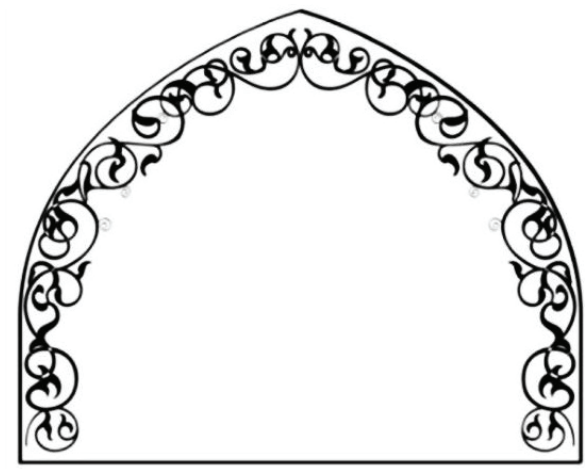

Çizim 13. Ardistân Cuma Camii Mihrap Nişi

Kemerinin Süslemeleri (Azizpour'dan) 


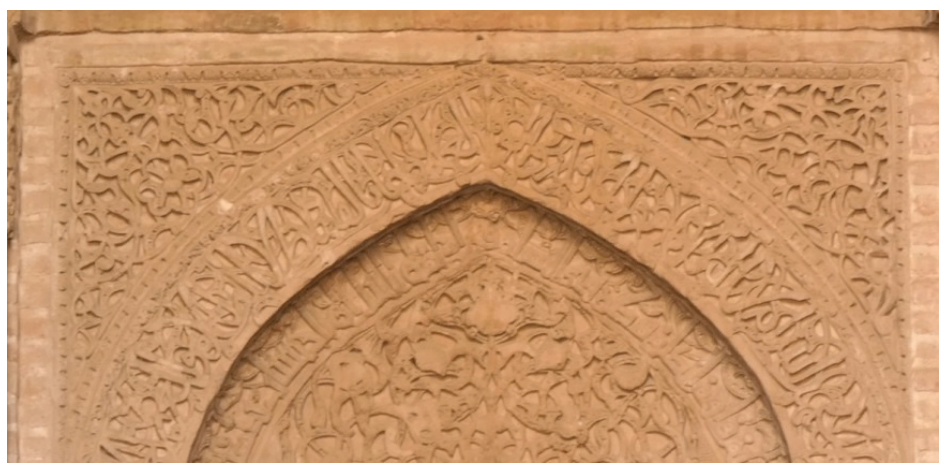

Resim 13. Ardistân Cuma Camii Asıl Mihrap Nişindeki Kemer Köşelikleri

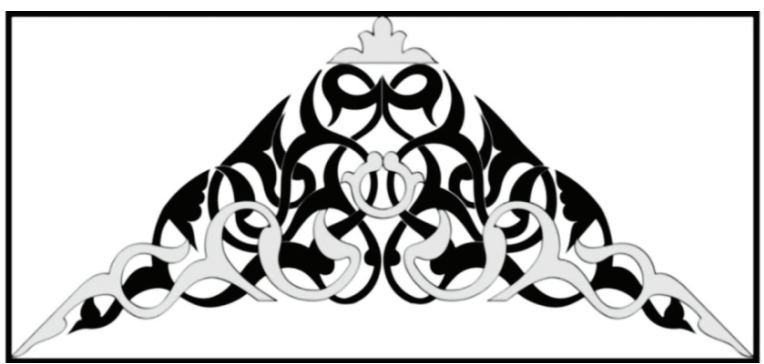

Çizim 14. Ardistân Cuma Camii Mihrap Nişindeki Kemer Köşelikleri (Azizpour'dan)

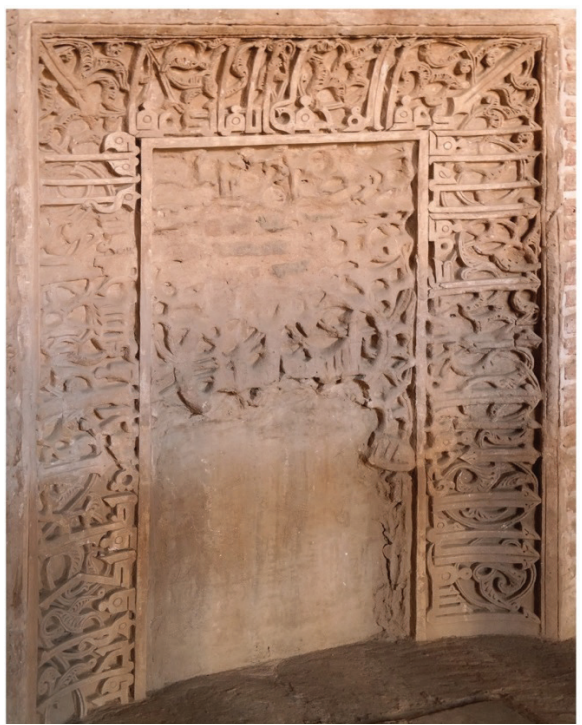

Resim 14. Ardistân Cuma Camii Asıl Mihrap Nişindeki Kûfi Yazı Bordürü 


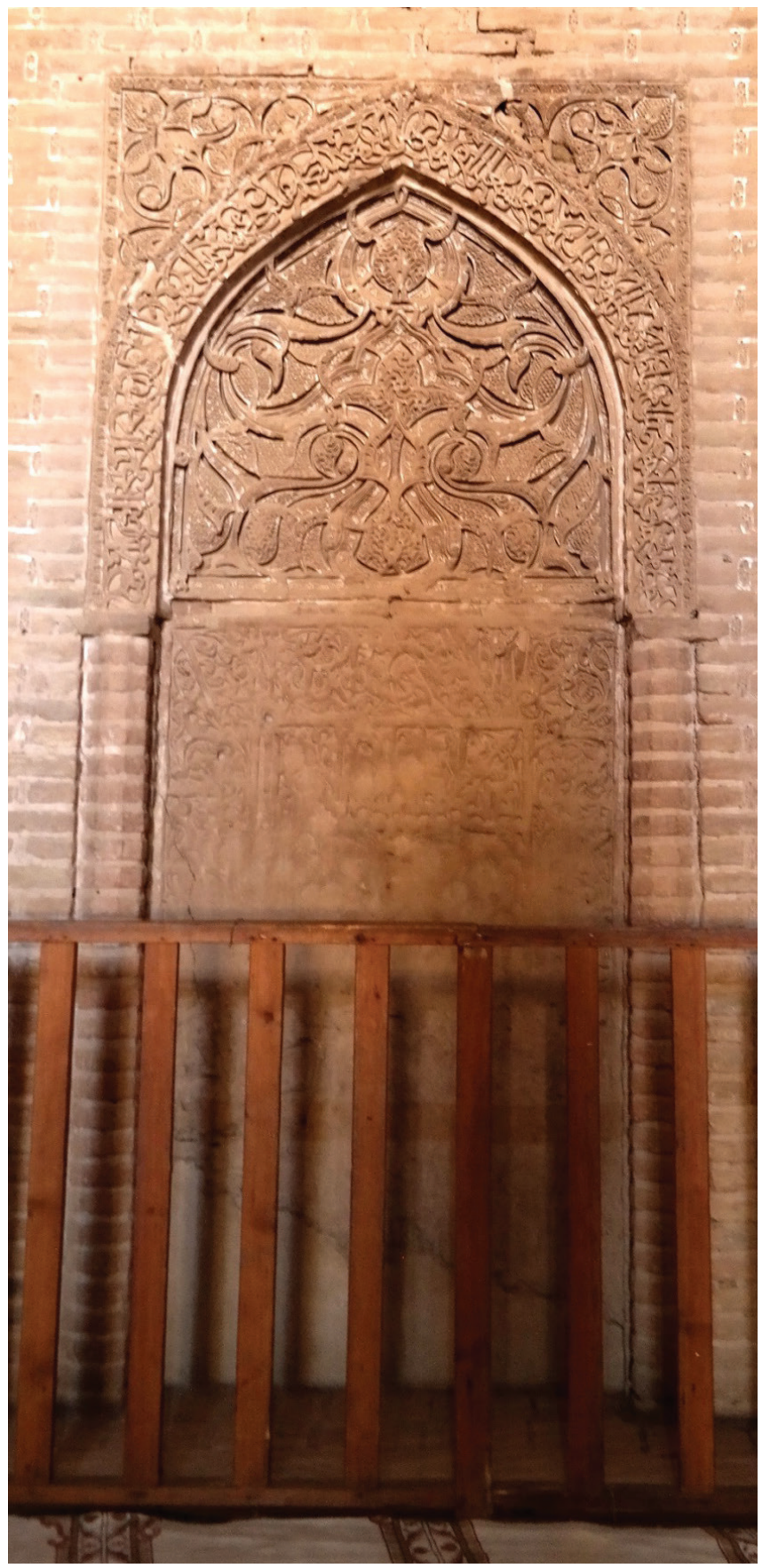

Resim 15. Ardistân Cuma Camii İkinci Mihrabı Genel Görünümü 


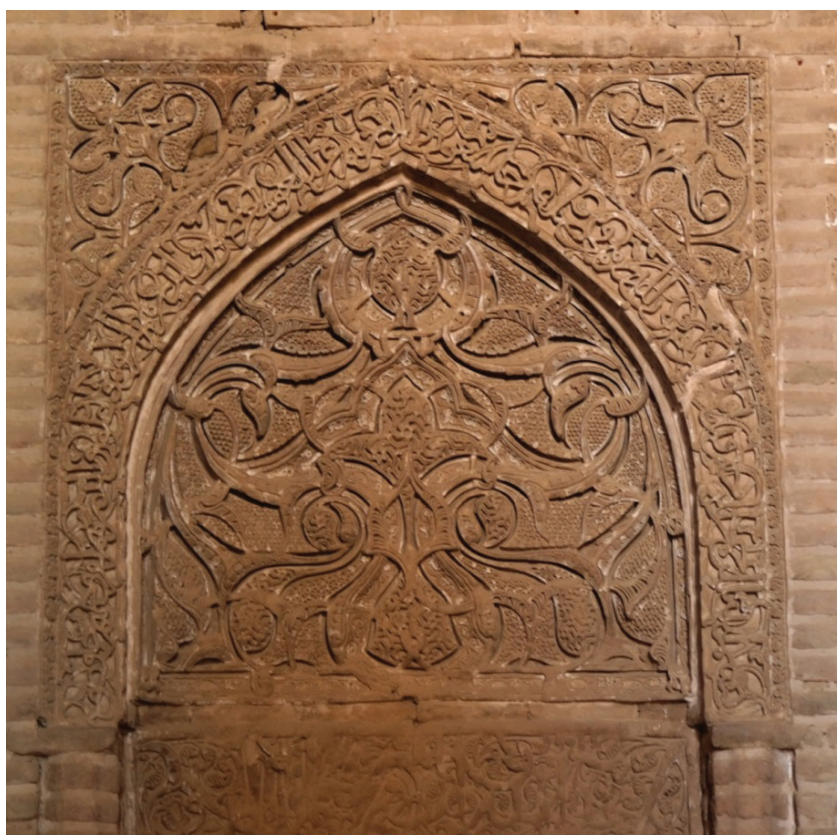

Resim 16. Ardistân Cuma Camii İkinci Mihrabından Ayrıntı

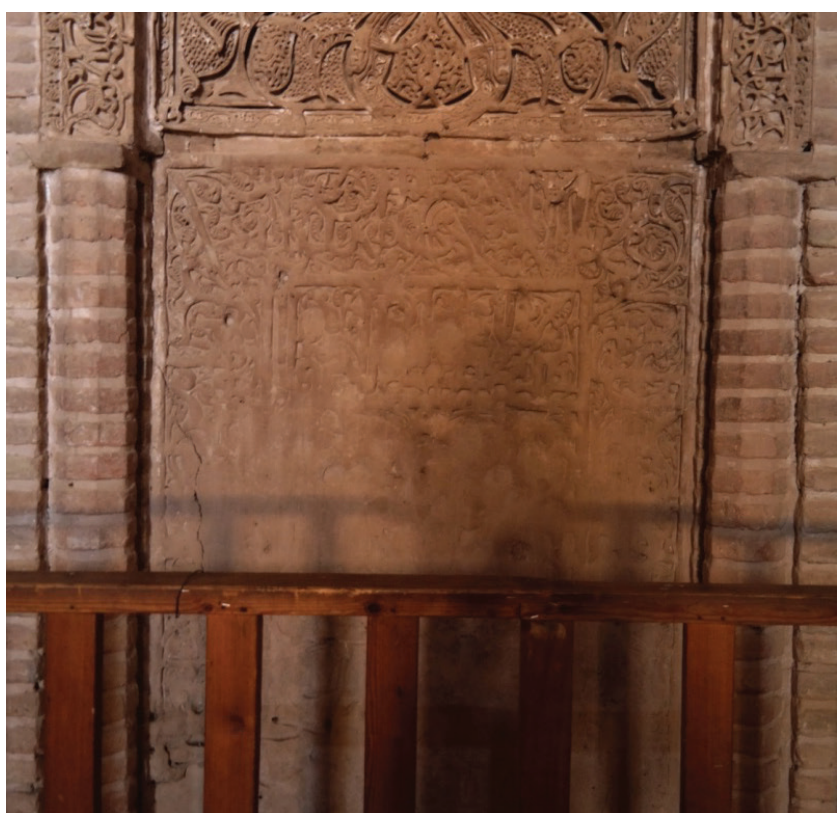

Resim 17. Ardistân Cuma Camii İkinci Mihrabından Ayrıntı 


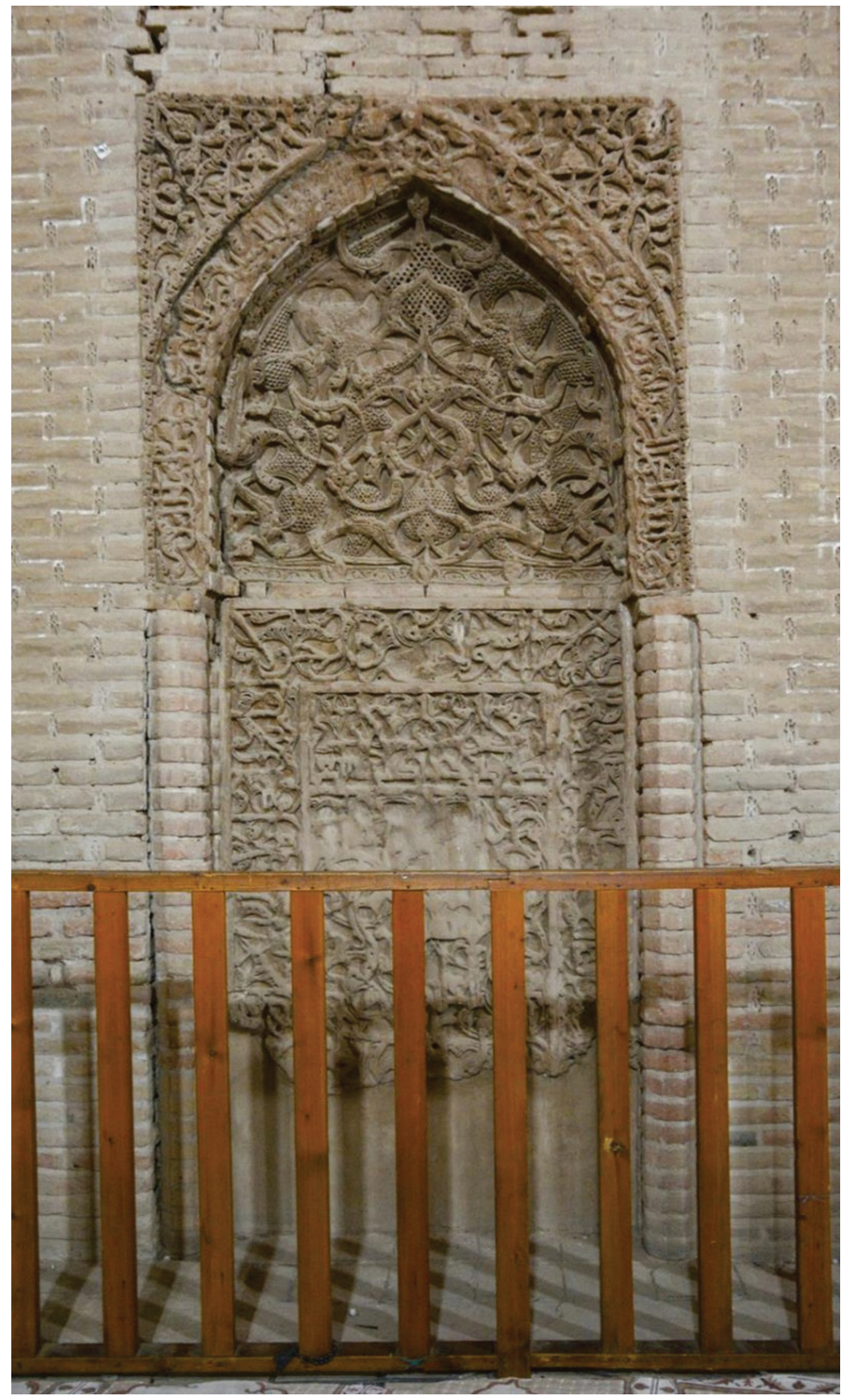

Resim 18. Ardistân Cuma Camii Üçüncü Mihrabı Genel Görünümü 


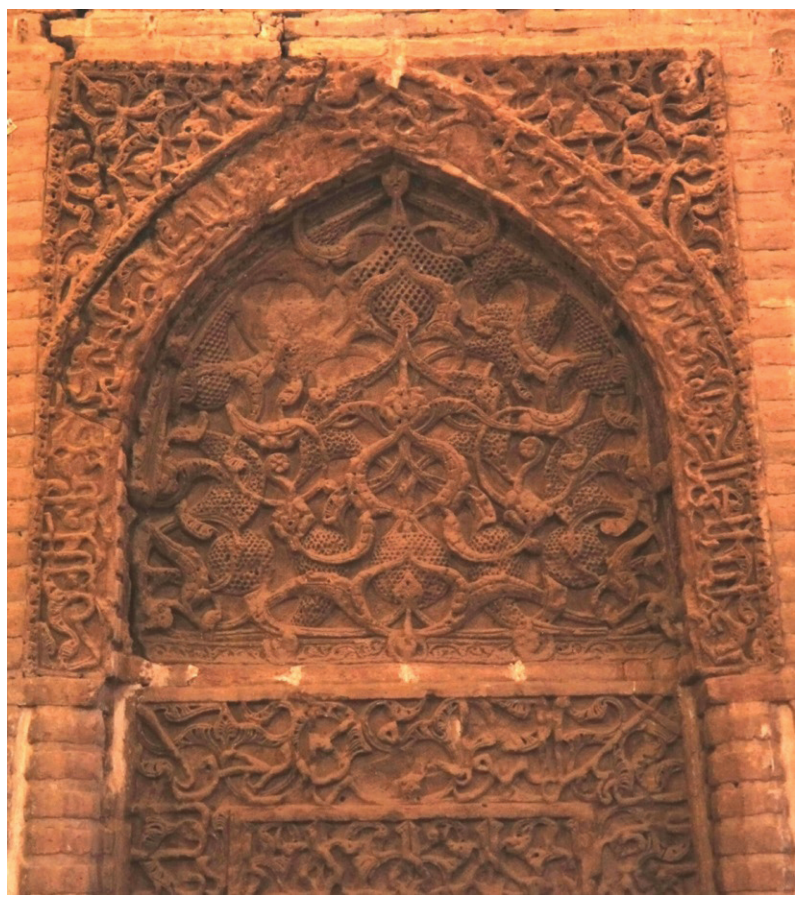

Resim 19. Ardistân Cuma Camii Üçüncü Mihrabından Ayrıntı

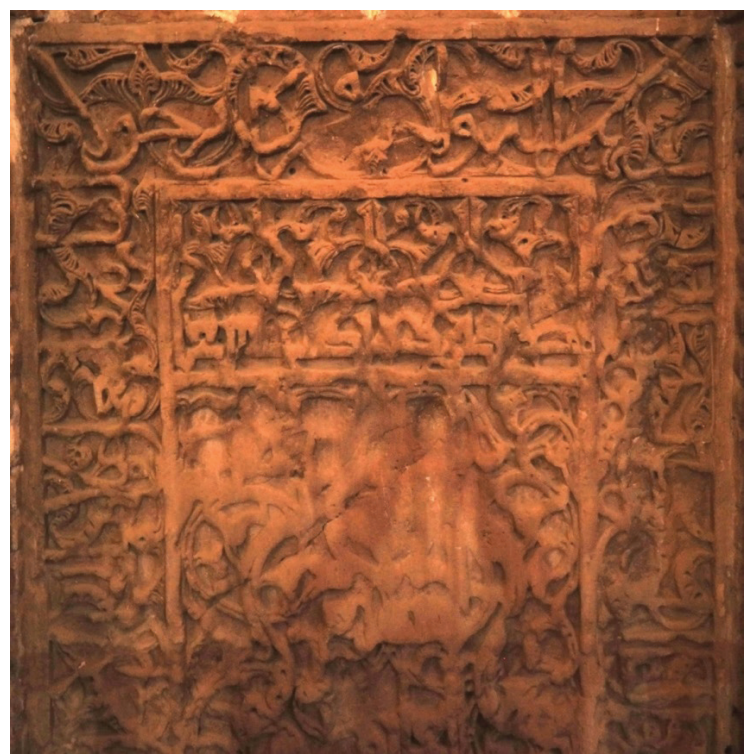

Resim 20. Ardistân Cuma Camii Üçüncü Mihrabından Ayrıntı 


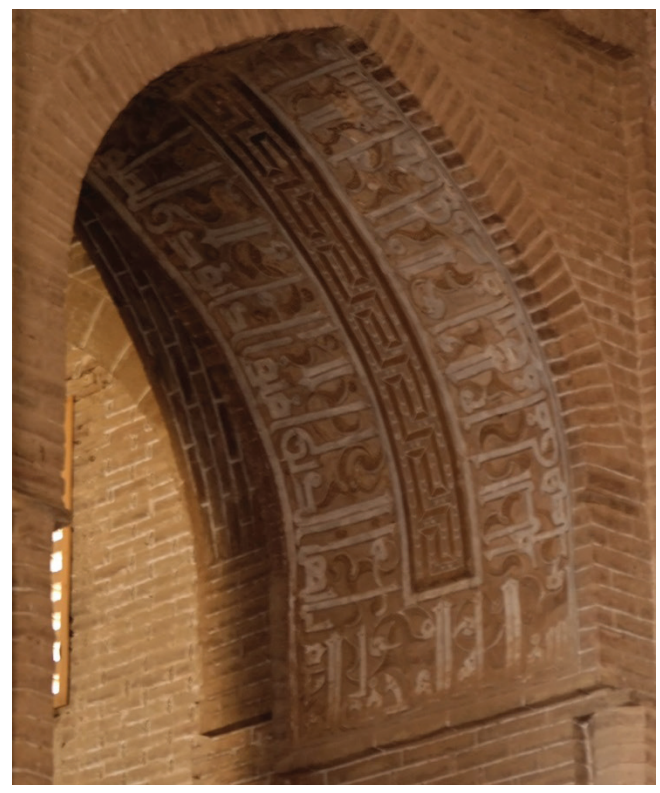

Resim 21. Ardistân Cuma Camii Asıl Mihrabın Doğusundaki I. Kemerin Kitabe ve Süslemelerinden Ayrıntı

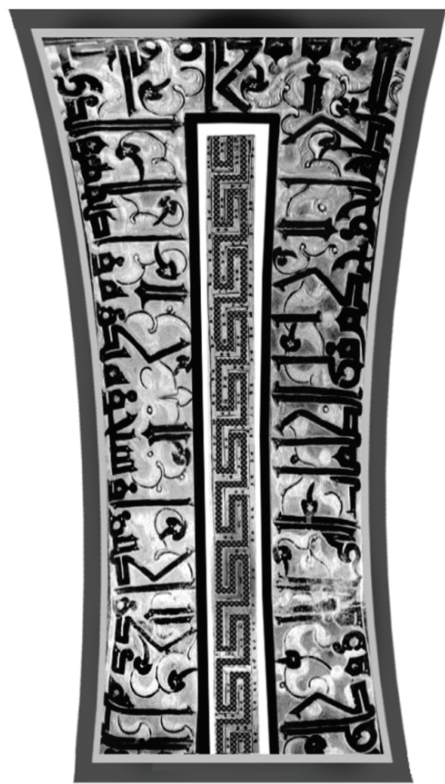

Çizim 15. Ardistân Cuma Camii Asıl Mihrabın Doğusundaki I. Kemerin Kitabe ve Süslemeleri 


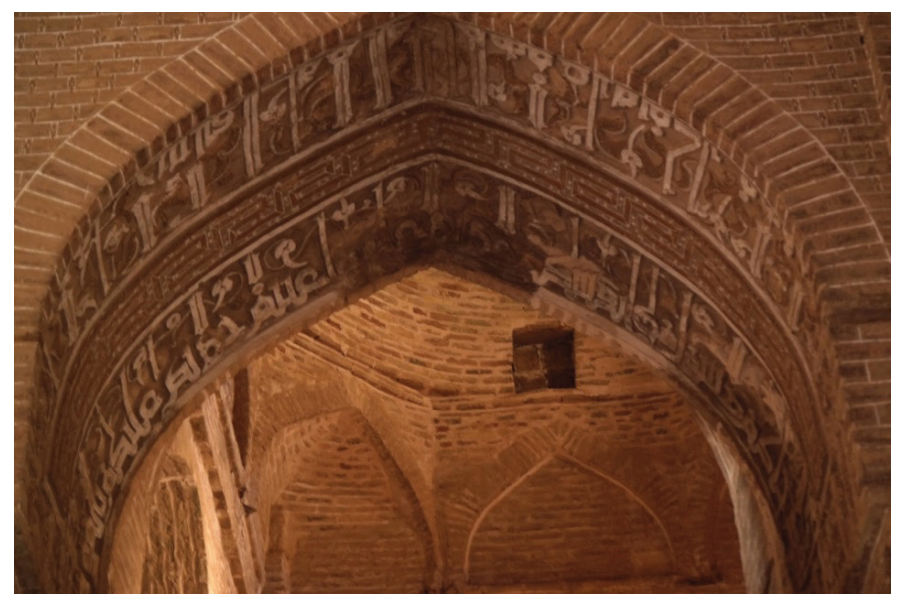

Resim 22. Ardistân Cuma Camii Kubbeli Mekândaki III. Kemerin Kitabe ve Süslemeleri

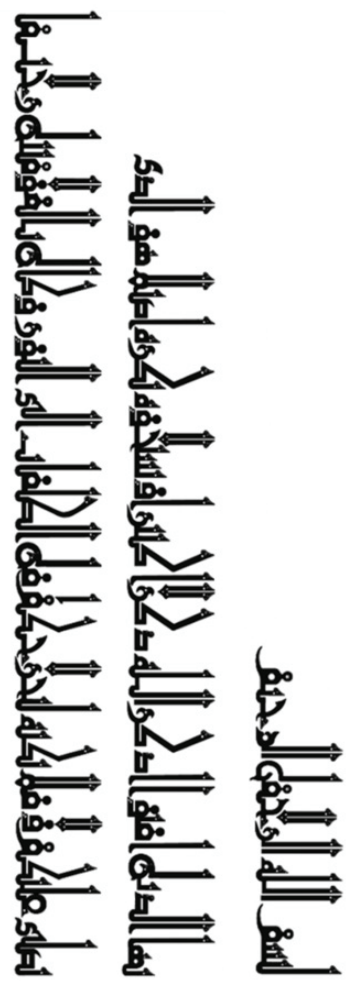

Çizim 16. Ardistân Cuma Camii Kubbeli Mekândaki II. Kemerin Kitabe ve Süslemeleri (Azizpour'den) 


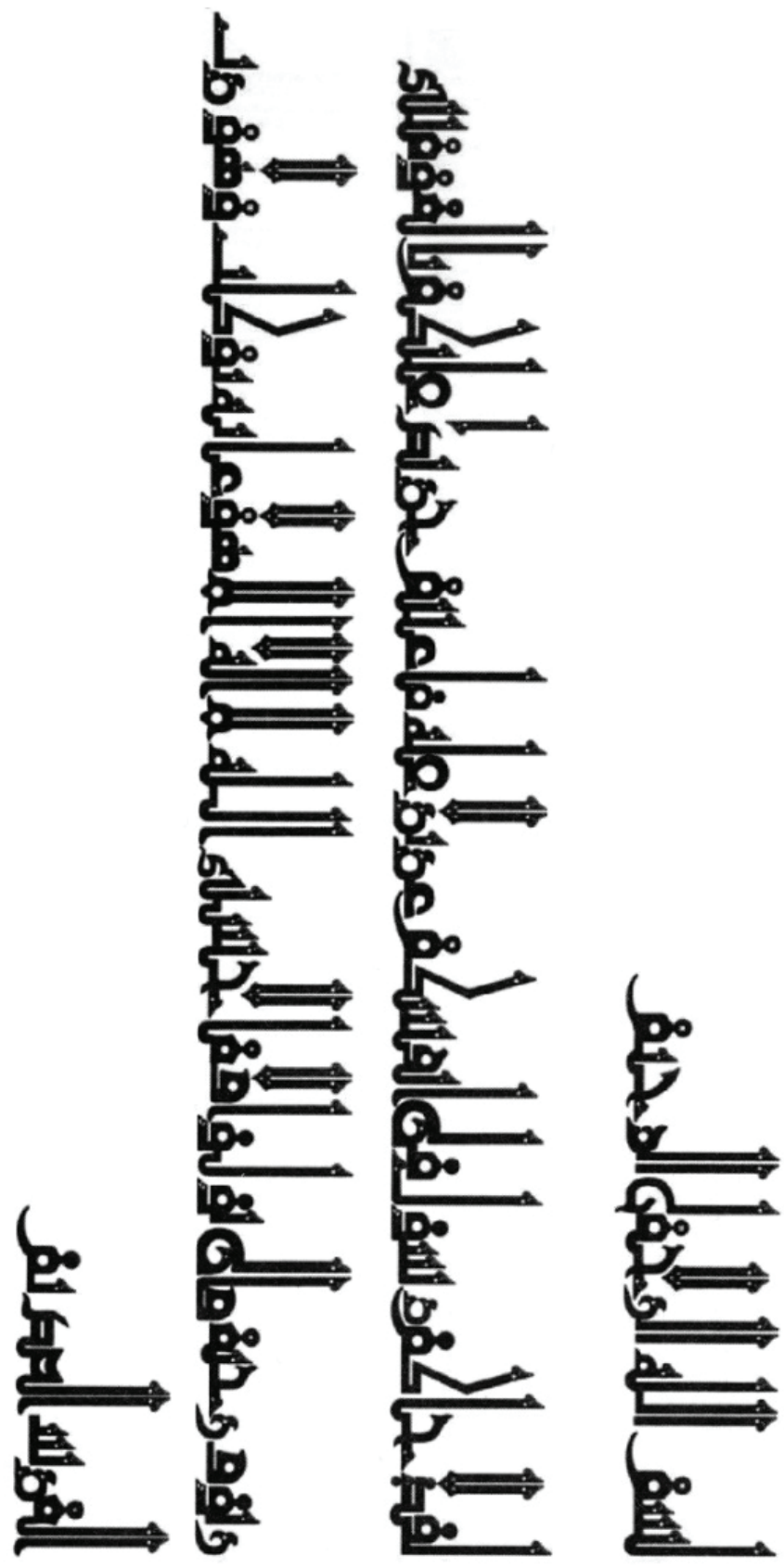

Çizim 17. Ardistân Cuma Camii Kubbeli Mekândaki III. Kemerin Kitabe ve Süslemeleri (Azizpour'dan) 


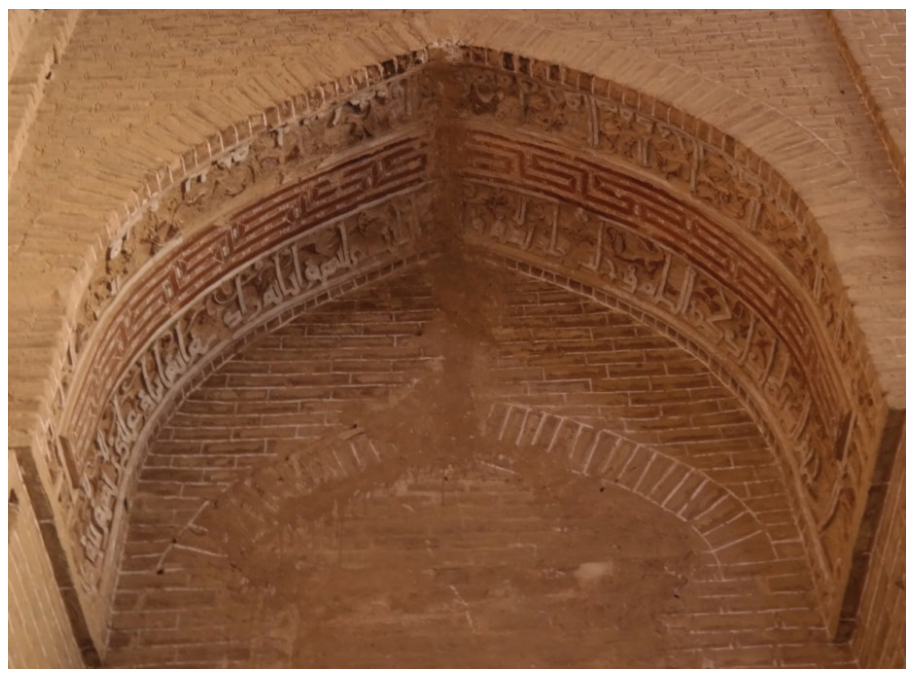

Resim 23. Ardistân Cuma Camii Asıl Mihrabın Batısındaki IV. Kemerin Kitabe ve Süslemeleri
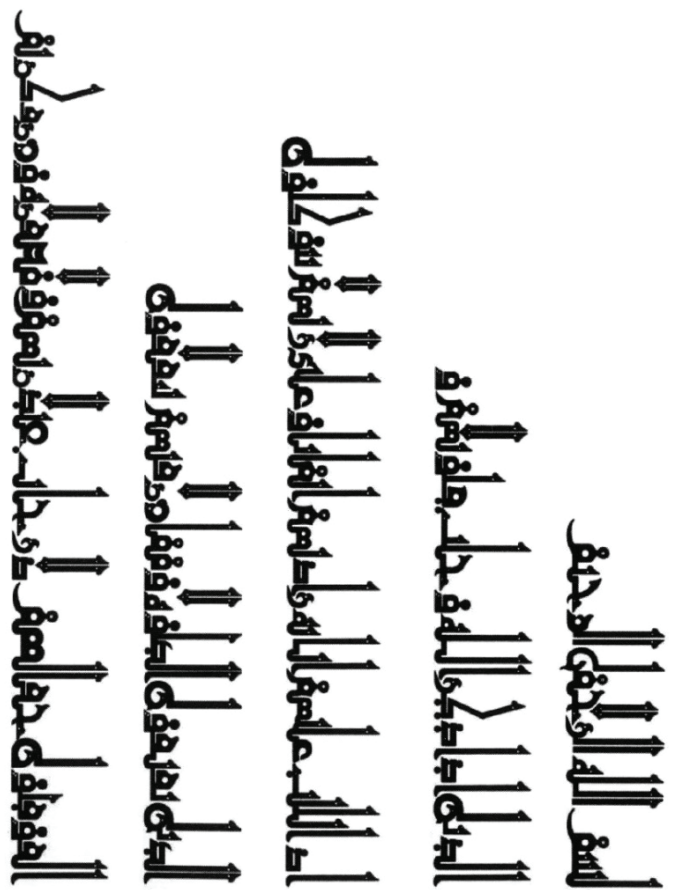

Çizim 18. Ardistân Cuma Camii Asıl Mihrabın Batısındaki IV. Kemerin Kitabe ve Süslemeleri (Azizpour'dan) 


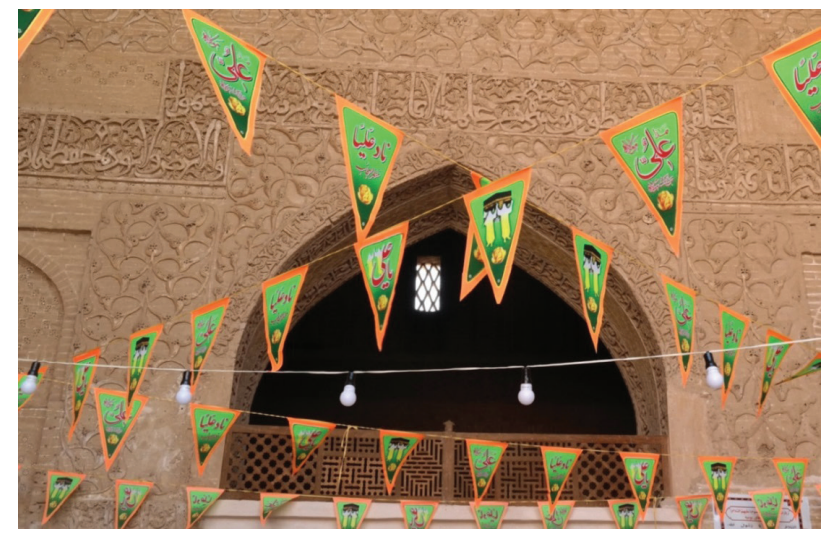

Resim 24. Ardistân Cuma Camii Güney Eyvanı Kitabe ve Süslemelerinden Ayrıntı
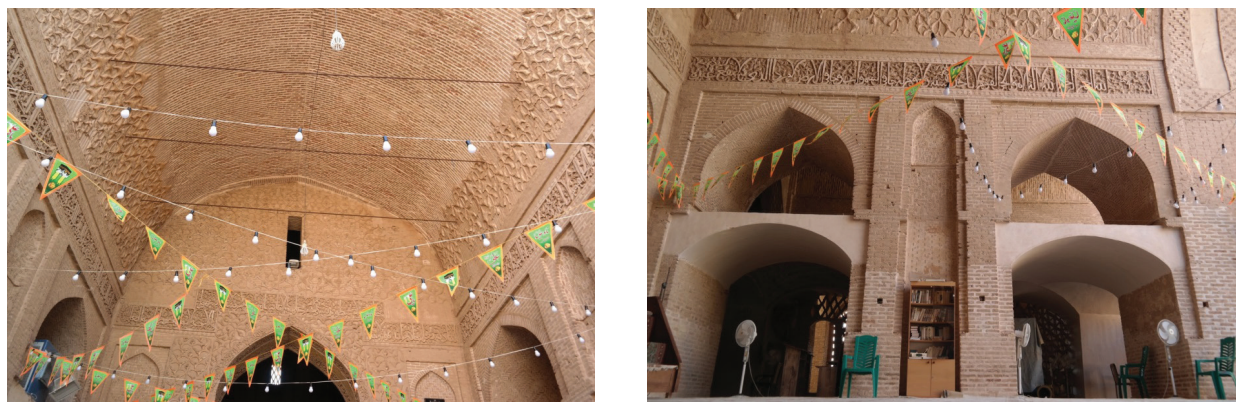

Resim 25. Ardistân Cuma Camii Güney Eyvanı Sülüs Kitabe Detayı

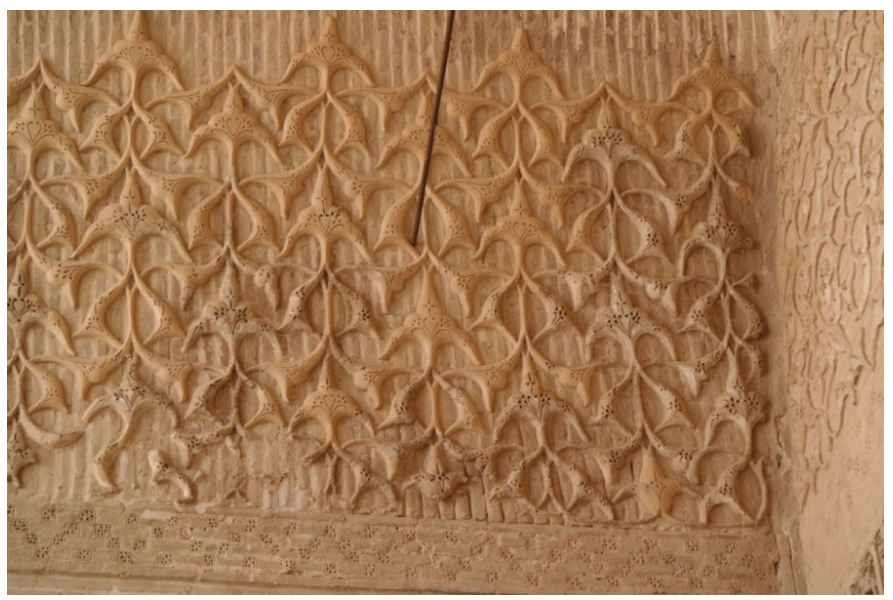

Resim 26. Ardistân Cuma Camii Güney Eyvanı Süslemeleri 

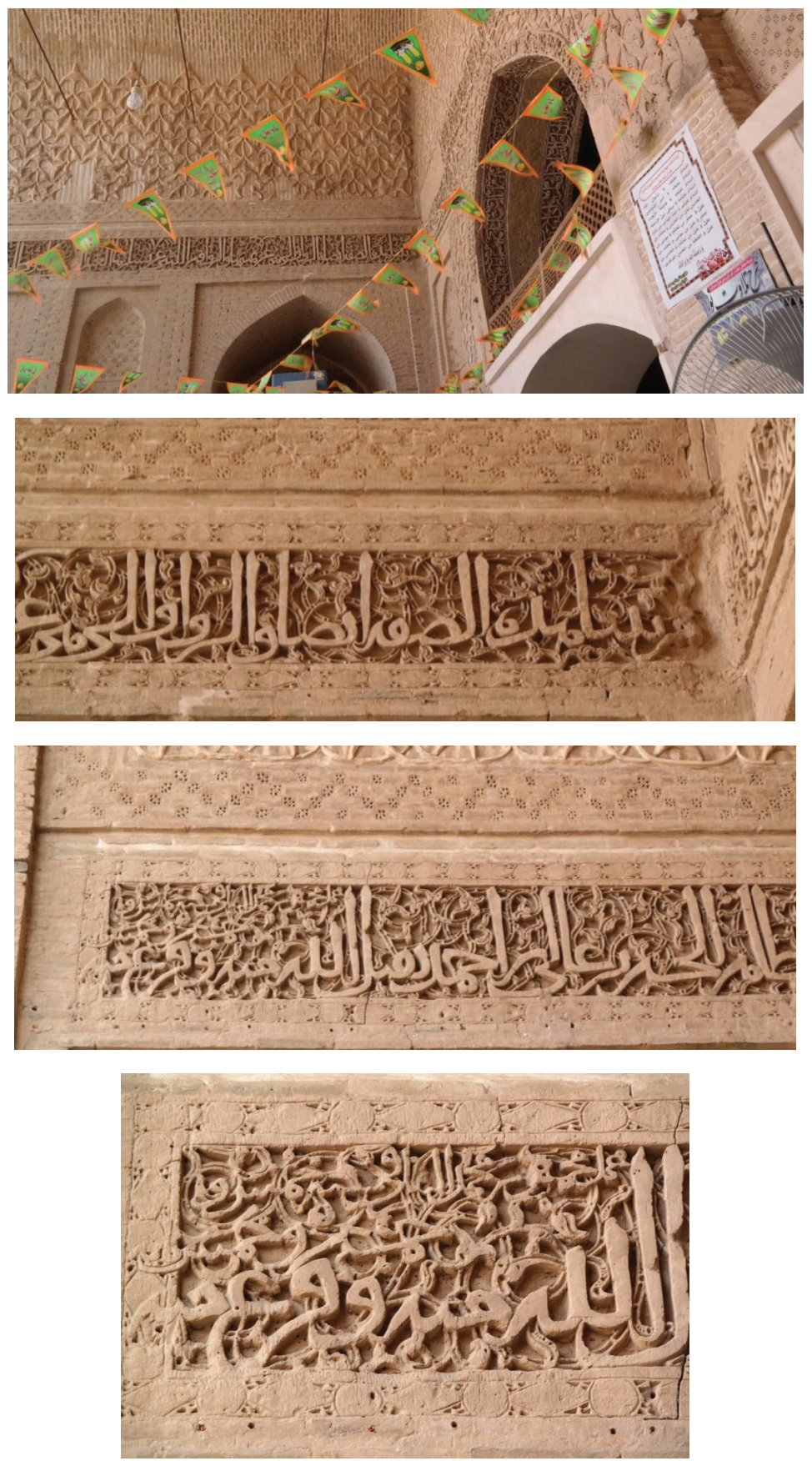

Resim 27. Ardistân Cuma Camii Güney Eyvanı Sülüs Kitabesi Detayı 

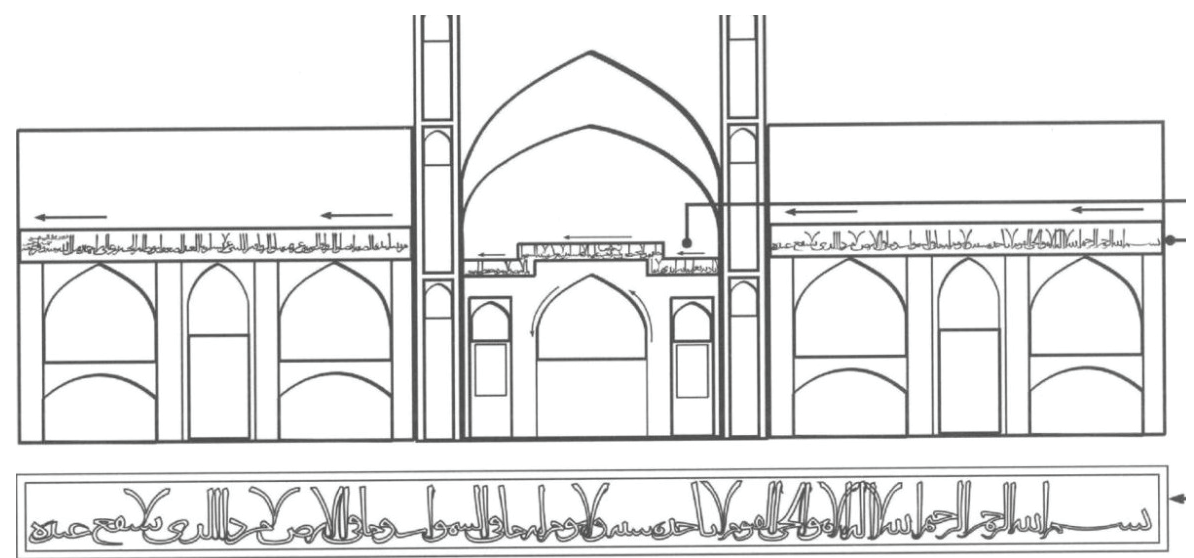

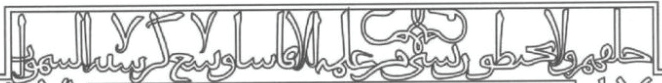

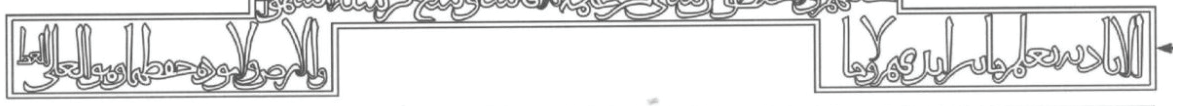

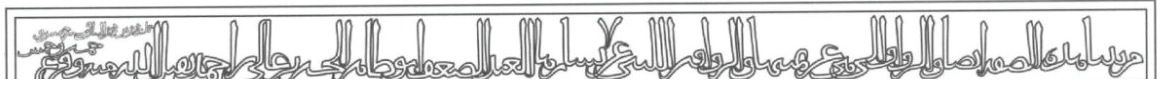

Çizim 19. Ardistân Cuma Camii Güney Eyvanındaki Kitabe (Azizpour'dan)
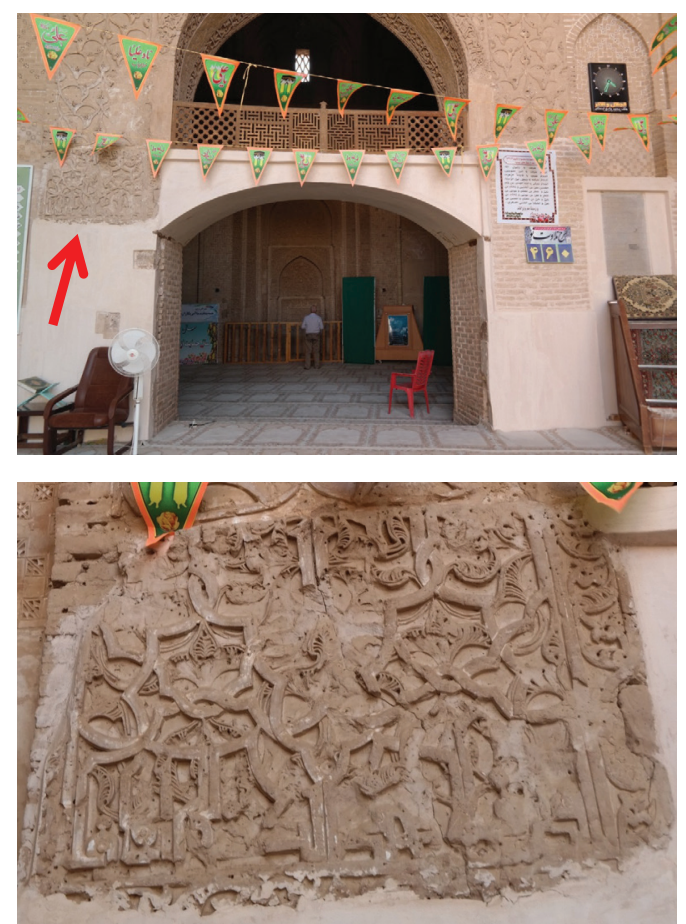

Resim 28. Ardistân Cuma Camii Güney Eyvanı Süslemeleri 


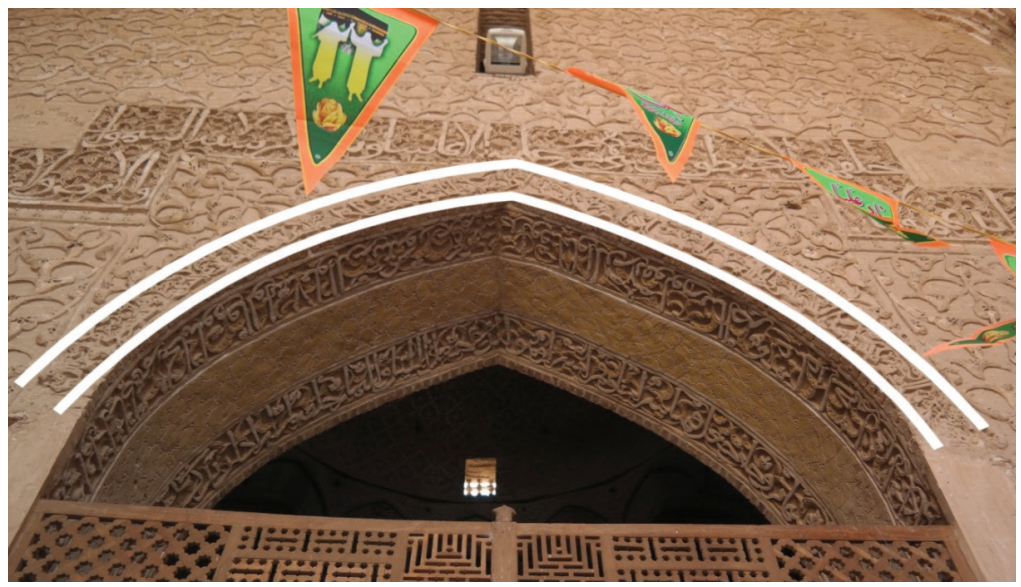

Resim 29. Ardistân Cuma Camii Güney Eyvanı Süslemeleri
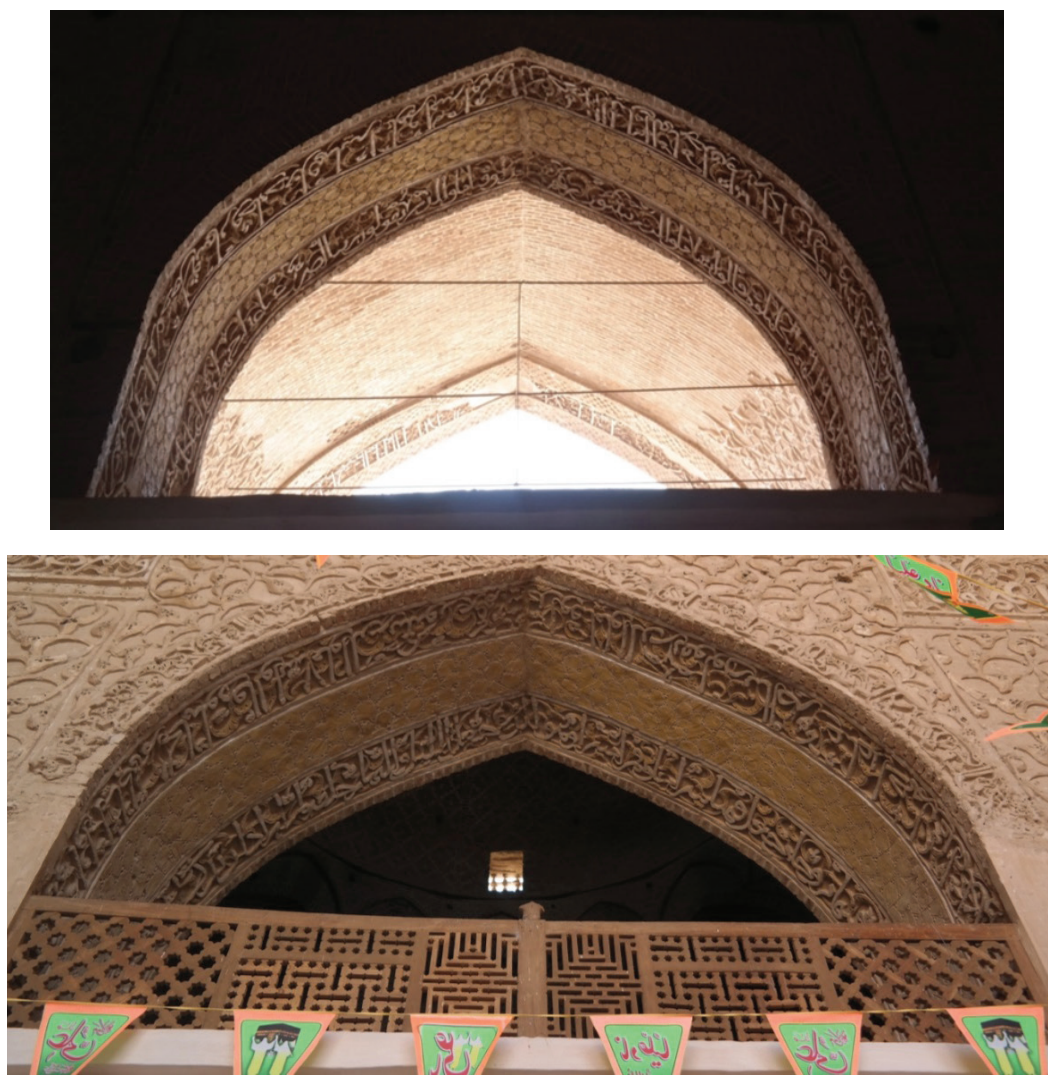

Resim 30. Ardistân Cuma Camii Güney Eyvanı Süslemeleri 


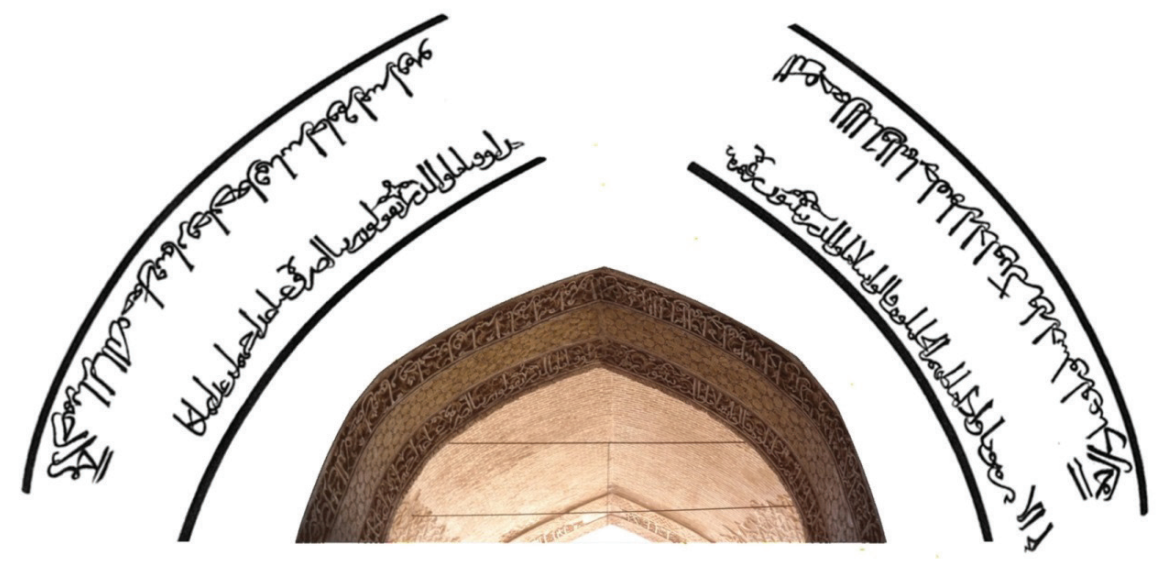

Çizim 20. Ardistân Cuma Camii

Güney Eyvanında Bulunan Kitabe (Azizpour'dan)

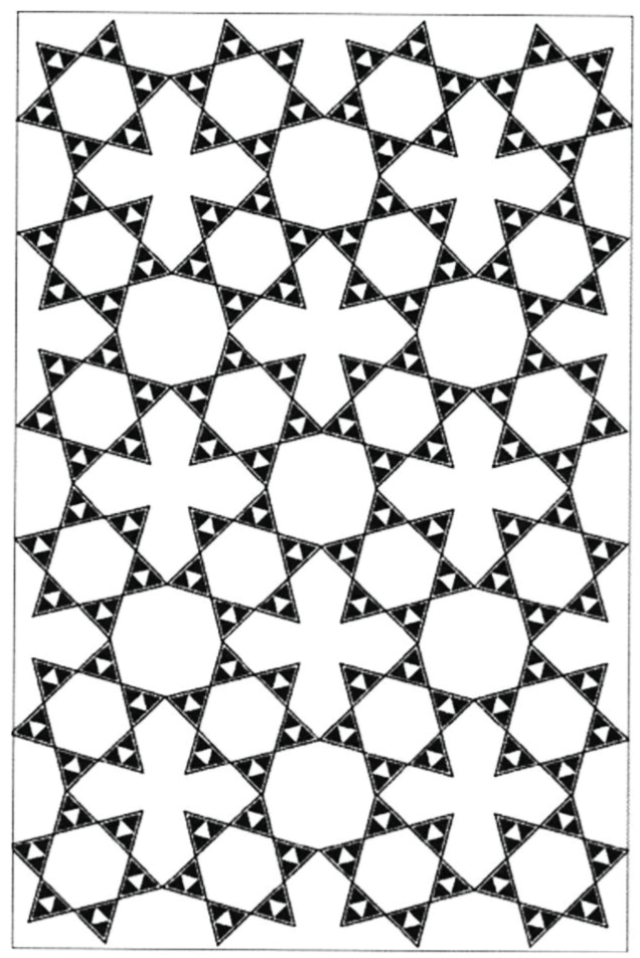

Çizim 21. Ardistân Cuma Camii Güney

Eyvanında Bulunan Süslemeler (Azizpour'dan) 


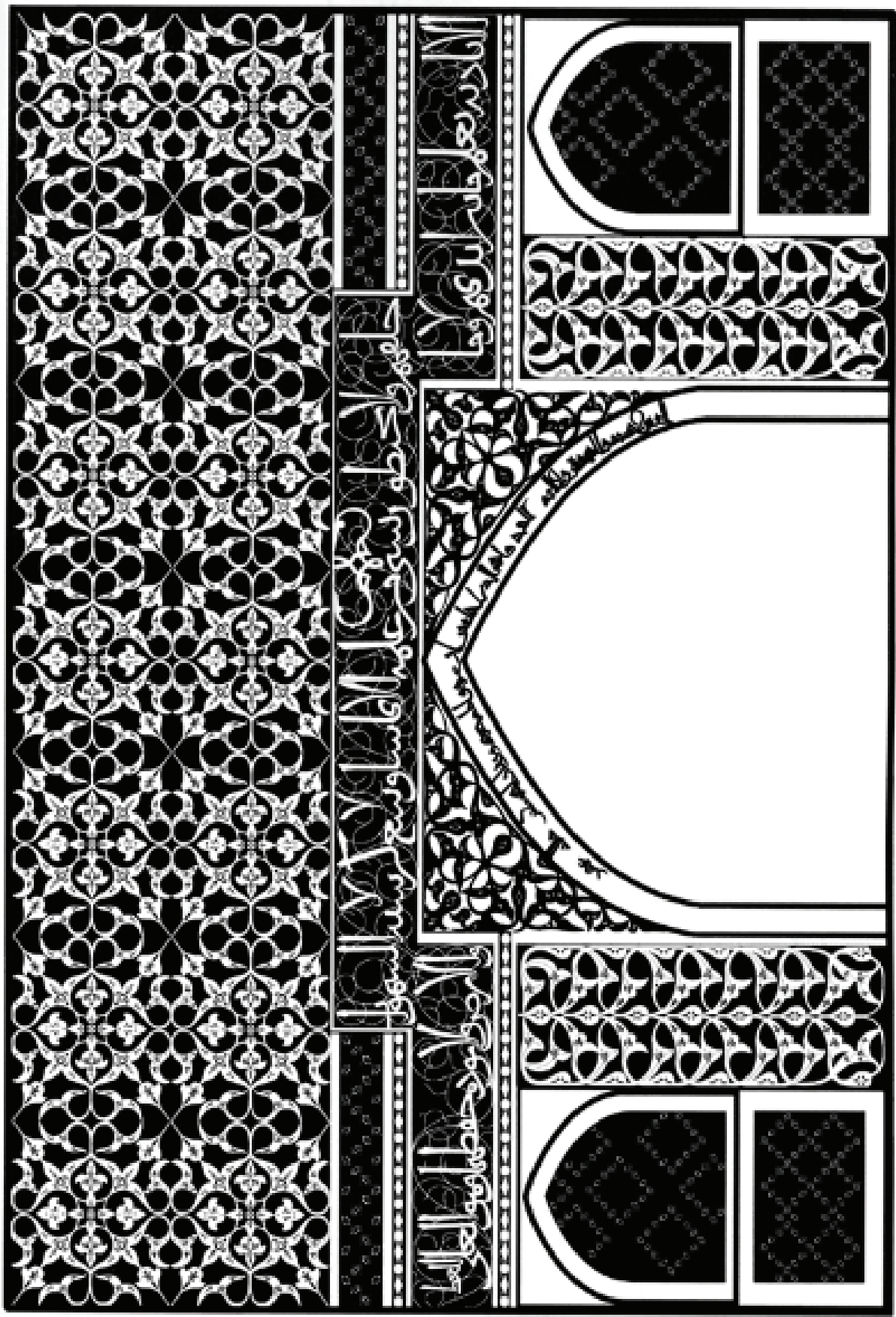

Çizim 22. Ardistân Cuma Camii Güney Eyvanındaki Kitabe ve Süslemeler (Azizpour'dan) 


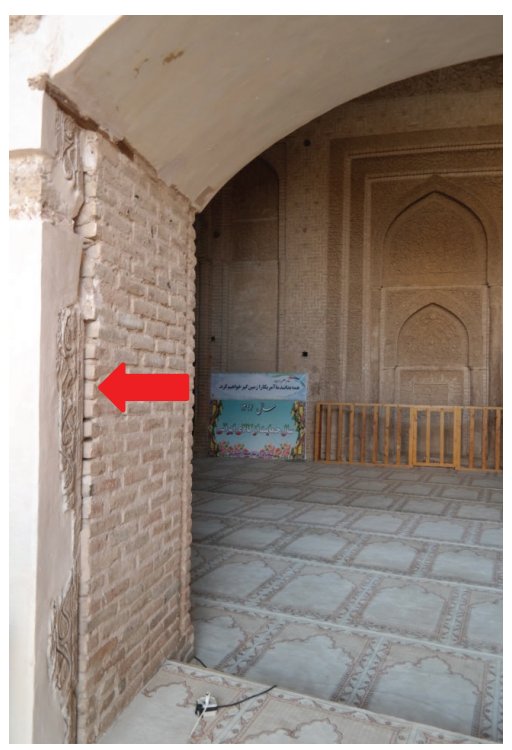

Resim 31. Ardistân Cuma Camii Güney Eyvanı Süslemeleri

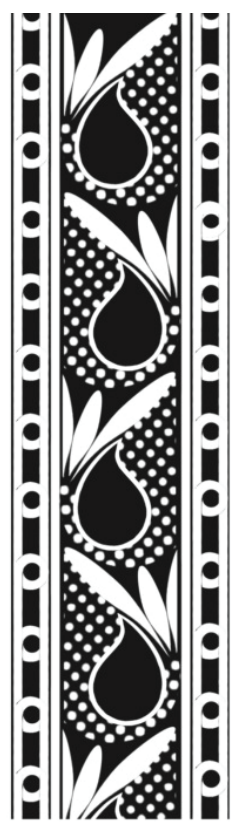

Çizim 23. Ardistân Cuma Camii Güney Eyvanında Bulunan Süslemeler

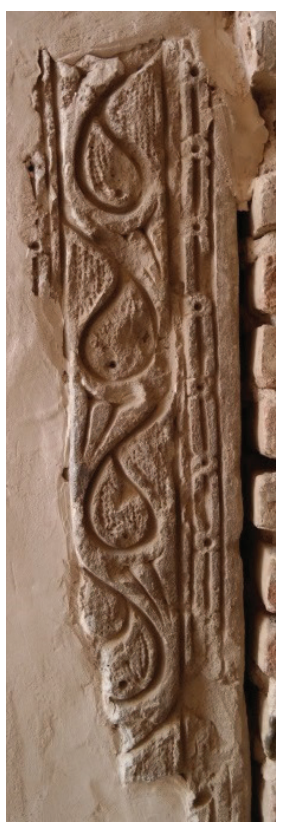

Resim 32. Ardistân Cuma Camii Güney Eyvanı Süslemeleri 


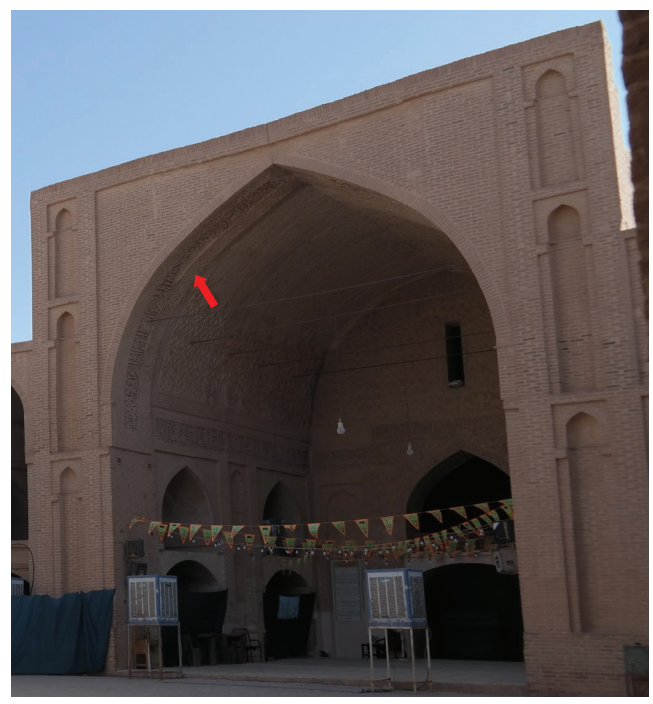

Resim 33. Ardistân Cuma Camii Güney Eyvanı Kitabe ve Süslemeleri

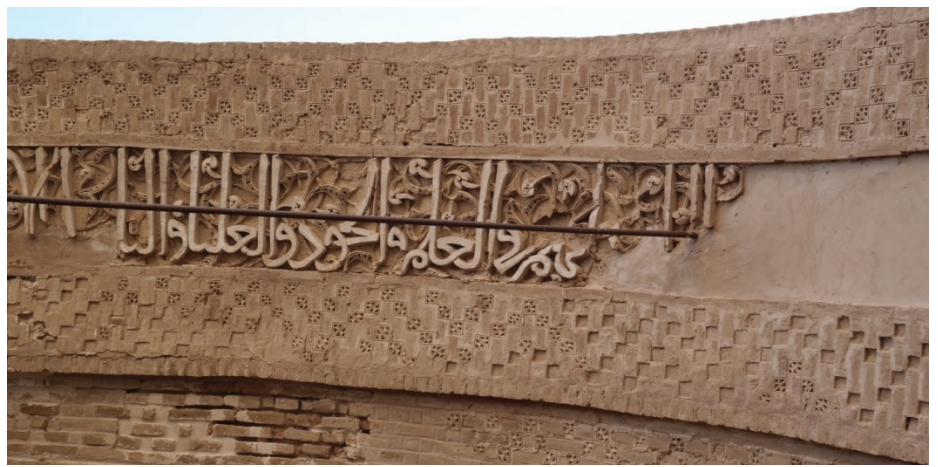

Resim 34. Ardistân Cuma Camii Güney Eyvanı Kitabe ve Süslemeleri

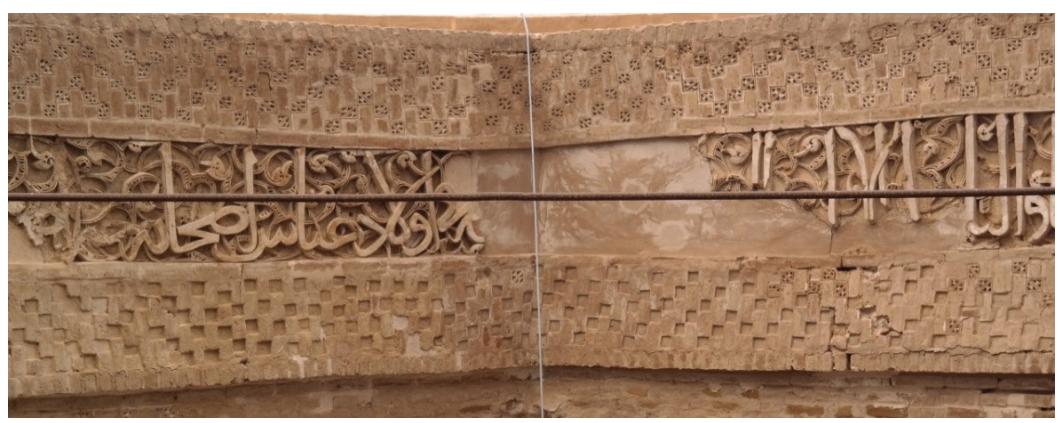

Resim 35. Ardistân Cuma Camii Güney Eyvanı Kitabe ve Süslemeleri 


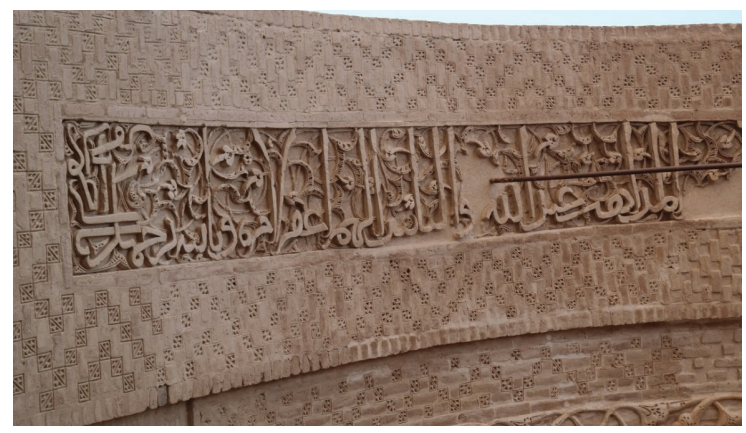

Resim 36. Ardistân Cuma Camii Güney Eyvanı Kitabe ve Süslemeleri

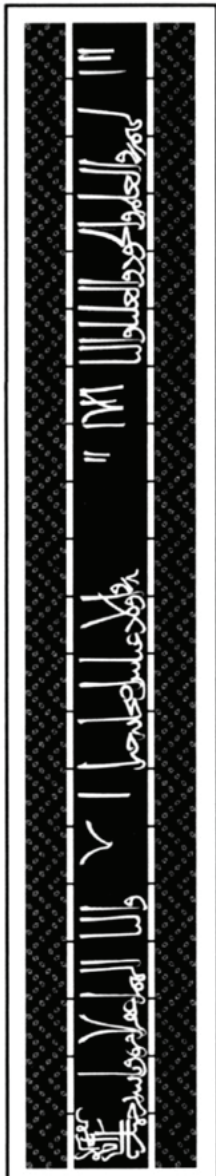

Çizim 24. Ardistân Cuma Camii Güney Eyvanında Bulunan Kitabe ve Süslemeler (Azizpour'dan) 


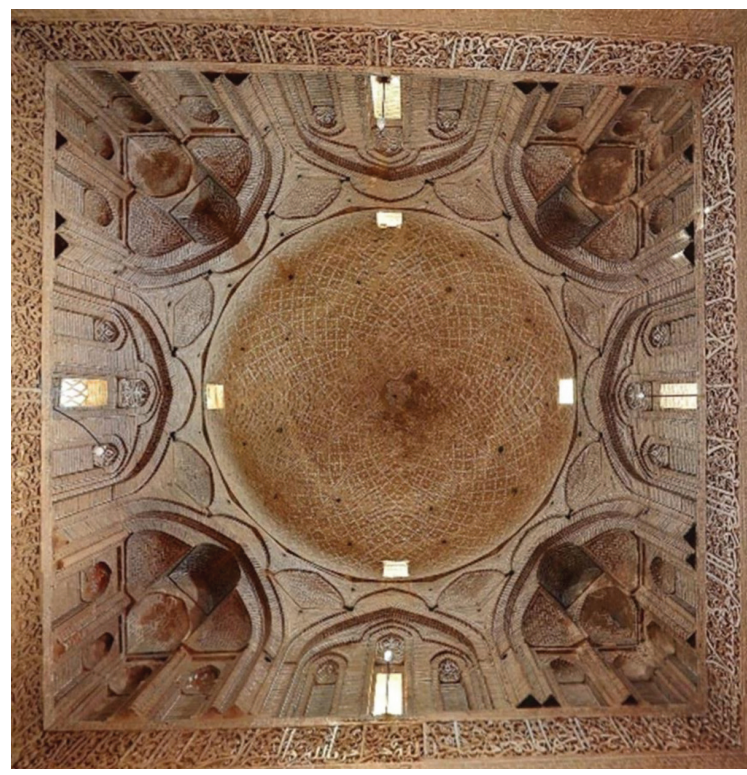

Resim 37. Ardistân Cuma Camii Yazı Kuşağı
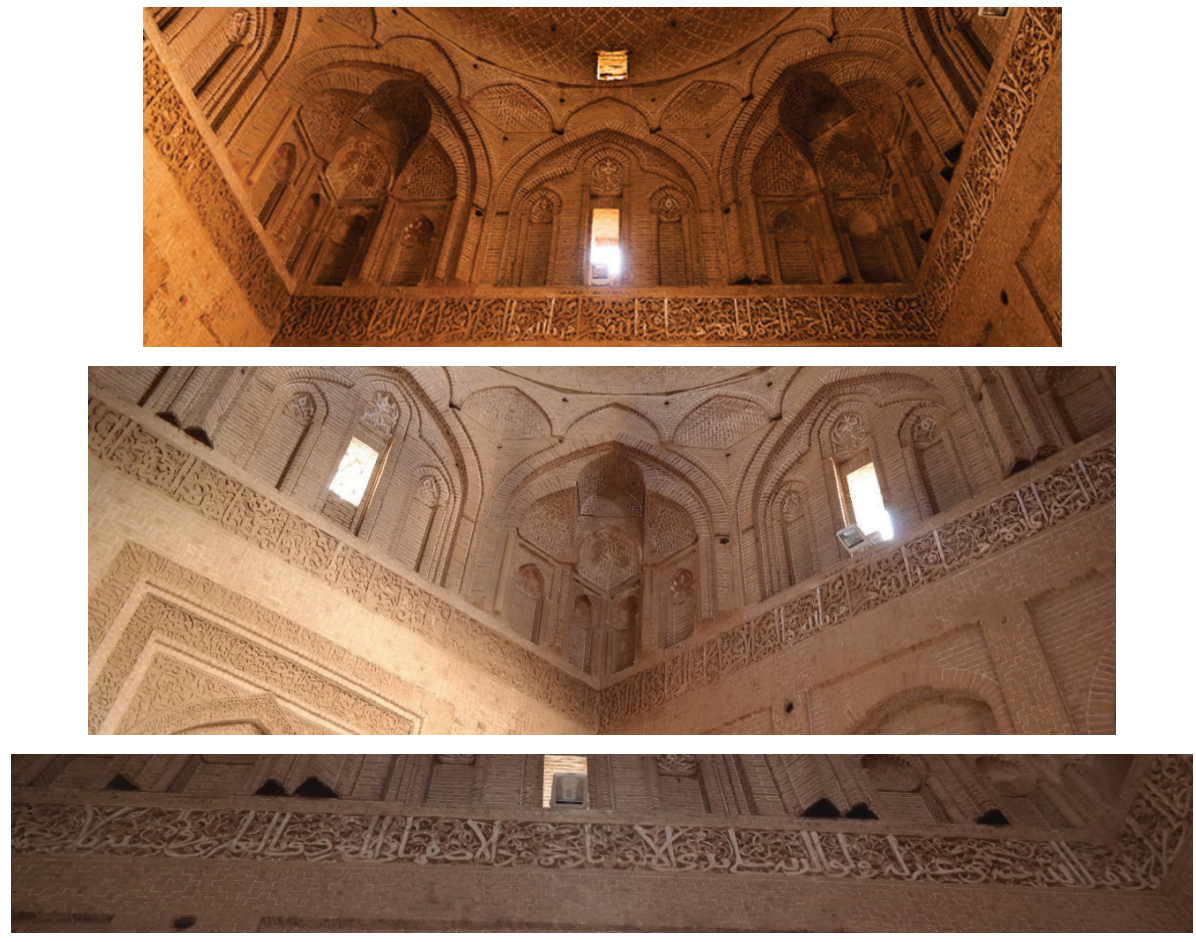

Resim 38. Ardistân Cuma Camii Yazı Kuşağından Ayrıntılar 

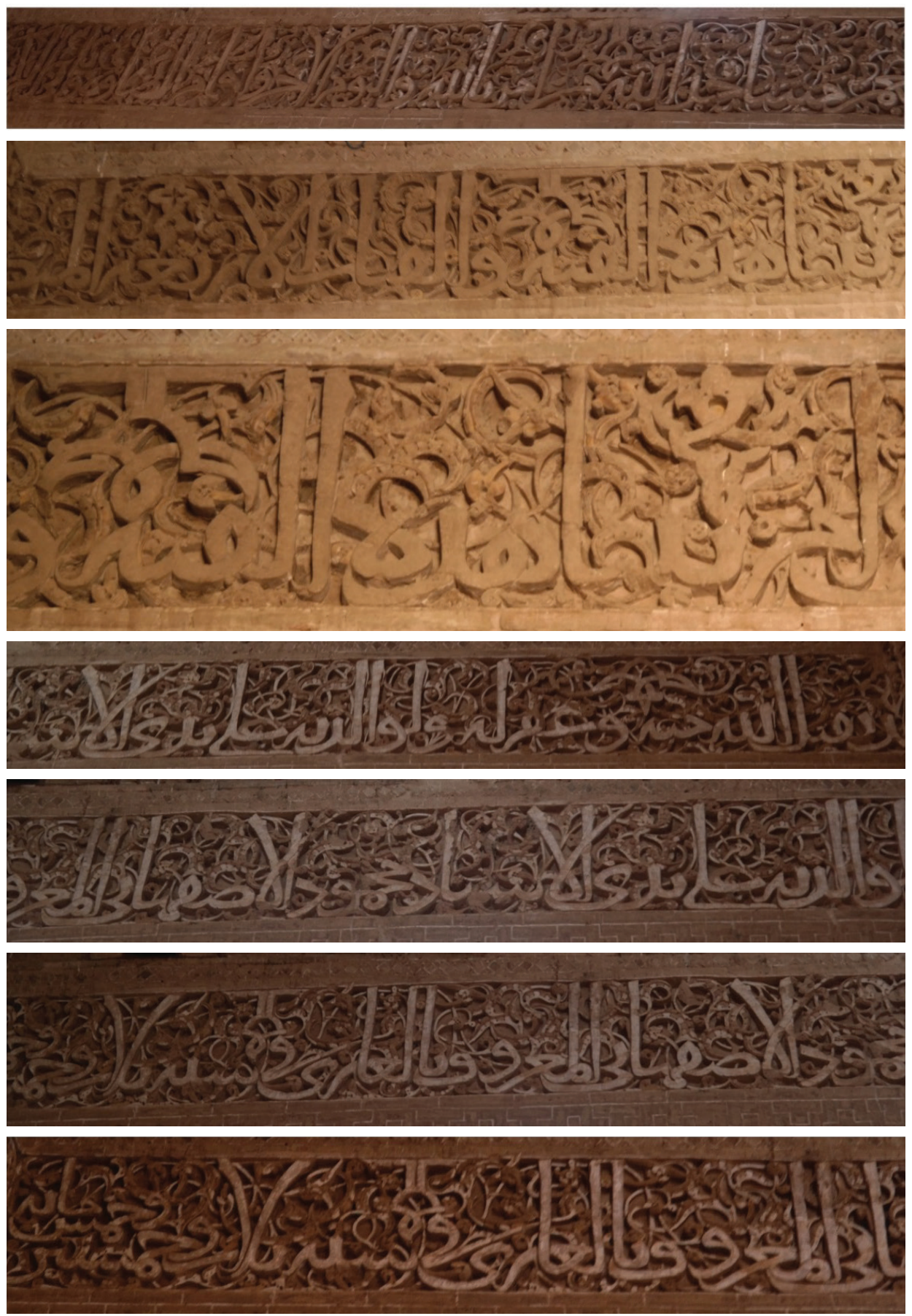

Resim 39. Ardistân Cuma Camii Yazı Kuşağından Ayrıntılar 

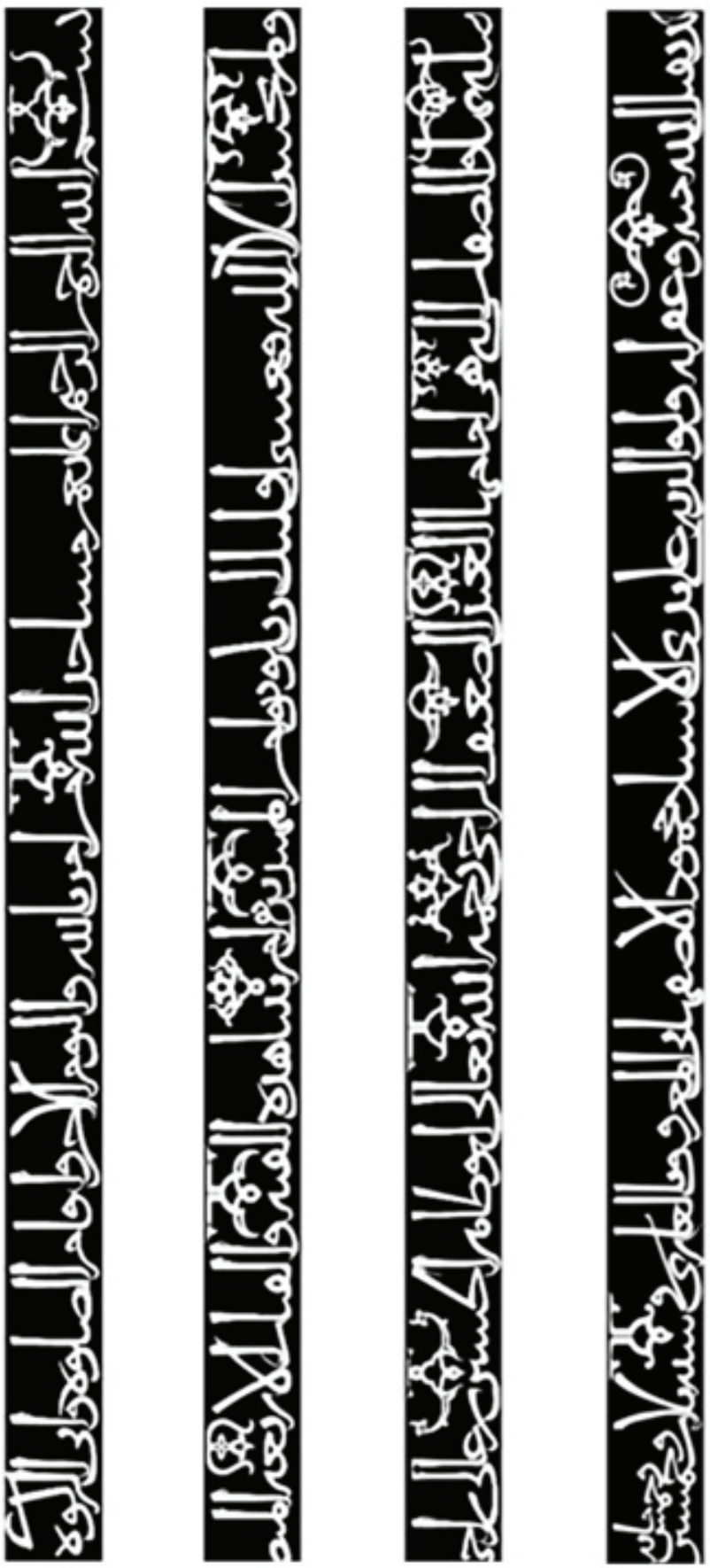

Çizim 25. Ardistân Cuma Camii Yazı Kuşağı (Azizpour'dan) 


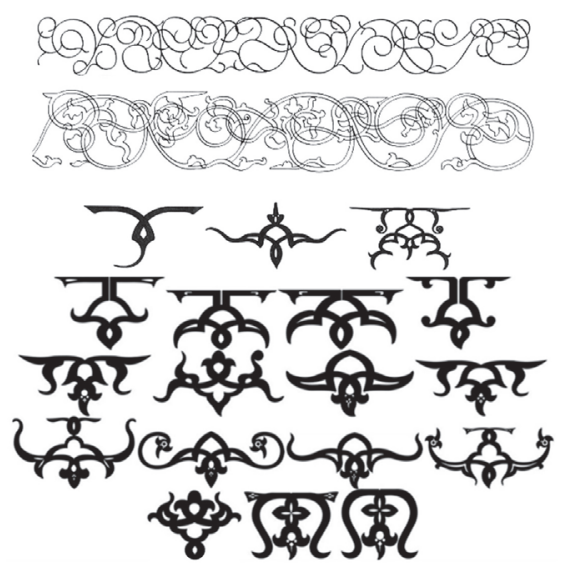

Çizim 26. Ardistân Cuma Camii Yazı Kuşağı (Azizpour’dan)

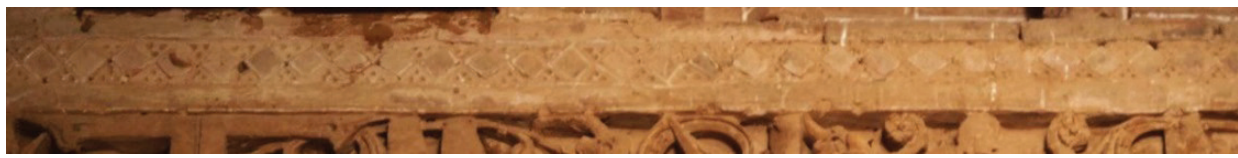

Resim 40. Ardistân Cuma Camii Yazı Kuşağını Kuşatan Süsleme Şeridi

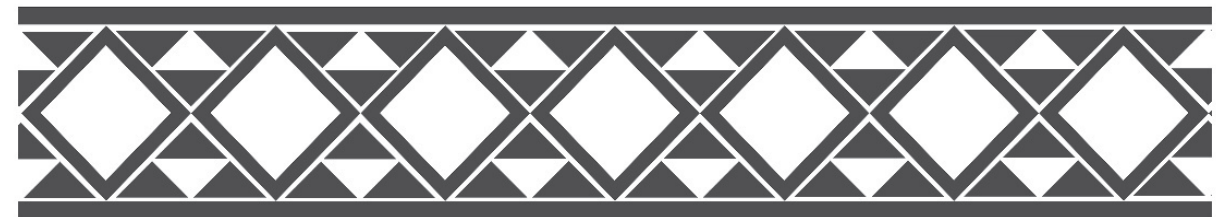

Çizim 27. Ardistân Cuma Camii Yazı Kuşağını Kuşatan Süsleme Şeridi

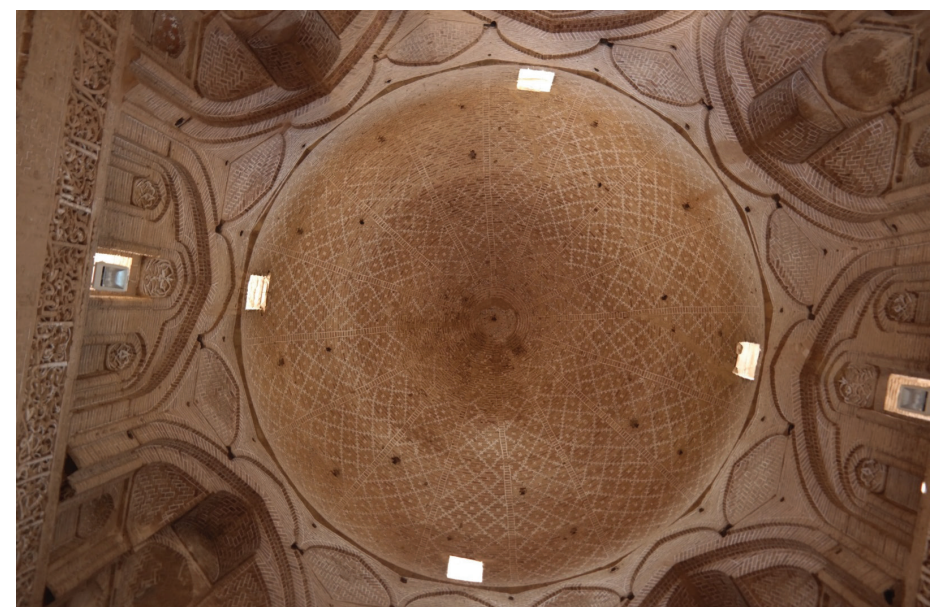

Resim 41. Ardistân Cuma Camii Trompları ve Ara Yüzeylerdeki Nişler 


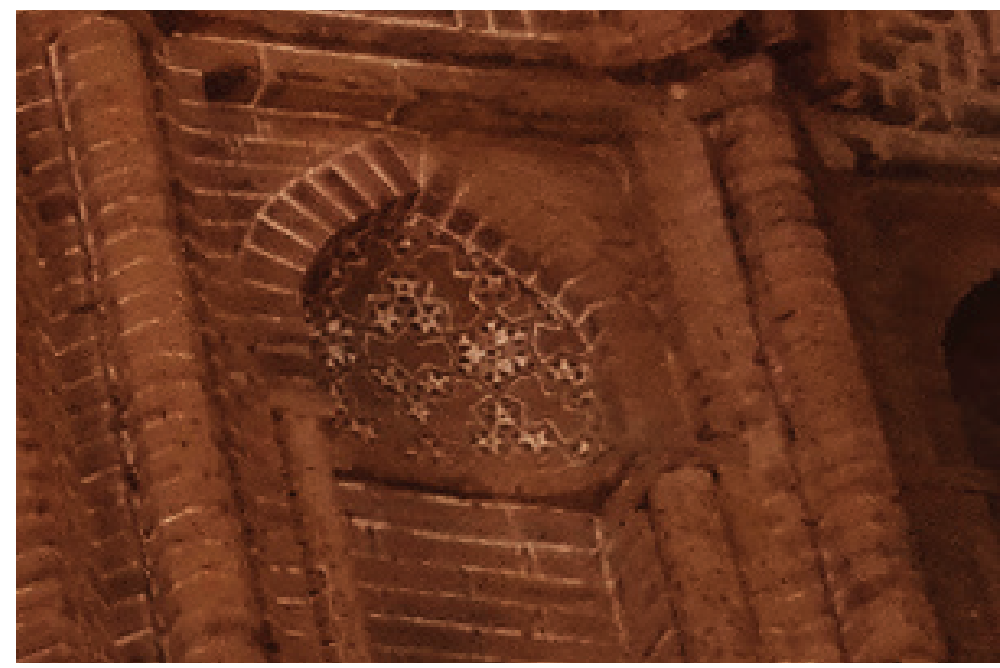

Resim 42. Ardistân Cuma Camii Trompları ve Ara Yüzeylerdeki Nişlerin Süslemeleri

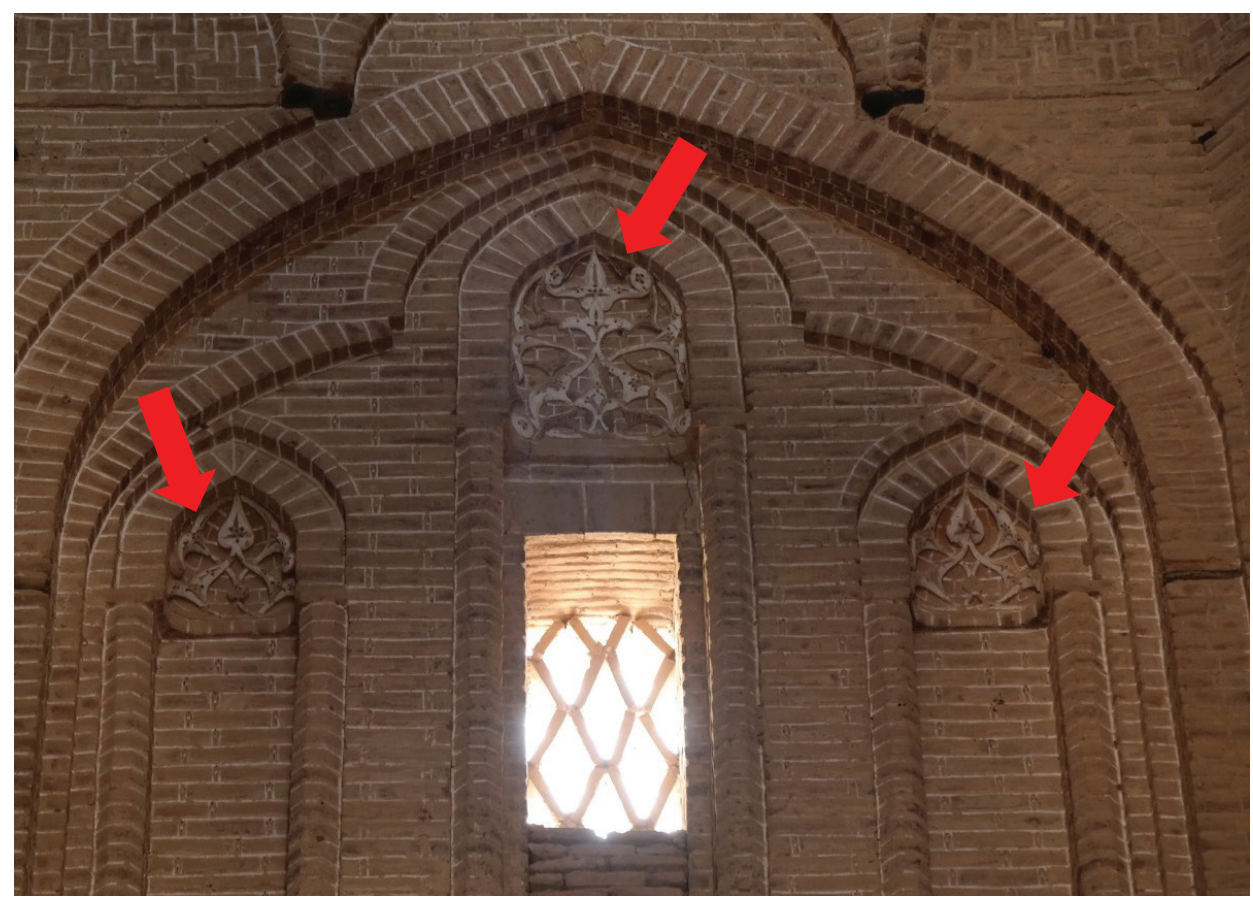

Resim 43. Ardistân Cuma Camii Trompları ve Ara Yüzeylerdeki Nişlerin Süslemeleri 

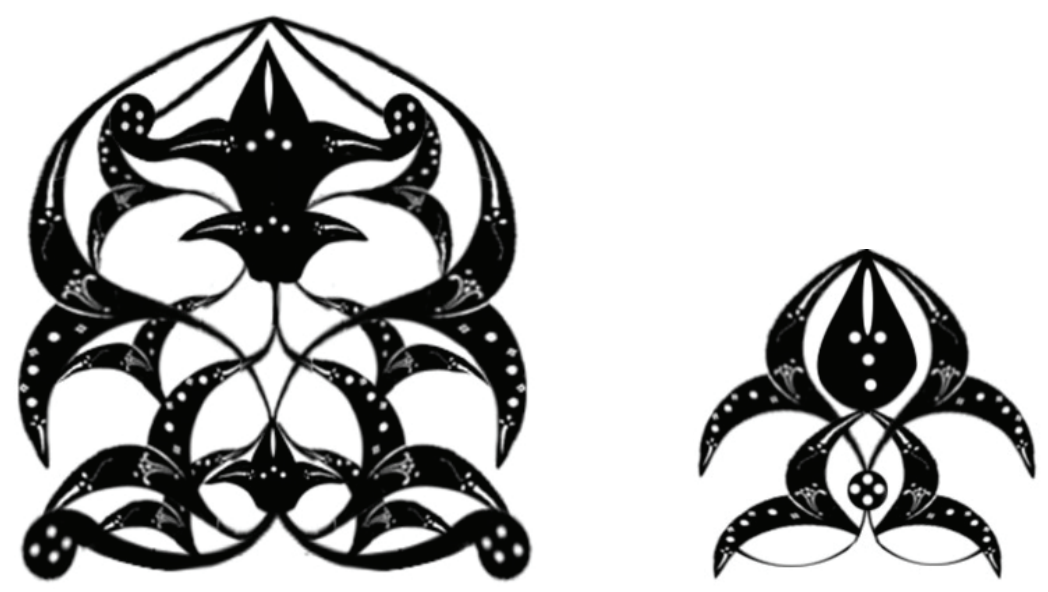

Çizim 28. Ardistân Cuma Camii Tromplar ve Ara Yüzlerdeki Nişler

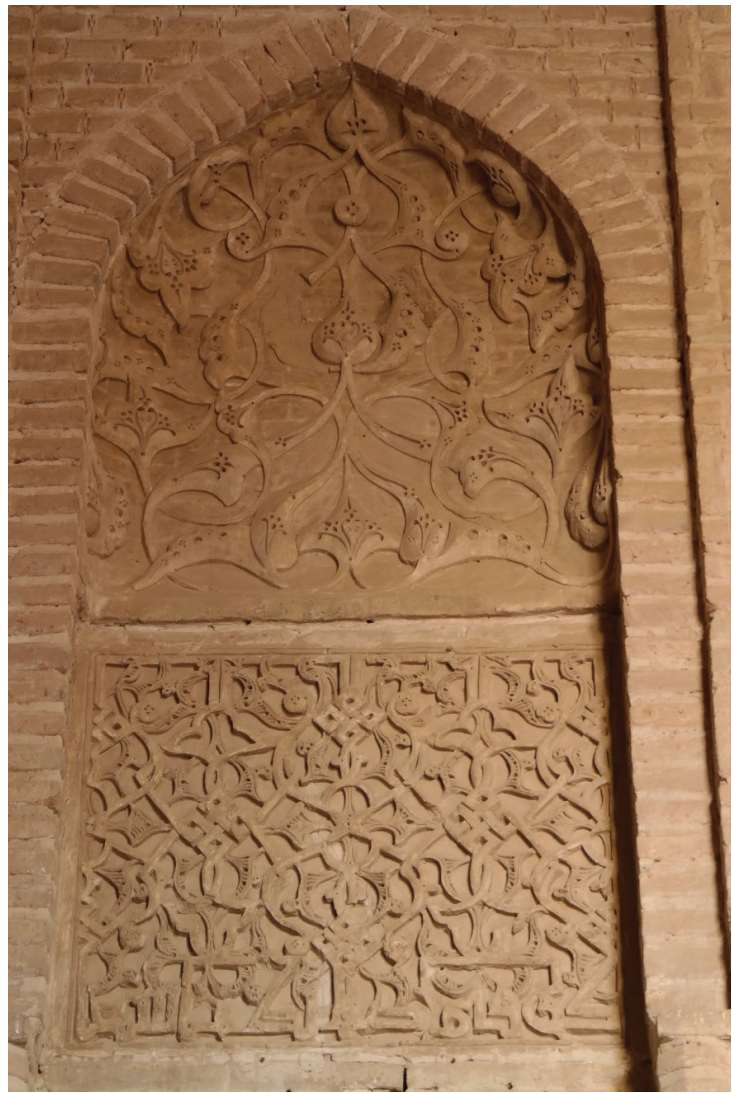

Resim 44. Ardistân Cuma Camii Asıl Mihrabı Doğusundaki I. Niş 

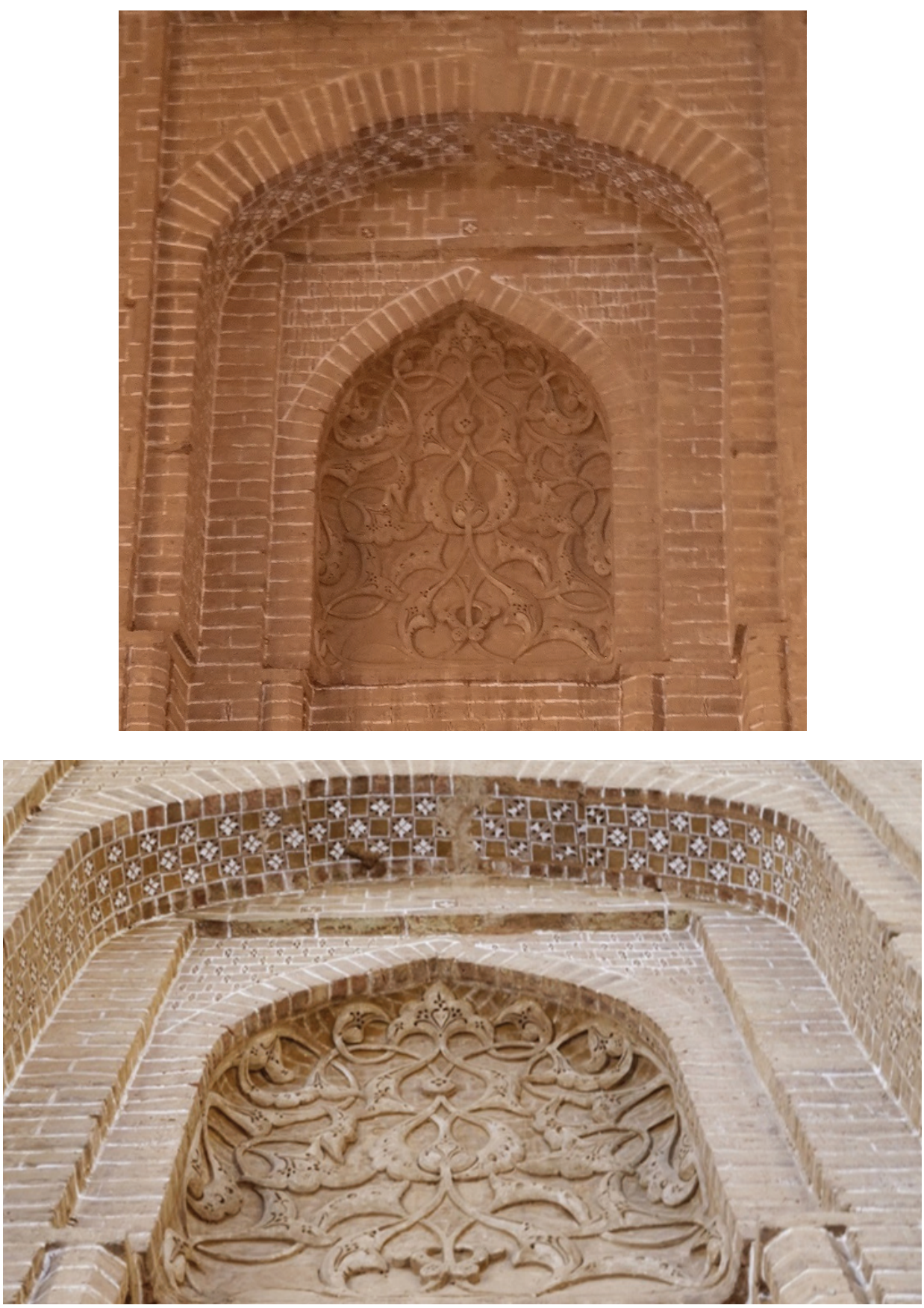

Resim 45. Ardistân Cuma Camii Kubbeli Mekândaki II. Niş 


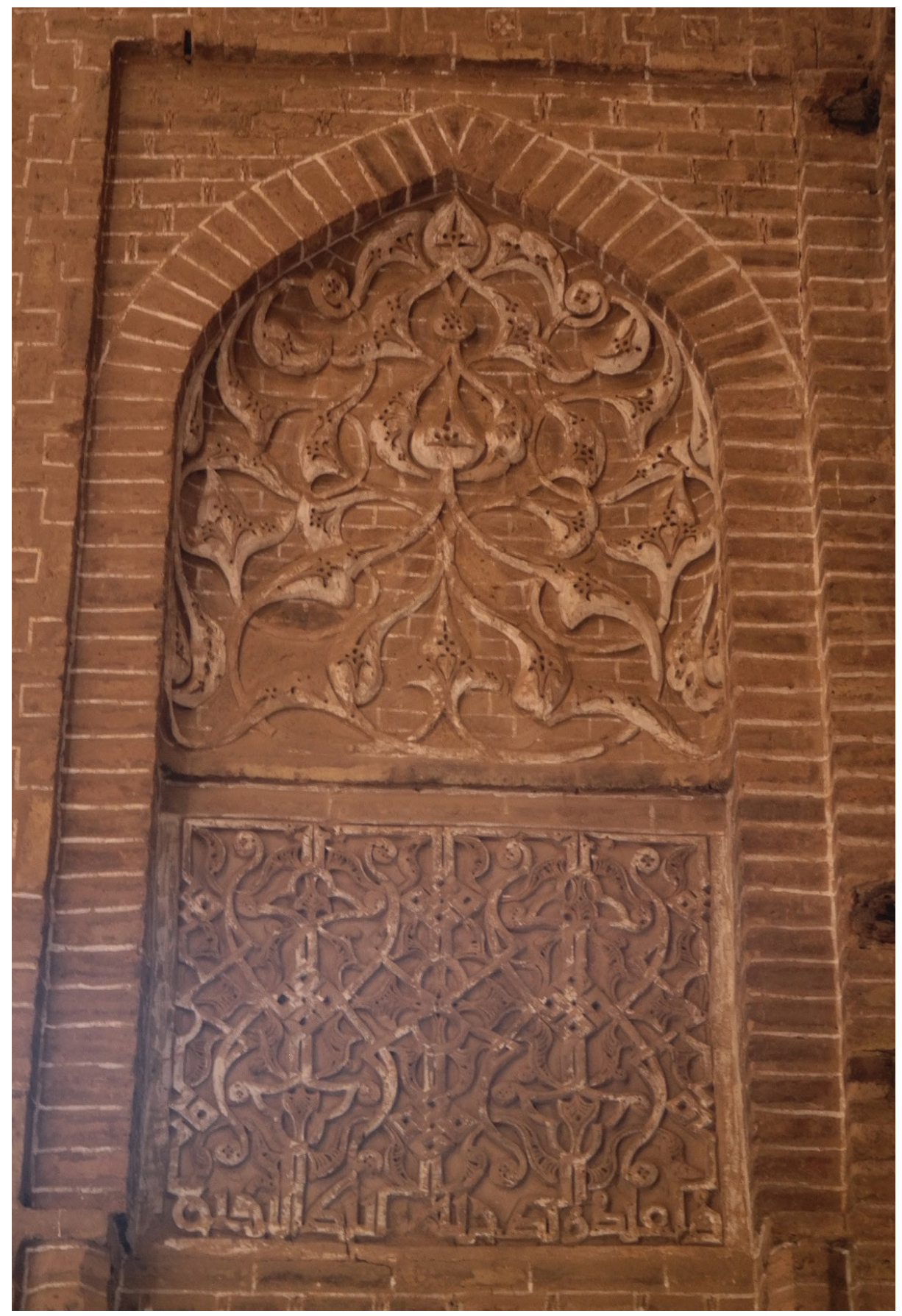

Resim 46. Ardistân Cuma Camii Kubbeli Mekândaki III. Niş 

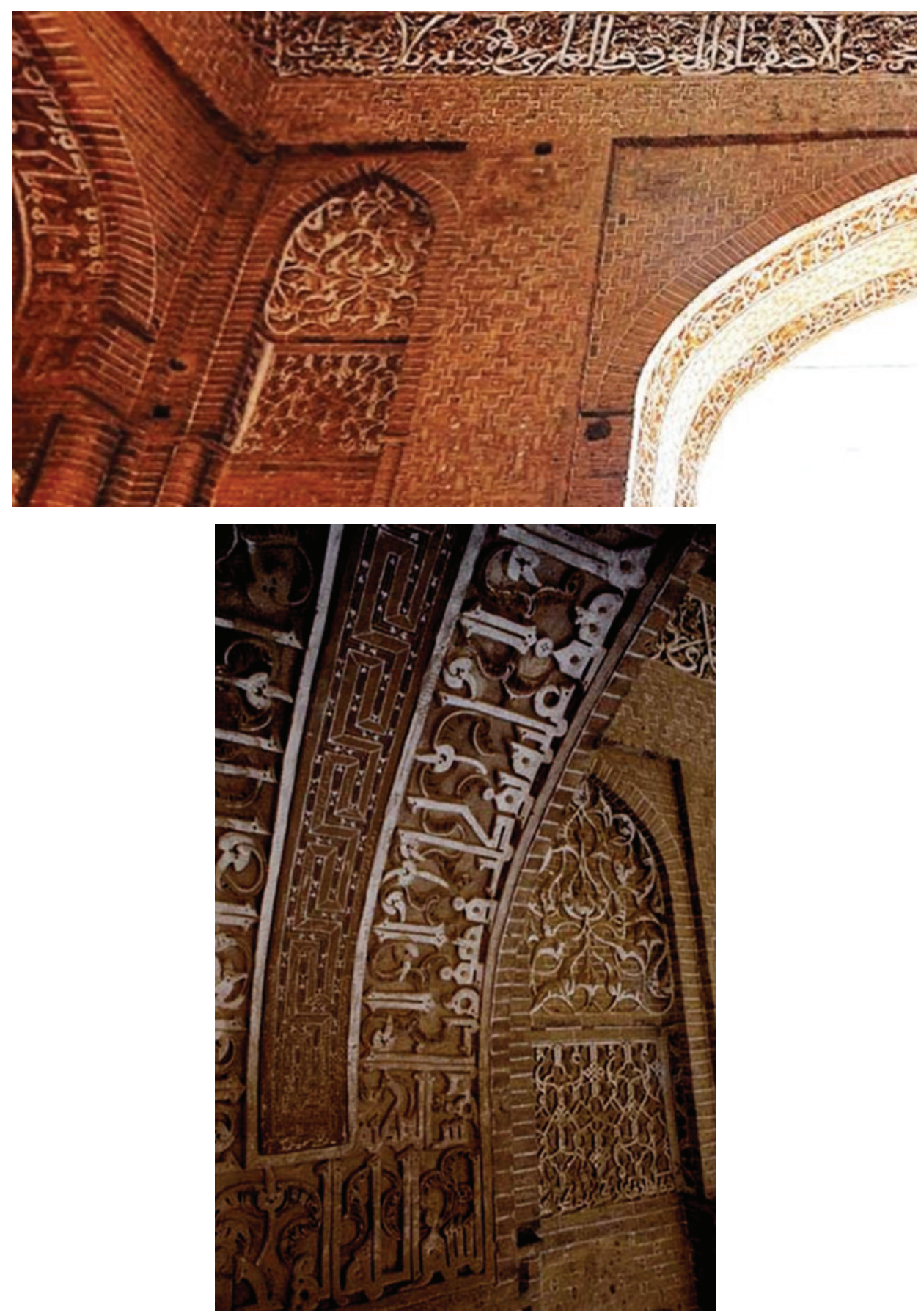

Resim 47. Ardistân Cuma Camii Kubbeli Mekândaki IV. Niş 


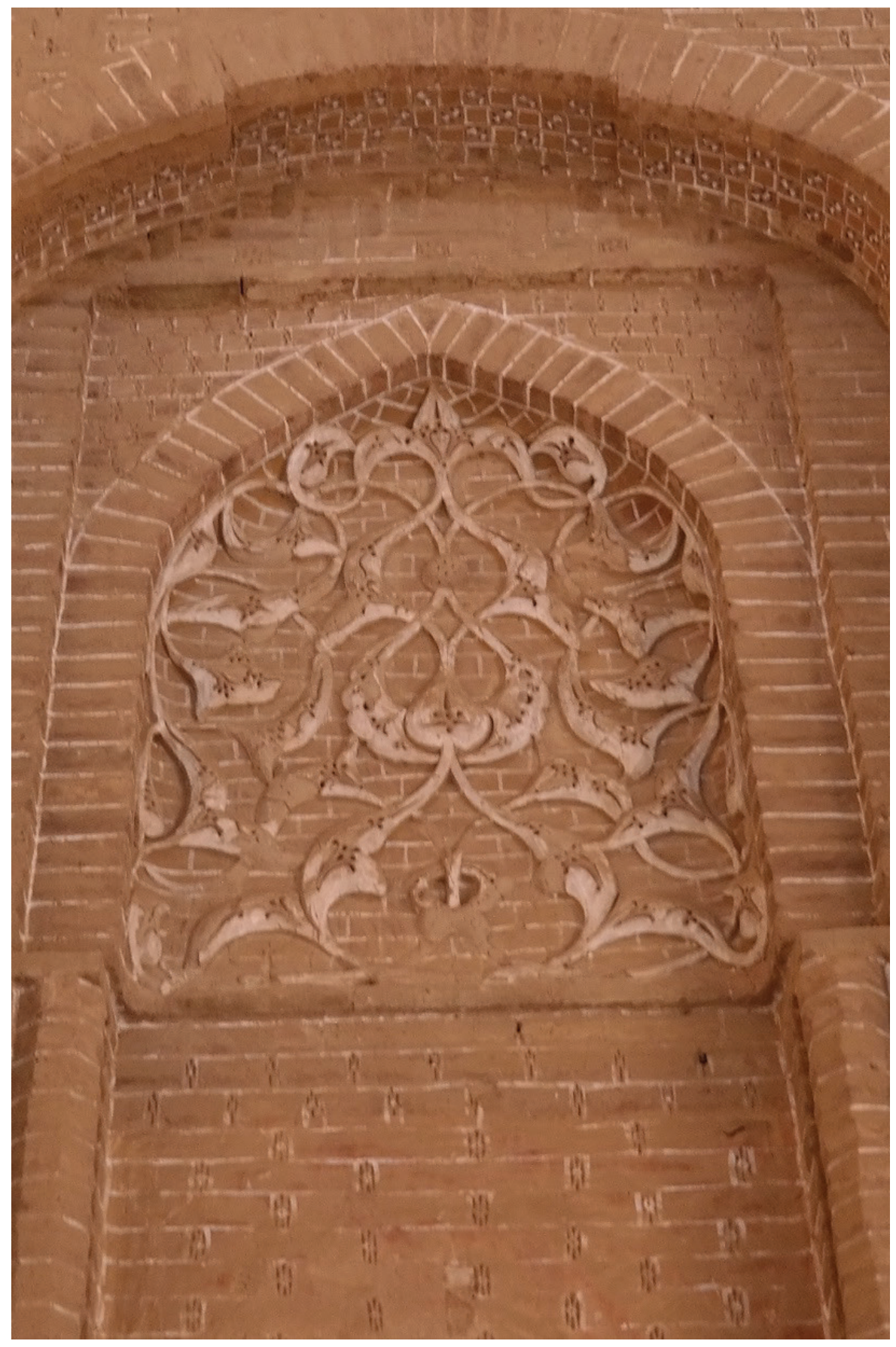

Resim 48. Ardistân Cuma Camii Kubbeli Mekândaki V. Niş 


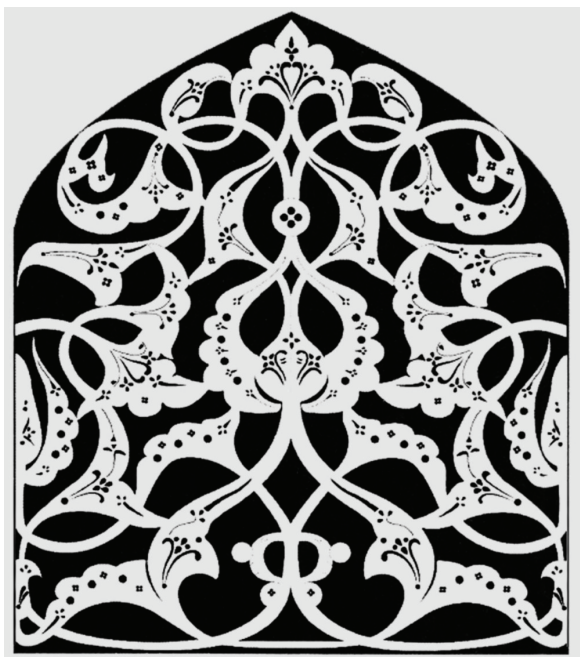

Çizim 29. Ardistân Cuma Camii V. Nişin Süslemeleri (Azizpour'dan)

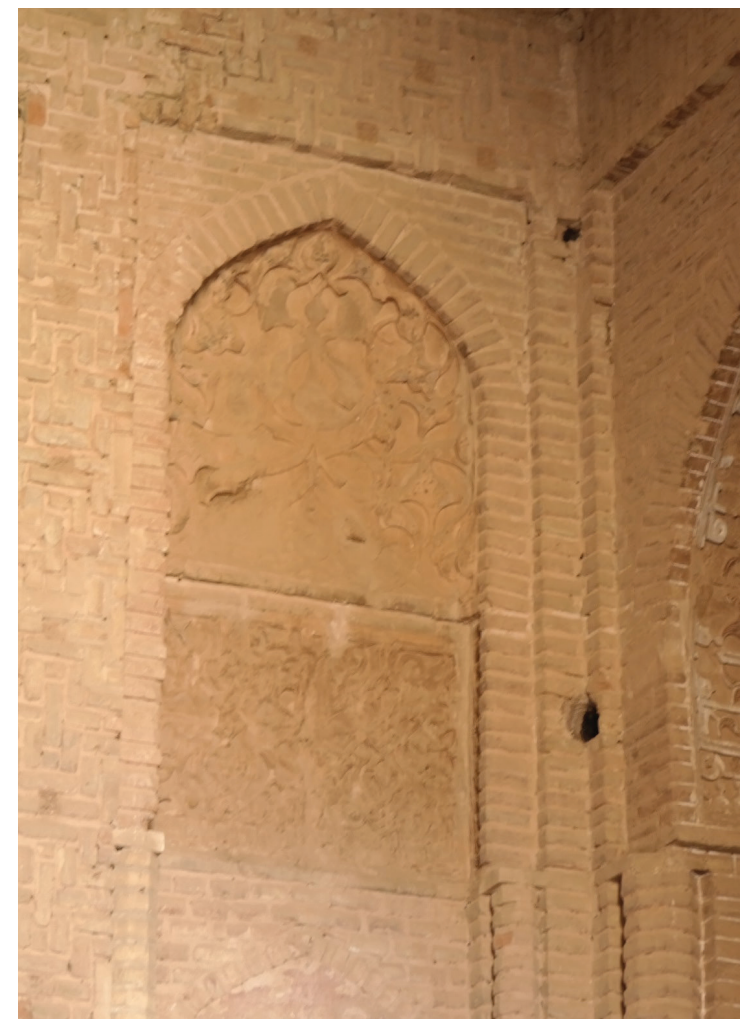

Resim 49. Ardistân Cuma Camii Asıl Mihrabın Batısındaki VI. Niş 

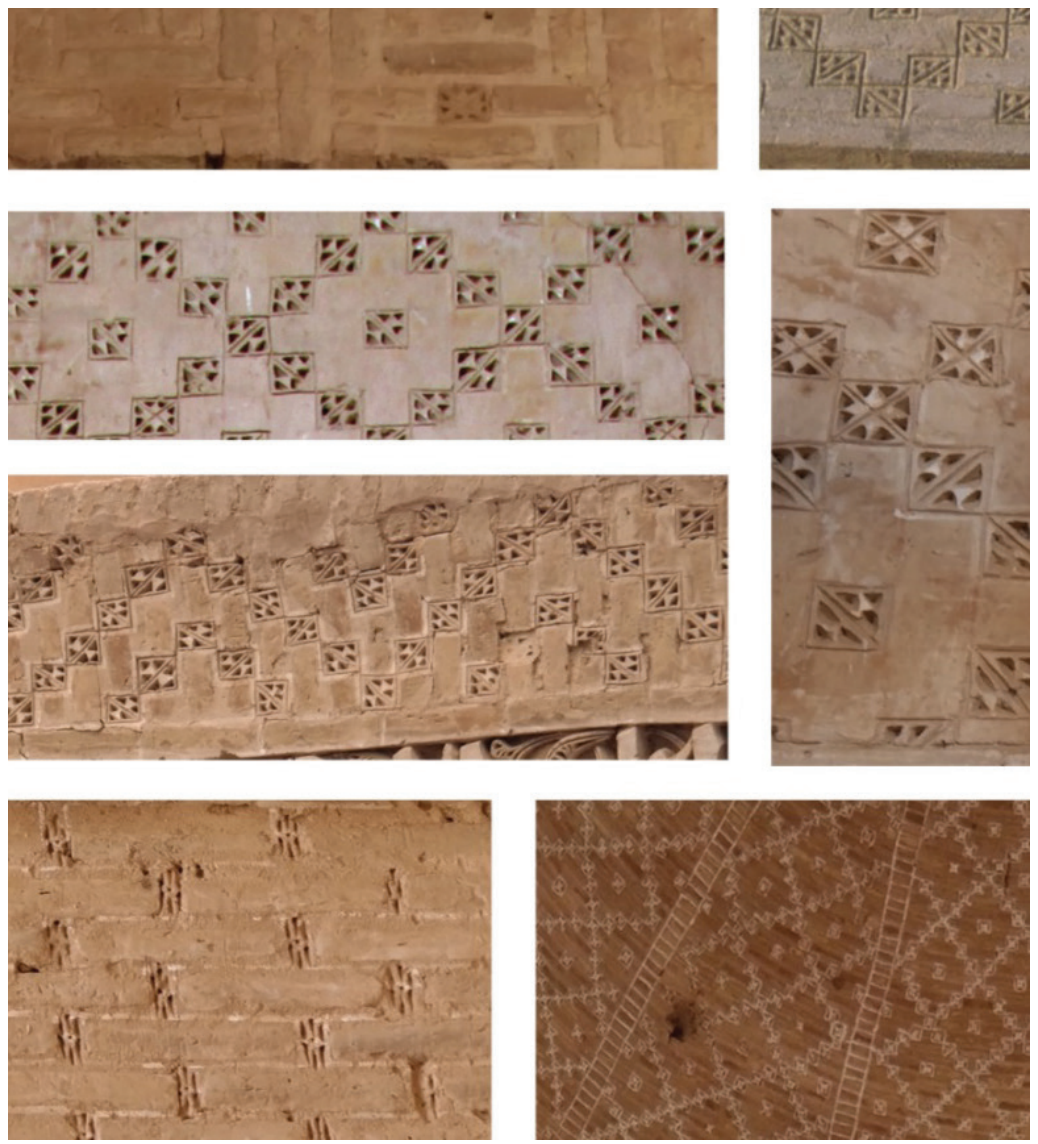

Resim 50. Ardistân Cuma Camii Alçı Derz Süslemeleri

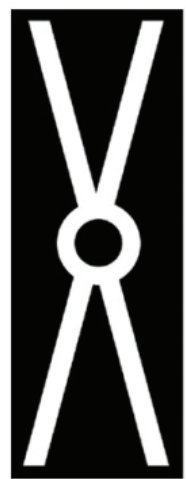

Çizim 30. Ardistân Cuma Camii Alçı Derz Süslemeleri (Azizpour'dan) 


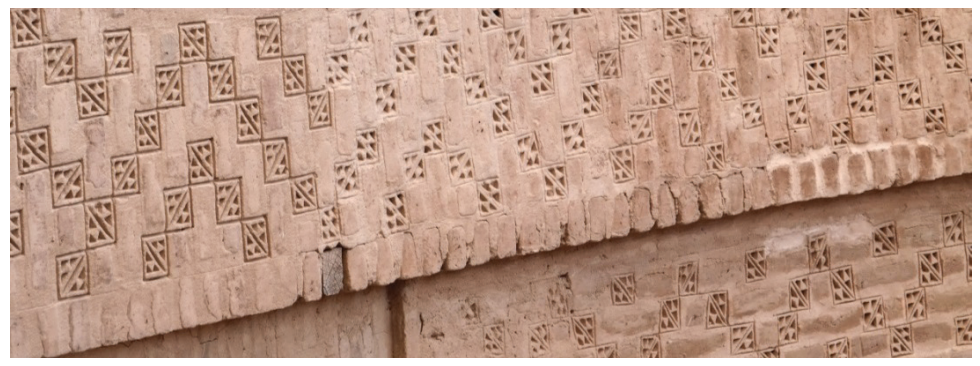

Resim 51. Ardistân Cuma Camii Alçı Derz Süslemeleri

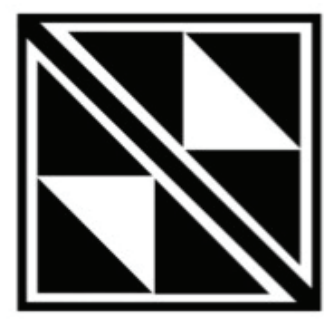

Çizim 31. Ardistân Cuma Camii Alçı Derz Süslemeleri (Azizpour'dan)

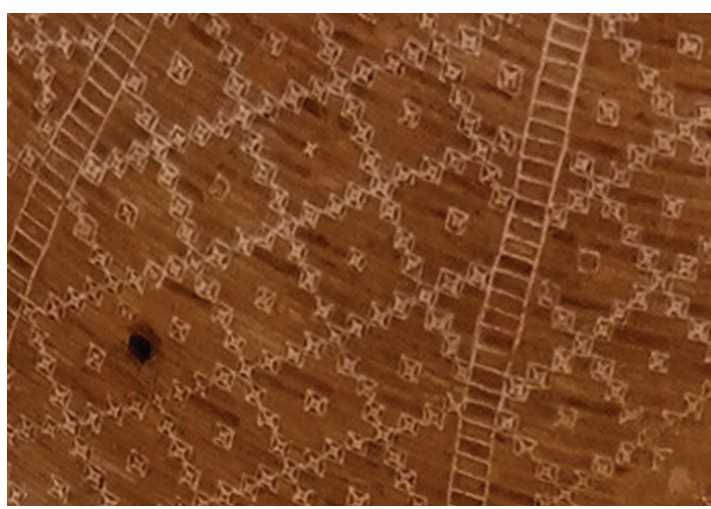

Resim 52. Ardistân Cuma Camii Alçı Derz Süslemeleri

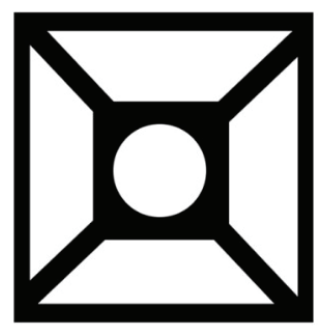

Çizim 32. Ardistân Cuma Camii Alçı Derz Süslemeleri (Azizpour’dan) 


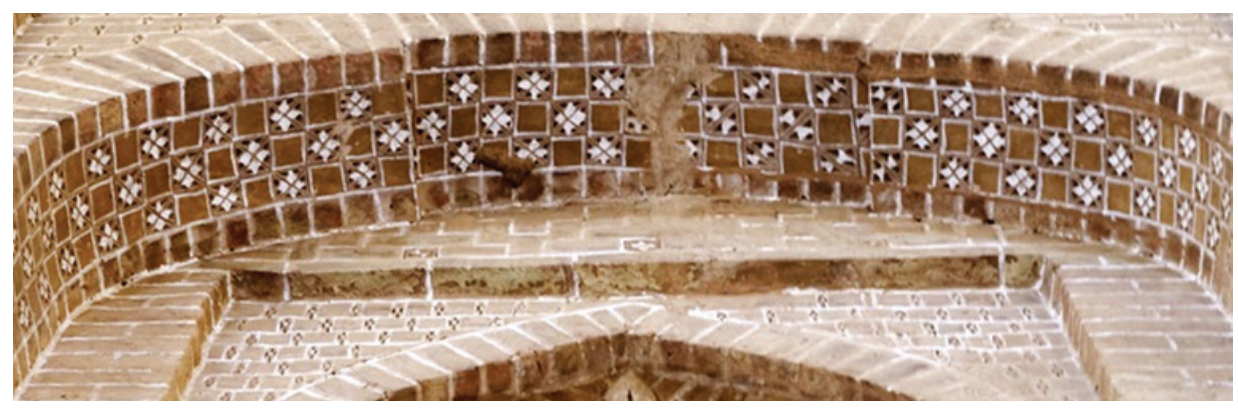

Resim 53. Ardistân Cuma Camii Alçı Derz Süslemeleri

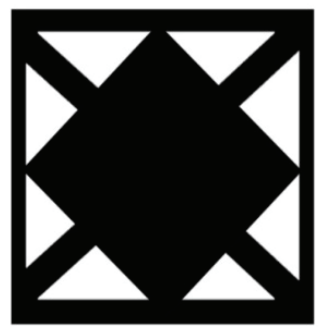

Çizim 33. Ardistân Cuma Camii Alçı Derz Süslemeleri (Azizpour'dan)

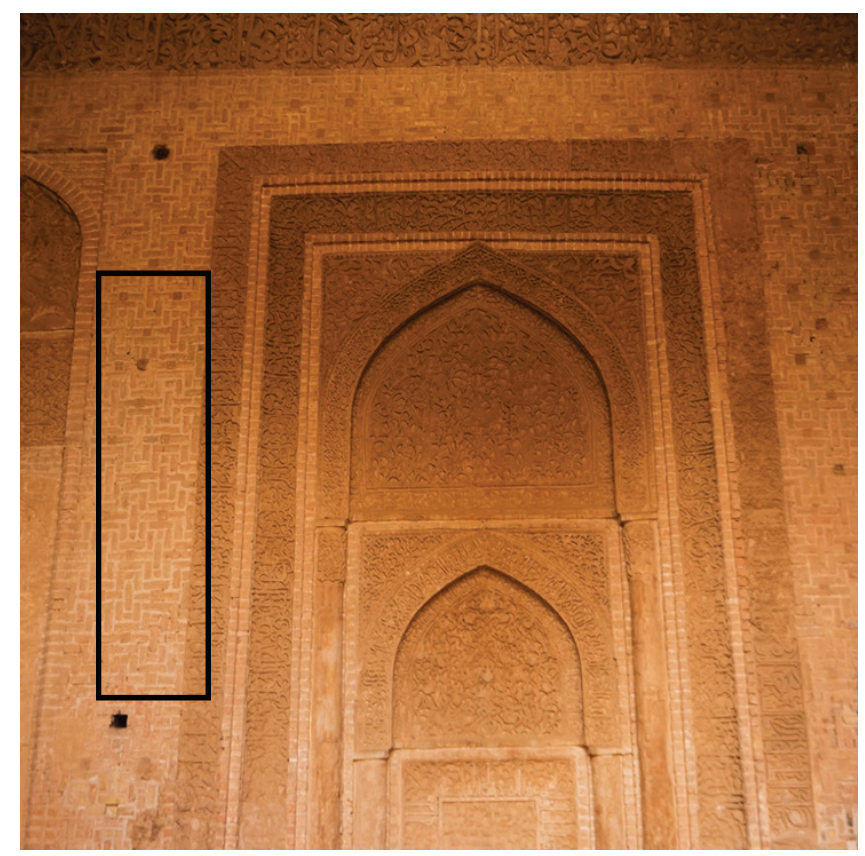

Resim 54. Ardistân Cuma Camii Alçı Derz Süslemeleri 


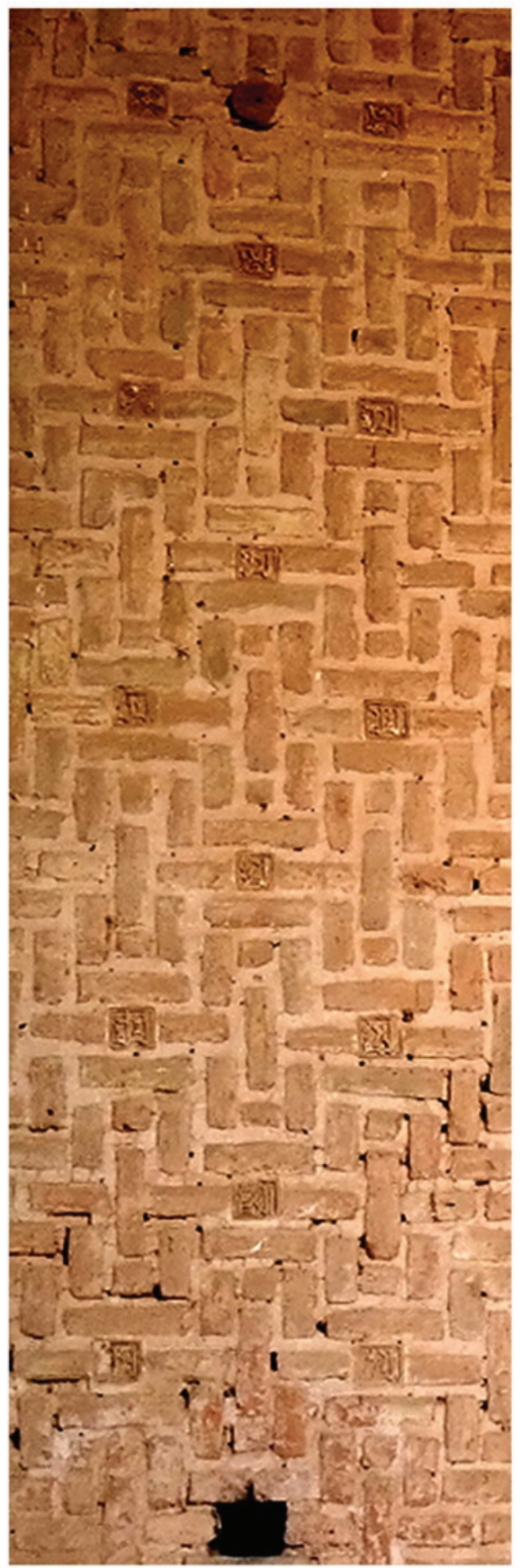

Resim 55. Ardistân Cuma Camii Alçı Derz Süslemeleri 

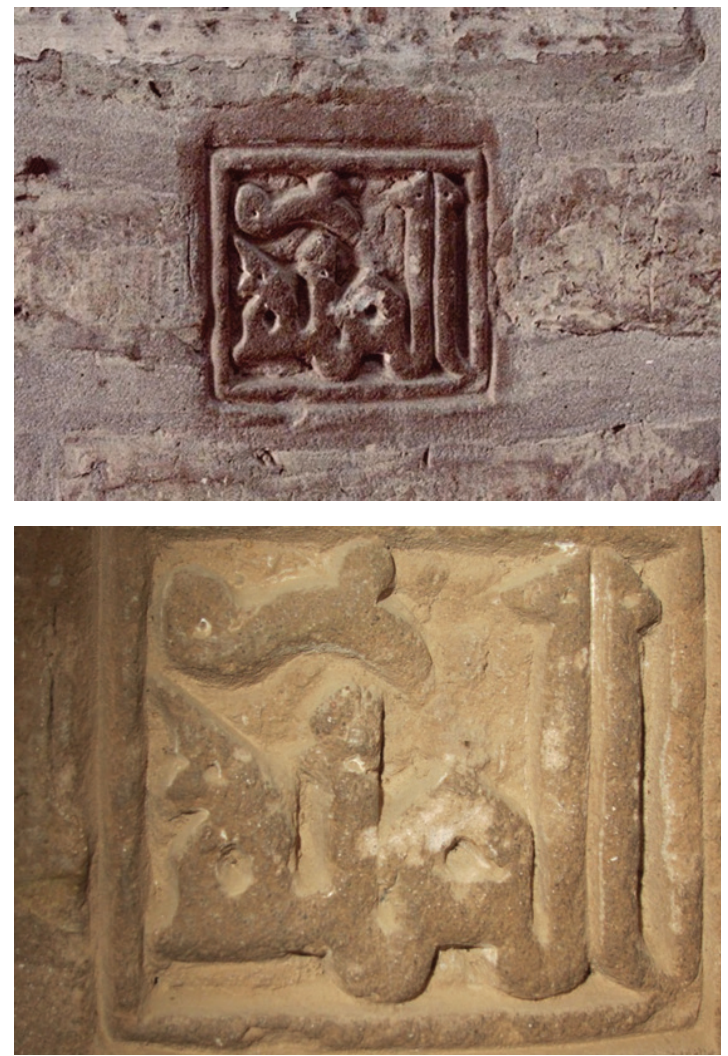

Resim 56. Ardistân Cuma Camii Alçı Derz Süslemeleri

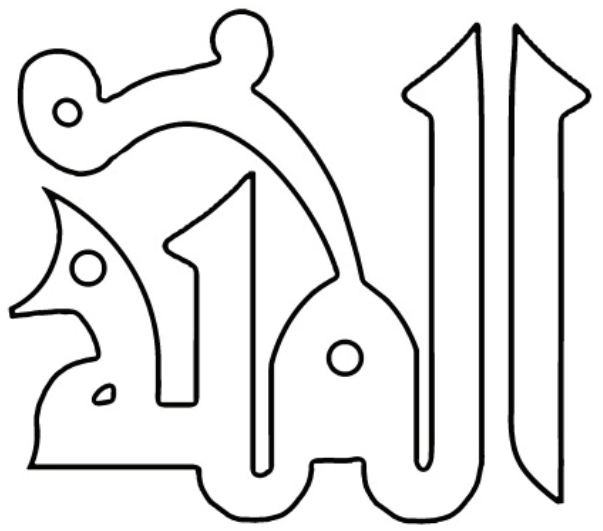

Çizim 34. Ardistân Cuma Camii Alçı Derz Süslemeleri (Azizpour'dan) 
Tablo 1. Ardistân Cuma Camii Mihrabındaki Süslemelerin Diğer Dönemlere Ait Süslemeler ile Karşılaştırılması

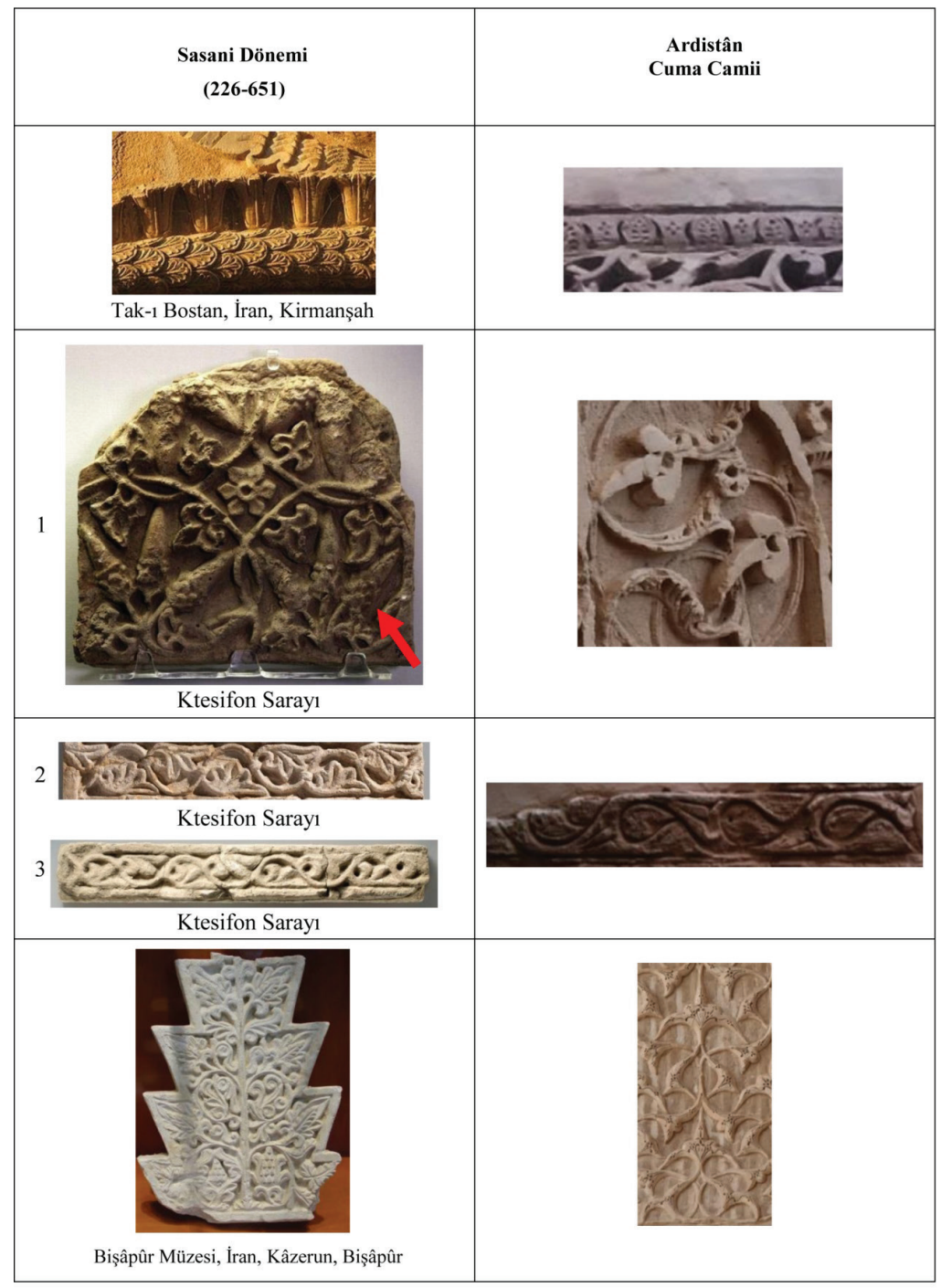

\section{Numaralandırılmış Resimlerin Kaynağı:}

1- https://www.kavehfarrokh.com/military-history-1900-present/jens-krogerctesiphon/

2- https://www.metmuseum.org/art/collection/search/322639

3- https://www.metmuseum.org/art/collection/search/322673 
Tablo 2: Ardistân Cuma Camii Mihrabındaki Süslemelerin Diğer Dönemlere Ait Süslemeler ile Karşılaştırılması

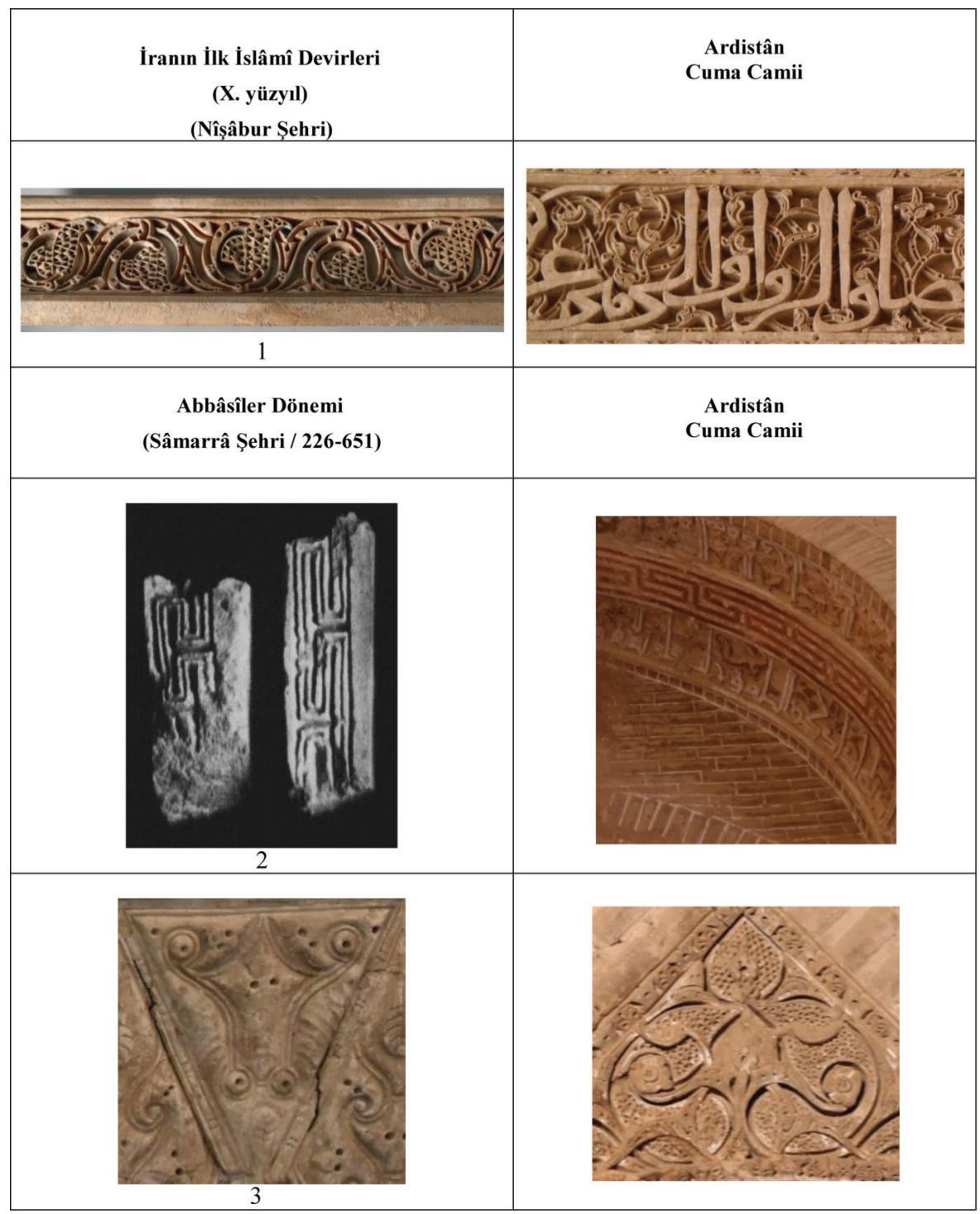

\section{Numaralandırılmış Resimlerin Kaynağı:}

1- https://www.metmuseum.org/art/collection/search/449951

2- Herzfeld, Ernst. Die Ausgrabungen von Samarra, Band VI, Geschichte der Stadt Samarra, (Verlag von Sachardt\&Messtorff, 1948)

3- https:/universes.art/en/art-destinations/berlin/museum-of-islamic-art/photo-tour/ samarra-wall-coverings 
Tablo 3: Ardistân Cuma Camii Mihrabındaki Süslemelerin Diğer Dönemlere Ait Süslemeler ile Karşılaştırılması

\begin{tabular}{|c|c|c|}
\hline & Ardistân \\
Cuzneliler Dönemi \\
(963-1186)
\end{tabular}

\section{Numaralandırılmış Resimlerin Kaynağı:}

1- http://www.unesco.org/culture/museum-for-dialogue/item/en/216/glazedhexagonal-moulded-tile 2- https://archnet.org/sites/3923/media_contents/144310

3- https://unora.unior.it/retrieve/handle/11574/160922/61920/Filigenzi\%20 Giuntat\%20Afghanistan.pdf

4-Wilkinson, Charles J. (1986). Nishapur: Some Early Islamic Buildings and Their Decoration. New York: The Metropolitan Museum of Art. 
Tablo 4. Ardistân Cuma Camii Mihrabındaki Süslemelerin Diğer Dönemlere Ait Süslemeler ile Karşılaştırılması

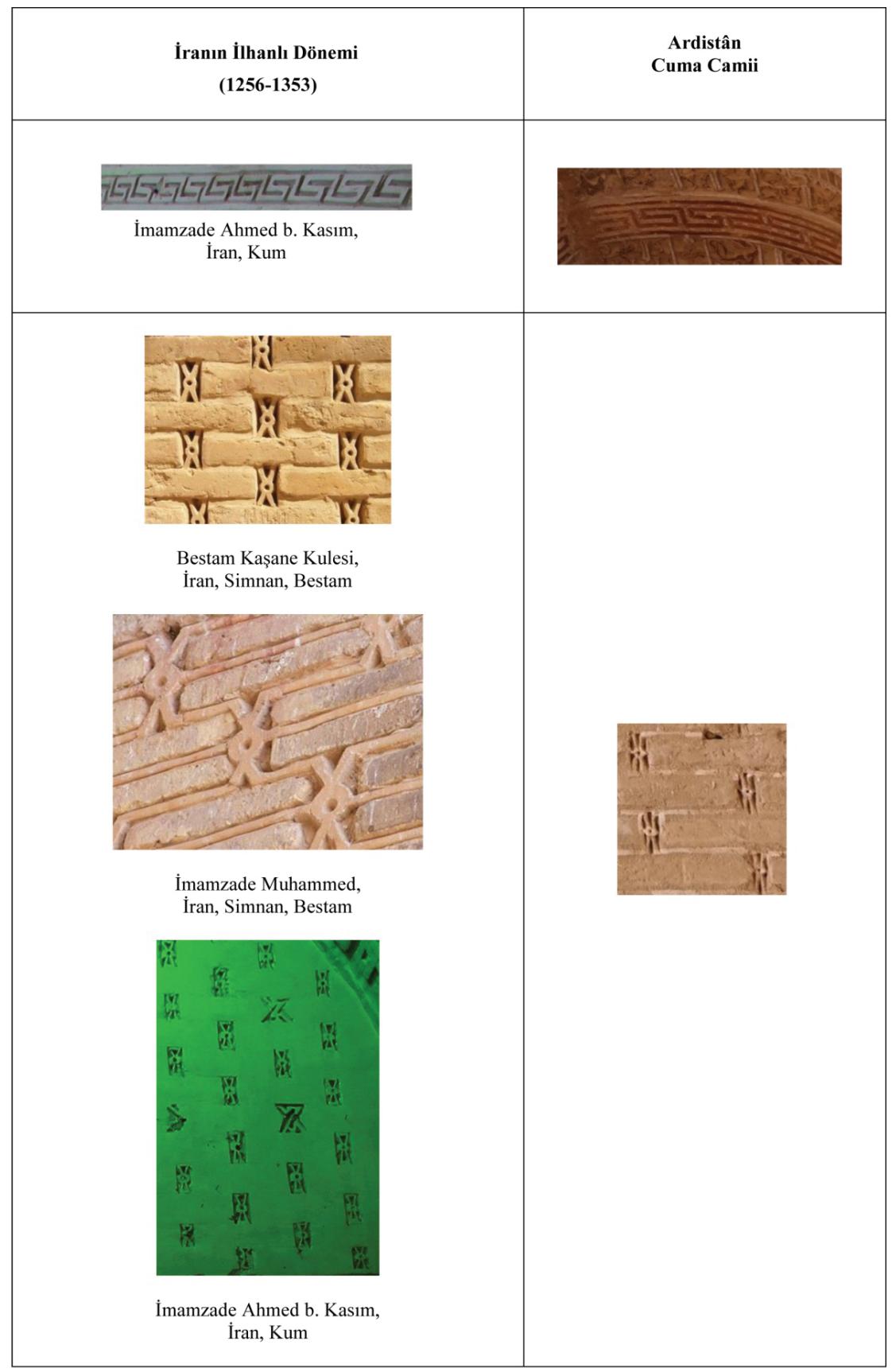


Tablo 5. Ardistân Cuma Camii Mihrabındaki Süslemelerin Diğer Dönemlere Ait Süslemeler ile Karşılaştırılması

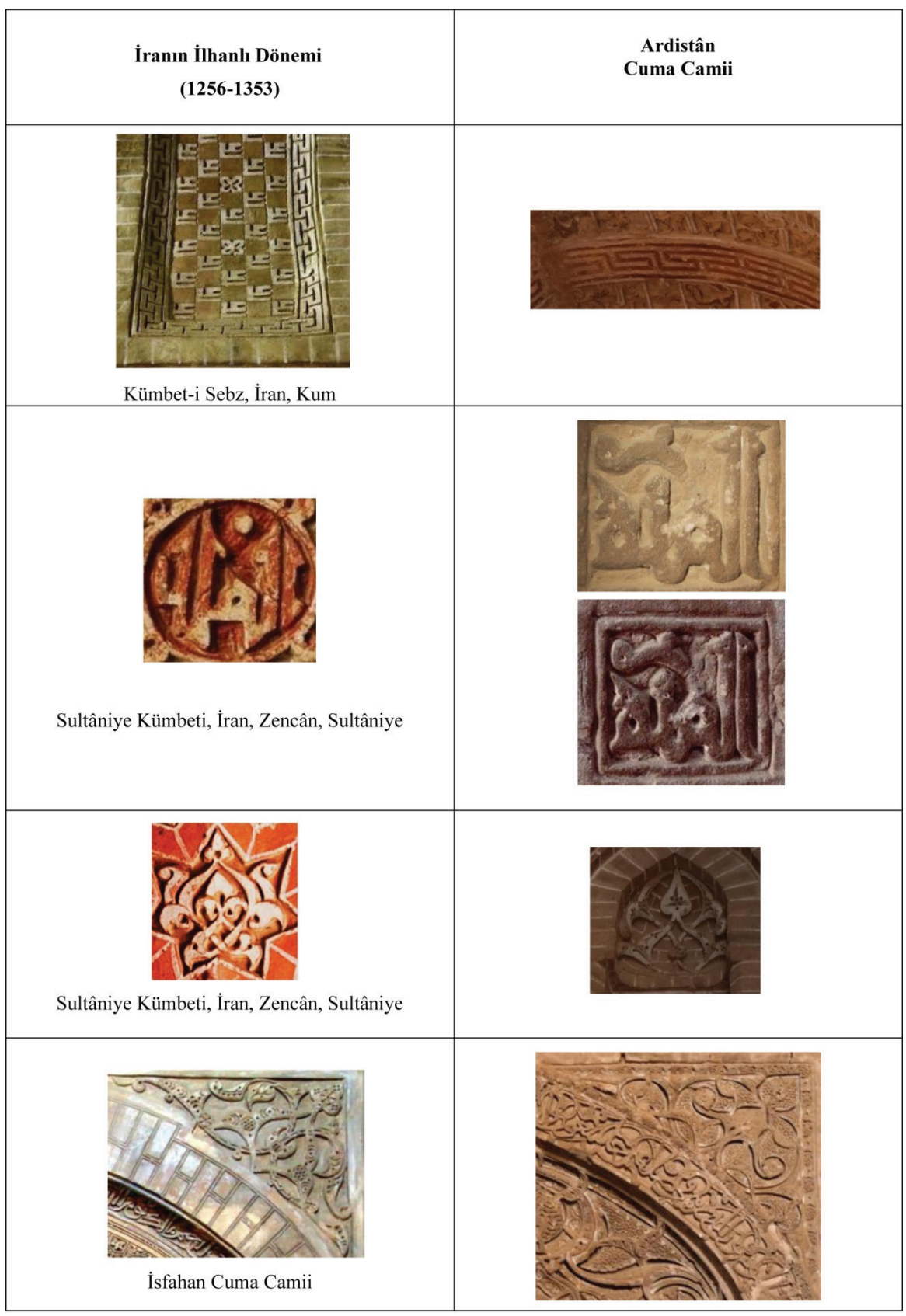


Tablo 6. Ardistân Cuma Camii Mihrabındaki Süslemelerin Diğer Dönemlere Ait Süslemeler ile Karşılaştırılması

\begin{tabular}{|c|c|c|}
\hline Iranin Illhanh Dönemi & Ardistân \\
Cuma Camii
\end{tabular}

\section{Numaralandırılmış Resimlerin Kaynağı:}

1-https://seyahatdergisi.com/sahabiye-medresesi-nerede-tarihi-ve-hakkinda-bilgi/ 
Tablo 7. Ardistân Cuma Camii Mihrabındaki Süslemelerin Diğer Dönemlere Ait Süslemeler ile Karşılaştırılması

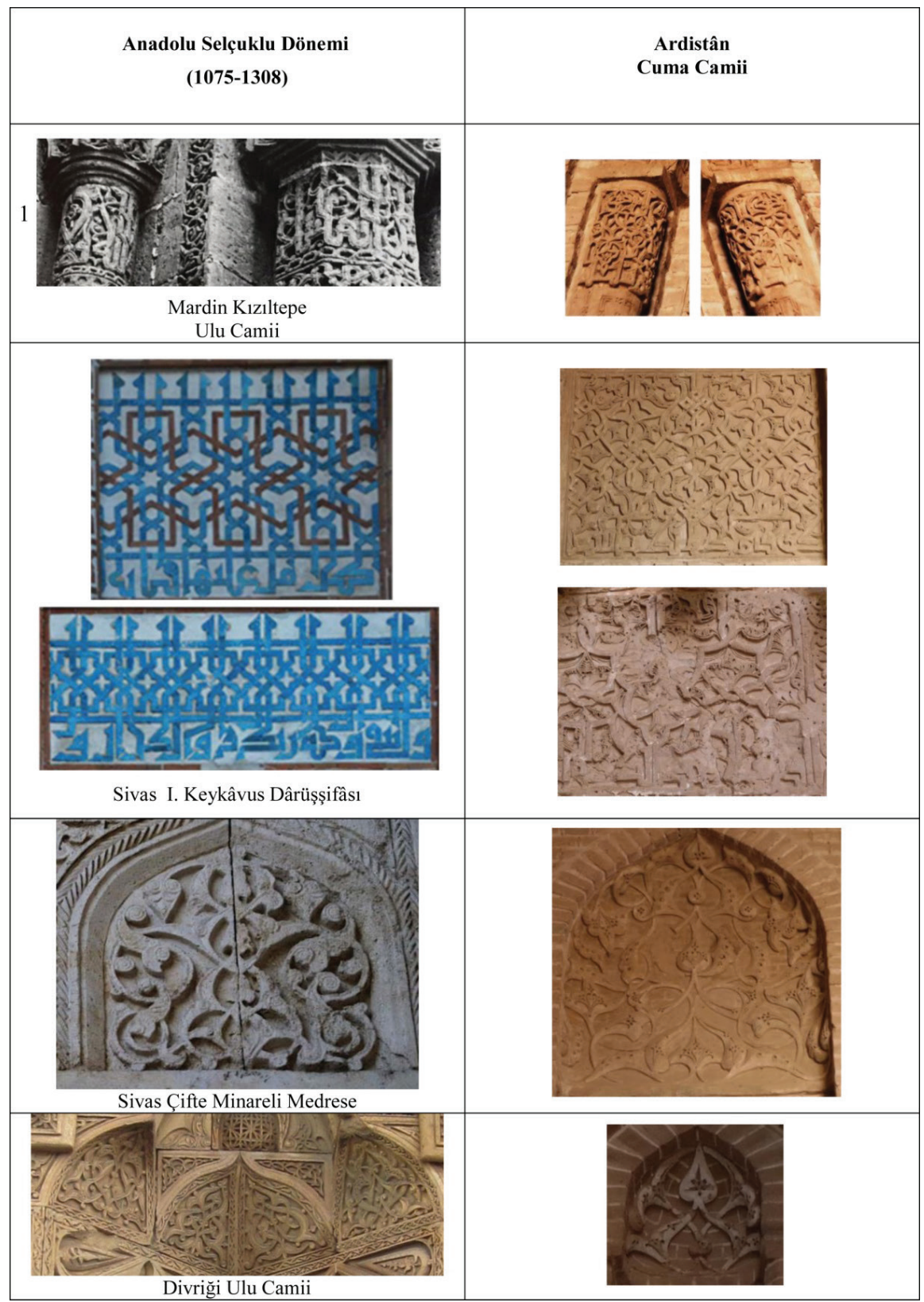

\section{Numaralandırılmış Resimlerin Kaynağı:}

1- https://scontent.ftzx 1-1.fna.fbcdn.net/v/t1.0-9/ 
Tablo 8. Ardistân Cuma Camii Mihrabındaki Süslemelerin Diğer Dönemlere Ait Süslemeler ile Karşılaştırılması

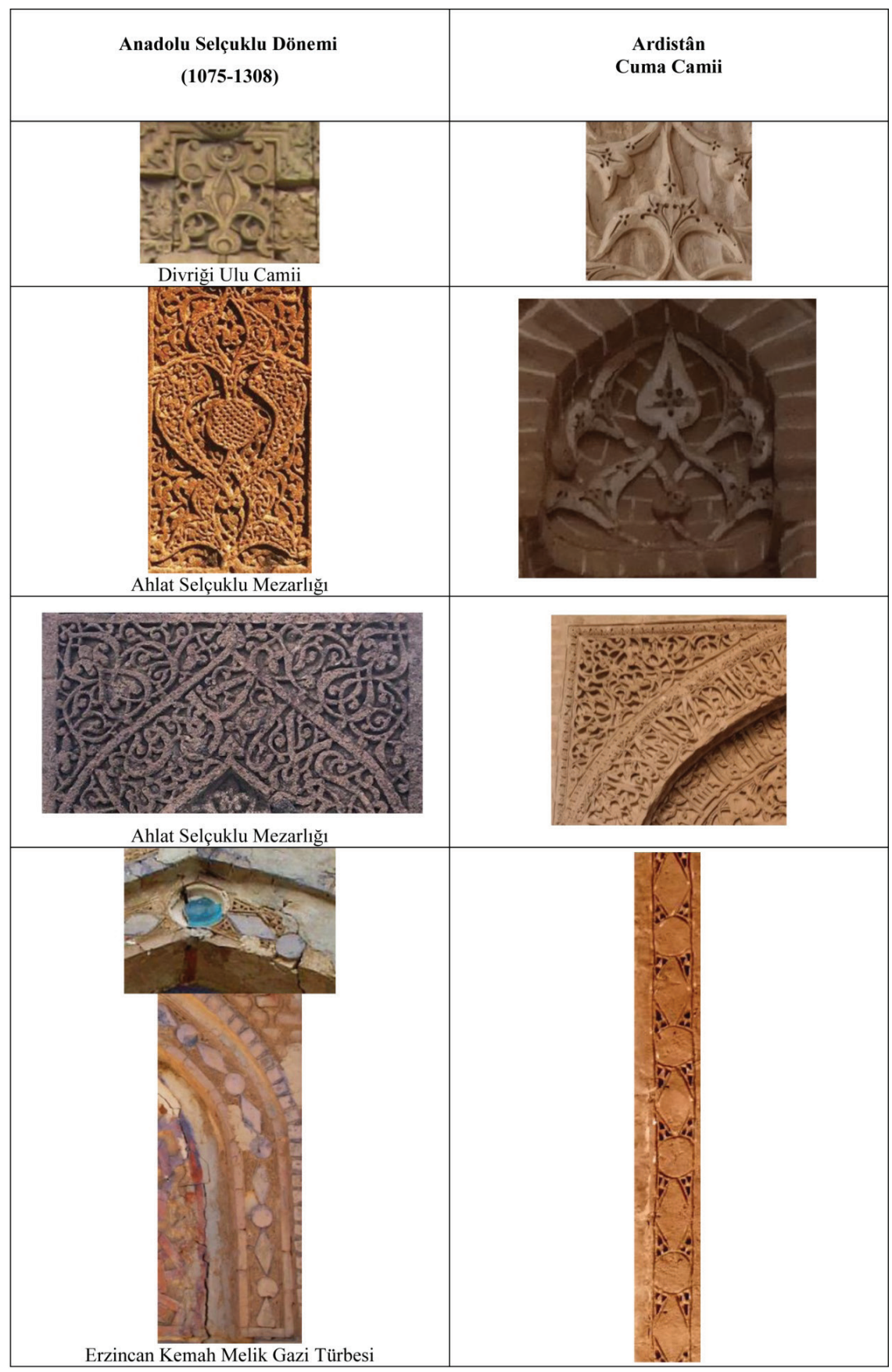


Tablo 9. Ardistân Cuma Camii Mihrabındaki Süslemelerin Diğer Dönemlere Ait Süslemeler ile Karşılaştırılması

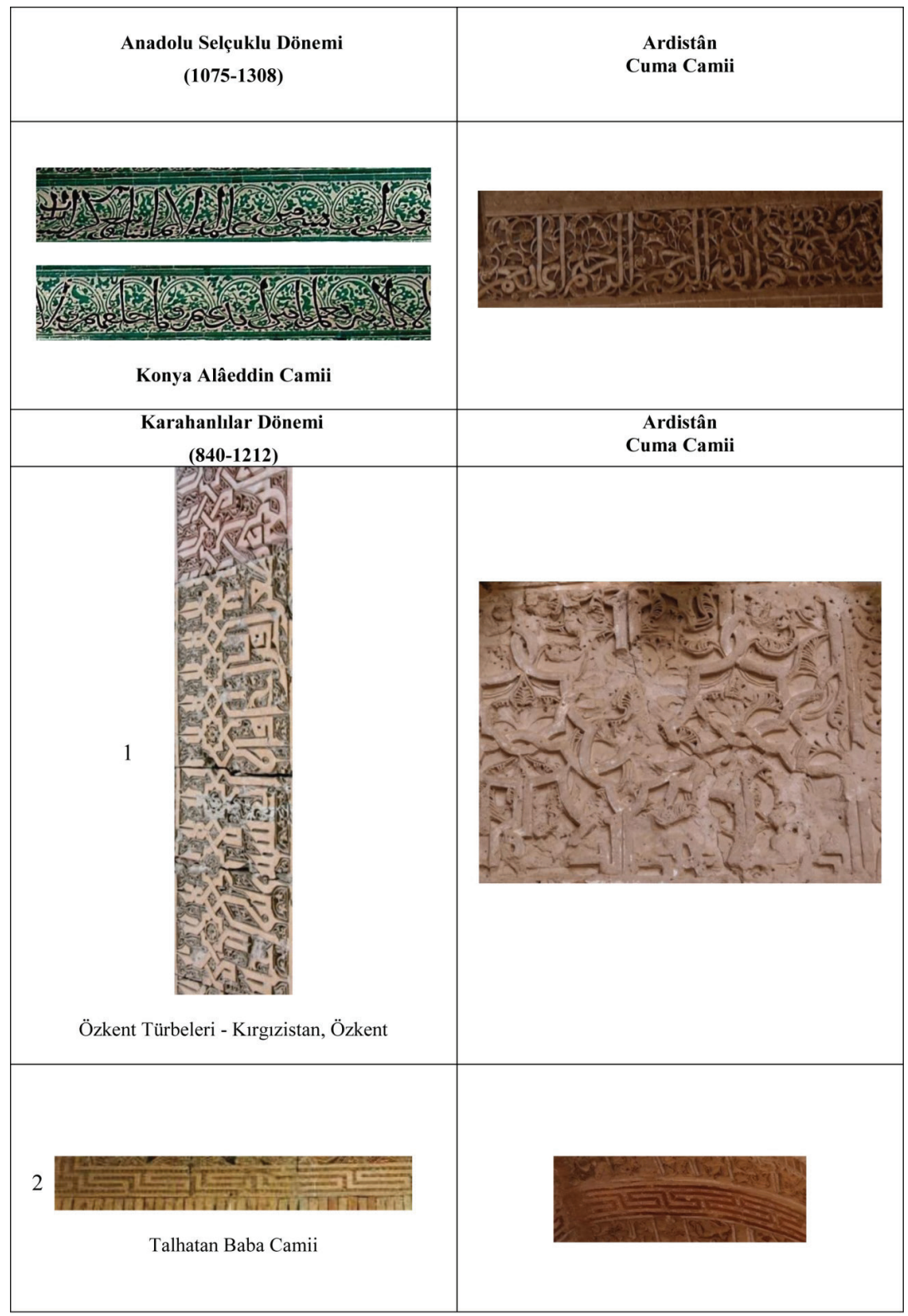

\section{Numaralandırılmış Resimlerin Kaynağı:}

1- http://www.photo.kg/uploads/posts/2015-08/1439989994_img_2535.jpg

2- http://www.photo.kg/uploads/posts/2015-08/1439989994_img_2535.jpg 

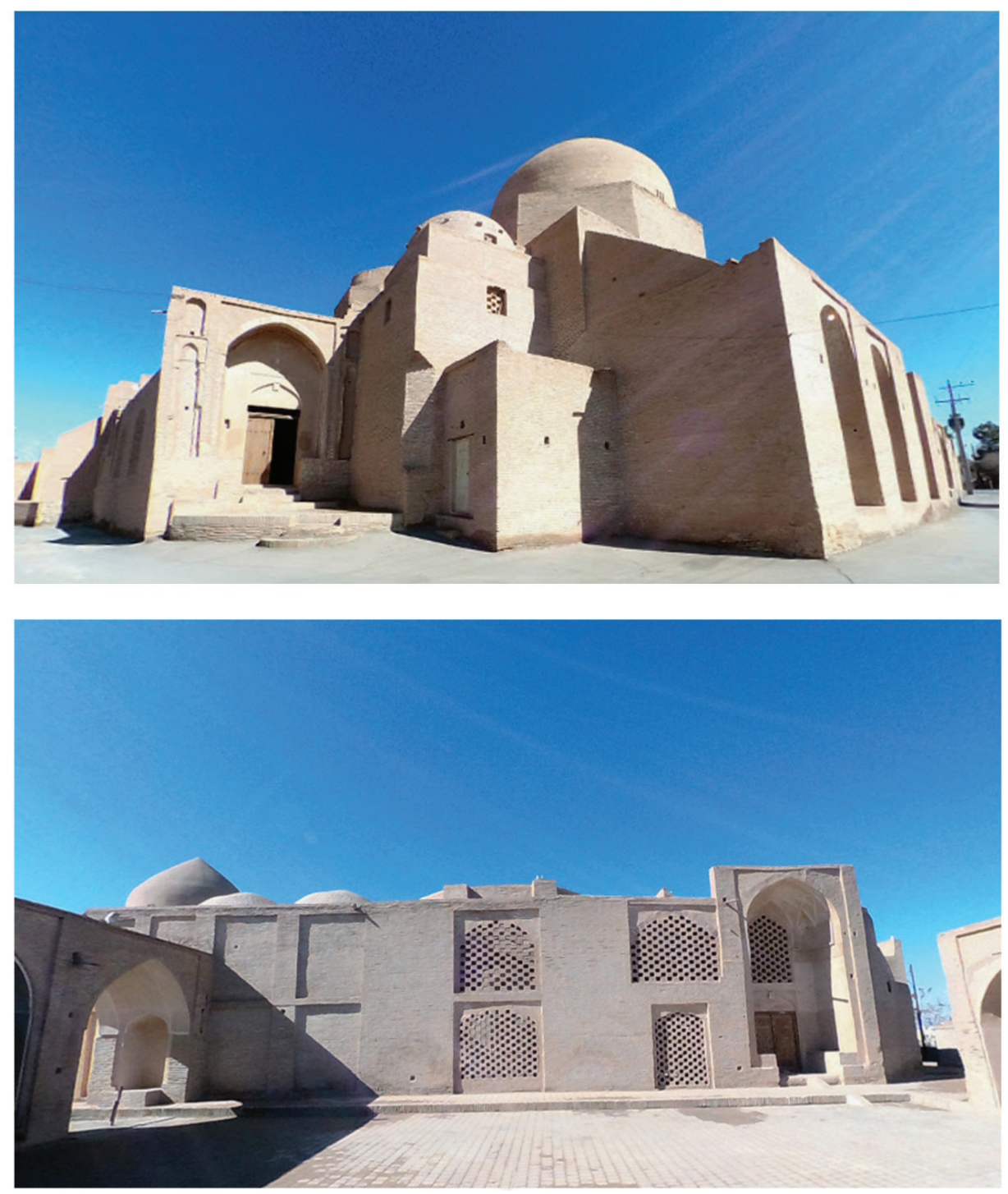

Resim 57. Ardistân Cuma Camii’nin Dış Cepheleri 
Plan 1. Ardistân Cuma Camii’nin Planı

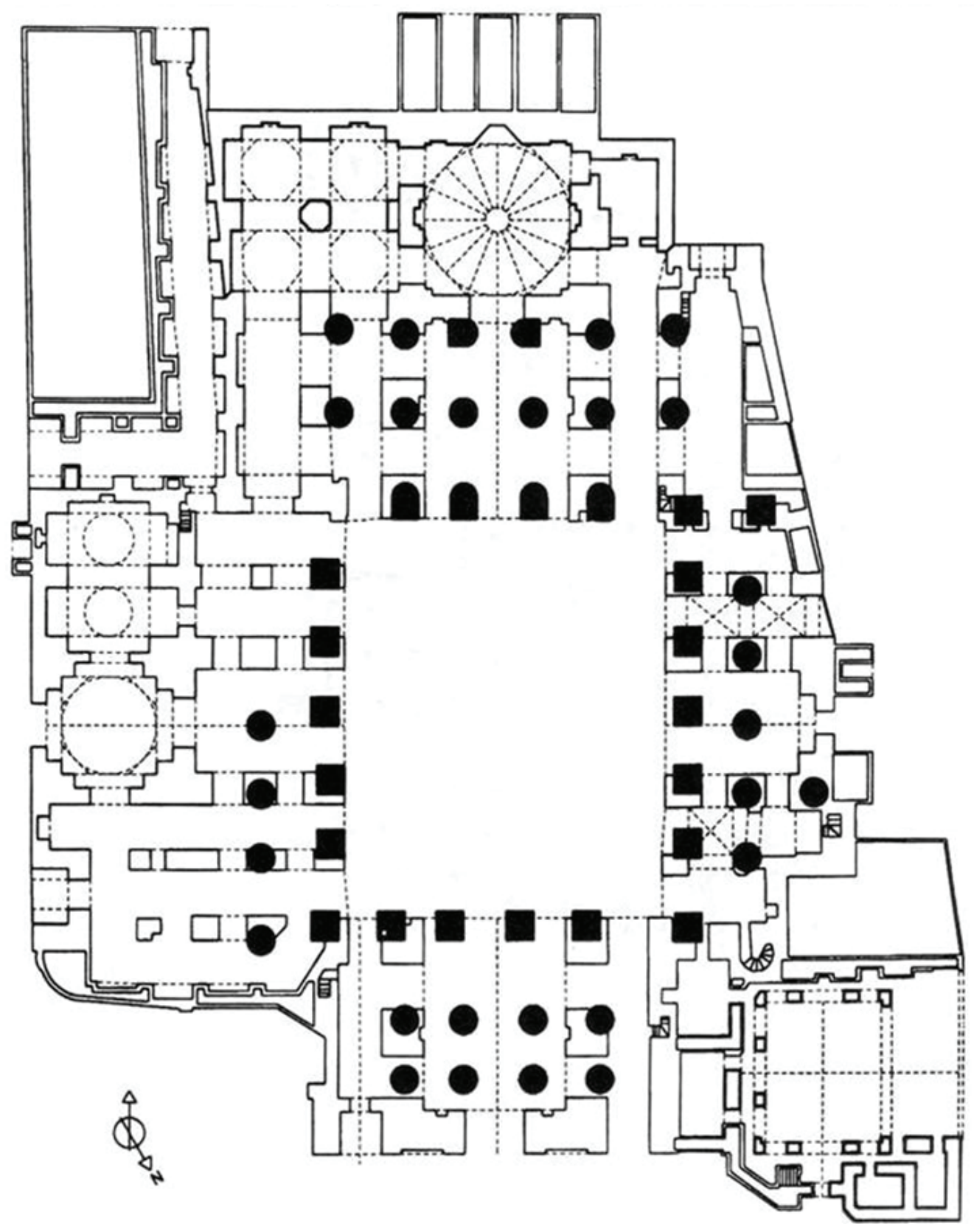

Kaynak: İran Kültürel Miras, El Sanatları ve Turizm Kurumu Arşivi 
